\title{
Verbindende perspectieven voor een duurzaam landelijk gebied
}

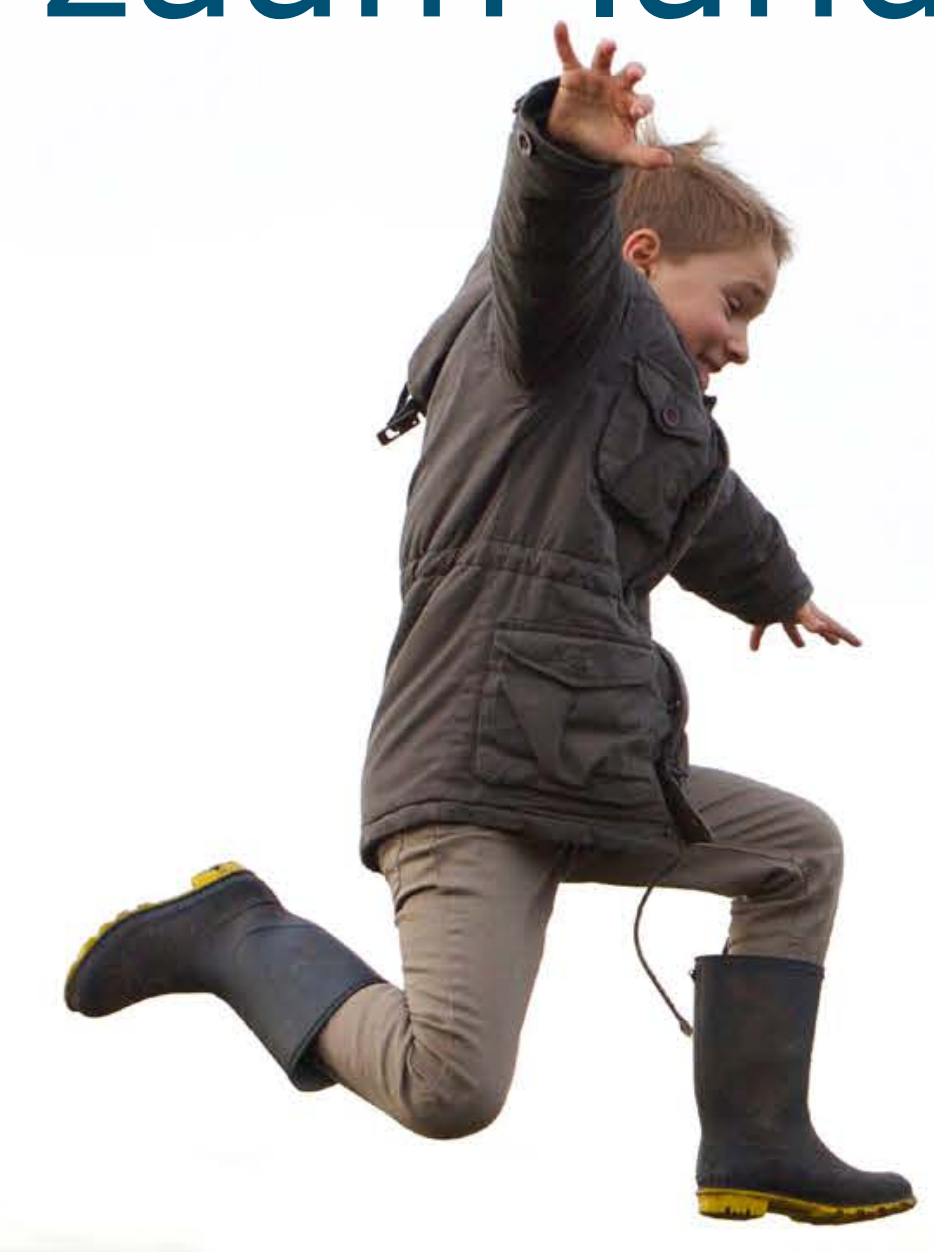

Inhoud

Introductie

Vier toekomstperspectieven Handelingsopties Handreiking Vergelijking toekomstperspectieven Colofon

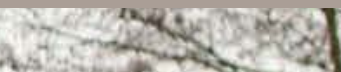

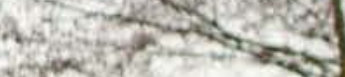




\section{Vier toekomstperspectieven om de samenhangende verduurzamingsopgaven}

te realiseren

In het landelijk gebied komen veel beleidsthema's samen. Op alle thema's is verdere verduurzaming nodig om de lange termijn doelen te halen. Om het landelijk gebied van Overijssel richting 2050 verder te verduurzamen, moet de provincie oplossingen vinden voor vijf samenhangende opgaven. De ambitie van de provincie is om deze opgaven in samenhang op te pakken. Welke keuzes zijn daarbij mogelijk? En wat betekenen deze keuzes voor de invulling van opgaven? In deze verkenning beantwoorden we deze vragen. We hebben vier toekomstperspectieven uitgewerkt. Deze scenario's geven inzicht hoe Overijssel er in 2050 uit kan zien bij verschillende invullingen van de samenhangende opgaven.

\section{Samenhangende opgaven als vertrekpunt voor toekomstscenario's}

Deze brochure beschrijft het tweede deel van een strategische verkenning. In drie fasen wordt toewerkt naar verschillende handelingsopties voor de verduurzaming van het landelijk gebied van Overijssel richting 2050. De eerste fase bestond uit een analyse: welke doelen zijn gesteld en worden die gehaald? Deze analyse gaf inzicht in de opgaven waar we voor staan om te verduurzamen. Hieruit zijn vijf samenhangende opgaven naar voren gekomen voor de verduurzaming van het landelijk gebied van Overijssel.

De eerste conclusie op basis van de analyse uit fase I is dat voortzetting van het huidige beleid tot gevolg heeft dat een aantal doelen niet gehaald worden en dat een aantal trends, zoals klimaatverandering, ervoor zorgen dat het doelbereik eerder verder weg dan dichtbij komt. In de brochure "Analyse verduurzamingsopgaven landelijk gebied' is te lezen voor welke doelen dat geldt en hoe de vijf samenhangende opgaven tot stand gekomen zijn.
De tweede conclusie op basis van de analyse uit fase I is dat de samenhangende opgaven niet met bestaand beleid opgelost kunnen worden. De eerder geschetste samenhangende opgaven voor het landelijk gebied van Overijssel zijn zo groot dat doorgaan op de huidige weg geen optie is. Het lukt eenvoudigweg niet om deze opgaven te vervullen binnen de huidige systemen (stelsels van dominante praktijken en regels die het handelen van actoren beïnvloeden). Innovatieve ideeën zijn nodig om deze bestaande structuren en patronen te doorbreken. Voor het landelijk gebied gaat het om systeeminnovaties op het gebied van "Landbouw \& Voedsel", "Klimaat \& Energie" en "Natuur \& Biodiversiteit". We zien daarbij de verwachte klimaatverandering en de mondiale inzet om deze te temperen en ons hierop aan te passen als een belangrijke aanjager van deze systeeminnovaties.
Inhoud

Introductie

Vier toekomstperspectieven

Handelingsopties

Handreiking

Vergelijking

toekomstperspectieven

Colofon 
Vijf belangrijke samenhangende opgaven

De resultaten van deze eerste fase vormden het startpunt voor fase II: het ontwerpen van verbindende perspectieven voor het landelijk gebied van 2050. Bij het ontwerpen van elk scenario was het uitgangspunt dat alle opgaven worden vervuld door de systeem- innovaties op verschillende wijze in te vullen. Achterin deze brochu-

re staat een overzicht van de wijze waarop de vier scenario's

bijdragen aan het realiseren van de samenhangende opgaven.

\section{Ruimtelijke kwaliteit realiseren door transformatie naar klimaat- bestendige landschappen}
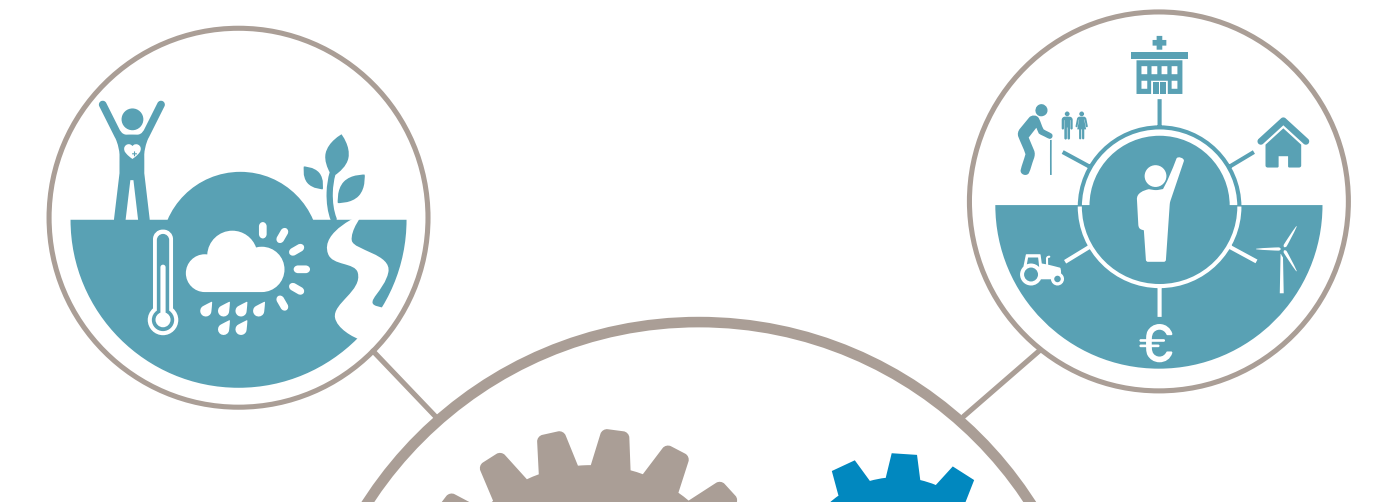

Verbinden van opgaven aan versterken sociale kwaliteit en transformatie regionale economie

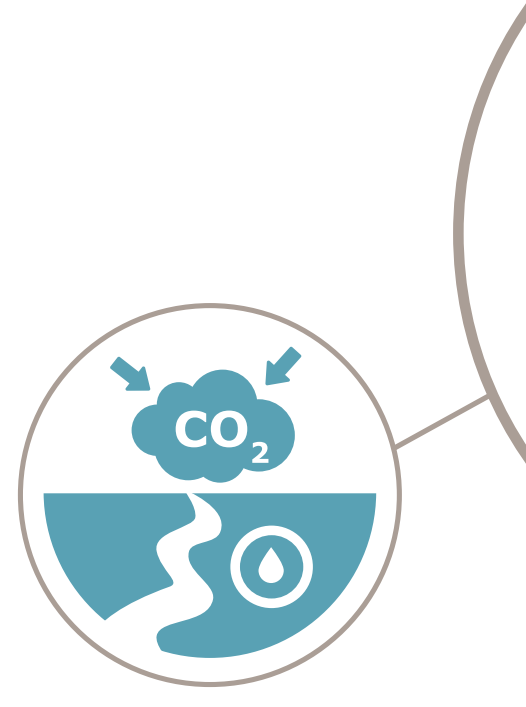

Emissies milieubelastende stoffen zover terugdringen dat ze andere functies niet beperken

\section{Inhoud}

Introductie

Vier toekomstperspectieven

Handelingsopties

Handreiking

Vergelijking

toekomstperspectieven

\section{Colofon}




\section{Keuze voor doelscenario's}

Doel van deze verkenning is om voorafgaand aan het maken van beleidskeuzes, de verschillende verwachtingen en wensen over de toekomst uit te wisselen en hierop te reflecteren. Scenario's kunnen daarbij helpen. Met toekomstscenario's bereiden we ons voor op een nog onbekende toekomst. Dat kan op twee manieren (Vrije vertaling naar Dammers et al. 2013'1).

De eerste manier is om centraal stellen welke ontwikkelingen niet zijn te beïnvloeden. De grootste onzekerheden bepalen dan de uiteenlopende scenario's. Dit worden ook wel omgevingsscenario's genoemd. Een andere manier is: centraal stellen wat de grootste toekomstige dilemma's zijn als je een gewenst doel wilt bereiken en

\section{Scenario's uitgewerkt in ateliers}

Circa 30 mensen met verschillende achtergronden (bedrijven en bewoners van het landelijk gebied in Overijssel) werkten in ontwerpateliers samen vier scenario's uit. Dat deden ze op persoonlijke titel. Ze zochten naar principes en mechanismen die een oplossing bieden voor de vijf samenhangende opgaven. Dit leidde tot vier verbindende perspectieven voor beleid en samenleving. Vervolgens reflecteerden partners van Samen Werkt Beter, provinciale beleidsambtenaren en verschillende experts op de vier scenario's. Daarbij stond steeds de vraag centraal: "Kunnen de voorgestelde principes werken en realiseren we daarmee de opgaven?" welke keuzes je kunt maken. Dit gaat over zaken waar je wel invloed op hebt. Deze vorm van scenario's worden doelscenario's genoemd.

In deze verkenning werken we met doelscenario's. Uitgangspunt is dat overheid en samenleving invloed hebben op de manier waarop je beleidsdoelen bereikt en de wijze waarop samenhangende opgaven gerealiseerd gaan worden. De scenario's zijn geen reële werkelijkheden of mogelijke eindstations, maar bieden inspiratie voor een verder gesprek over de gewenste ontwikkelingsrichting voor het landelijk gebied.

Dit leidde tot vier uitgewerkte scenario's voor verduurzaming van het landelijk gebied. In elk scenario worden de verduurzamingsopgaven voor het landelijk gebied op verschillende manieren gerealiseerd. De toekomstperspectieven zijn echter niet tot in de details uitgewerkt. We kunnen dus ook niet exact doorrekenen of daarmee de doelen gehaald worden.

De opmerkingen uit de reflectiebijeenkomsten zijn gebruikt om de beschrijving van de perspectieven aan te vullen of aan te scherpen. Belemmeringen die gesignaleerd werden om tot een toekomstperspectief te komen, zijn verwerkt in het hoofdstuk waarin handelingsperspectieven om richting een scenario te bewegen zijn beschreven.

\section{Van dilemma's naar toekomstperspectieven in doelscenario's}

Bij de start van de ontwerpateliers is gezocht welke dilemma's er spelen rond de verduurzamingsopgaven voor het landelijk gebied richting 2050. Uit alle dilemma's die op tafel kwamen, zijn uiteindelijk twee grootste dilemma's naar voren gekomen:
- Welk systeem is uitgangspunt van ons handelen? Het technologisch systeem of het natuurlijk systeem?

- Welke sturing kiezen we en wie neemt initiatief? Doet de samenleving dat of de overheid?

1 Dammers, E., S. Klooster, B. de Wit, H. Hilderink, A. Petersen \& W. Tuinstra, 2013. Scenario's maken voor milieu, natuur en ruimte: een handreiking. Den Haag: Planbureau voor de Leefomgeving.

Introductie

Vier toekomstperspectieven

Handelingsopties

Handreiking

Vergelijking

toekomstperspectieven

Colofon 
Het eerste dilemma gaat over de keuze hoe je om kunt gaan met het natuurlijke systeem van bodem, water en biodiversiteit. Je kunt enerzijds kiezen voor dit natuurlijke systeem als uitgangspunt, waarbij je het benut en versterkt door binnen de grenzen van dat systeem te werken. Deze variant leidt tot een veerkrachtig natuurlijk systeem. Menselijk handelen maakt gebruik van dat systeem zonder de veerkracht aan te tasten.

Anderzijds kun je kiezen voor een technologisch systeem waarbij je kiest voor maakbaarheid als uitgangspunt. Daarbij staat het (technologisch) beheersen en ingrijpen op het natuurlijke systeem centraal. Als in dit systeem de doelen uit zicht raken, wordt technisch ingegrepen om ze alsnog te halen.
Het tweede dilemma gaat over de vraag wie het initiatief neemt. Dat kan de overheid zijn, die vervolgens aan de samenleving vraagt om invulling. Of het initiatief ligt in eerste instantie bij de samenleving waarbij de overheid met name faciliteert en stimuleert. Dit leidt tot de volgende twee varianten:

- De overheid neemt het initiatief en vraagt de samenleving in te vullen; de overheid stelt kaders, maar stuurt ook sterk op de wijze waarop daaraan invulling wordt gegeven.

- De overheid stelt kaders, maar vult die niet in. De samenleving neemt verder initiatief en volbrengt opgaven binnen die kaders.

Door deze twee dilemma's met elkaar te kruisen, ontstaan vier kwadranten als vertrekpunt voor vier scenario's. Voor elk kwadrant zijn onderscheidende principes beschreven, die aan de basis staan van de vier perspectieven.

\section{Introductie}

Vier toekomstperspectieven

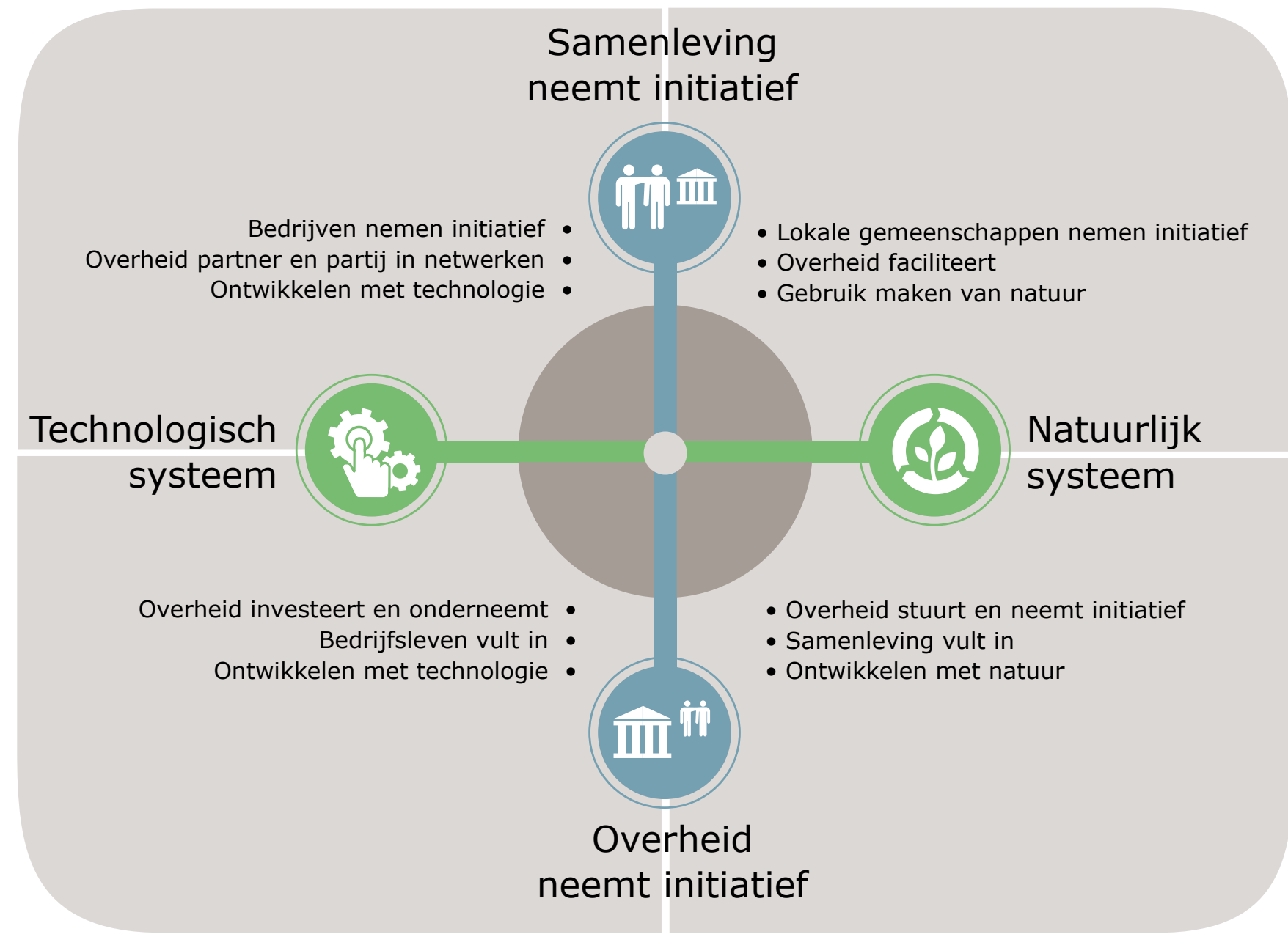


In de uitwerking van de vier scenario's hebben we geprobeerd de uiterste hoeken van de kwadranten op te zoeken en daarmee het onderscheid tussen de scenario's zo groot mogelijk te maken. De bedoeling daarvan is om de oplossingsruimte zo groot mogelijk te maken door de denkruimte zoveel mogelijk op te rekken en het bewustzijn te vergroten. Belangrijk daarbij is dat de beelden voorstelbaar zijn. De beelden moeten daarvoor:

1 relevant zijn (voor impact zorgen en de urgentie voor provincie en partners raken);

2 radicaal zijn (dominant denken doorbreken en nieuwe inzichten bieden);

3 plausibel zijn (consistent zijn en aansluiten bij de trends).
Dat wil niet zeggen dat deze perspectieven helemaal wetenschappelijk doorwrocht zijn. De perspectieven geven vooral kwalitatief beeld over de wijze waarop opgaven in samenhang kunnen worden gerealiseerd. Ze zijn niet doorgerekend of gekwantificeerd. De mate waarin de samenhangende opgaven volbracht worden, valt of staat namelijk met hoe de principes verder uitgewerkt gaan worden. Zo wordt steeds gesproken over 'de' overheid, maar deze is nog niet nader gespecificeerd. Dit kan, afhankelijk van de bevoegdheden en zeggenschap, verschillen van EU tot gemeenten. In de meeste gevallen betreft het hier de regionale overheid (provincie, waterschappen, gemeenten).

\section{Geen toekomstvoorspelling, wel een bron van inspiratie voor beleidskeuzes}

In elk doelscenario is een aantal principes en mechanismen uitgewerkt om oplossingen te vinden voor de samenhangende opgaven. Daarmee zijn de perspectieven geen scenario's waarvoor je kunt kiezen, maar een inspiratiebron voor deze mechanismen. Hoe zouden ze kunnen werken? En wat betekent dit voor onze economie? Hebben we misschien anders geschoolde arbeidskrachten nodig? Of wat doet een uitwerking met de (on)gelijkheid in de samenleving? Dat zijn terechte vragen die de beschrijving van de perspectieven oproepen. Het antwoord staat niet in deze brochure. Simpelweg omdat alleen de uiteindelijke beleidskeuzes en de exacte uitwerking het antwoord op deze vragen kunnen geven.

Wel bieden de vier scenario's handvatten om met elkaar na te denken over beleidskeuzes en handelingsopties voor verduurzaming van het landelijk gebied, daar het politieke en maatschappelijke debat over te voeren en vervolgstappen te zetten.
Inhoud

\section{Introductie}

Vier toekomstperspectieven

Handelingsopties

Handreiking

Vergelijking

toekomstperspectieven

\section{Colofon}




\section{Vier toekomstperspectieven}

Samenleving neemt initiatief

\section{Marktgedreven Overijssel}

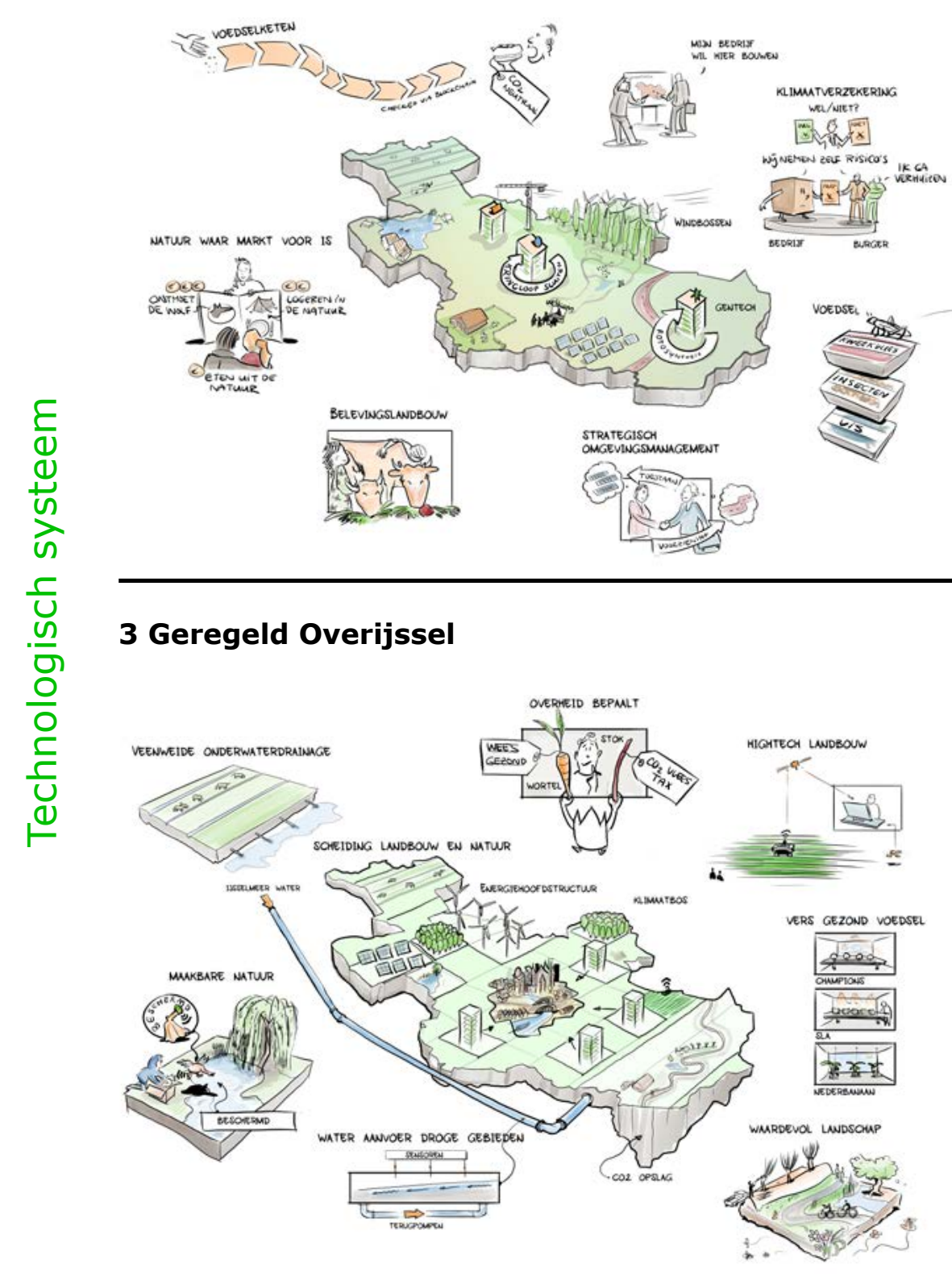

2 Samenwerkend Overijsse

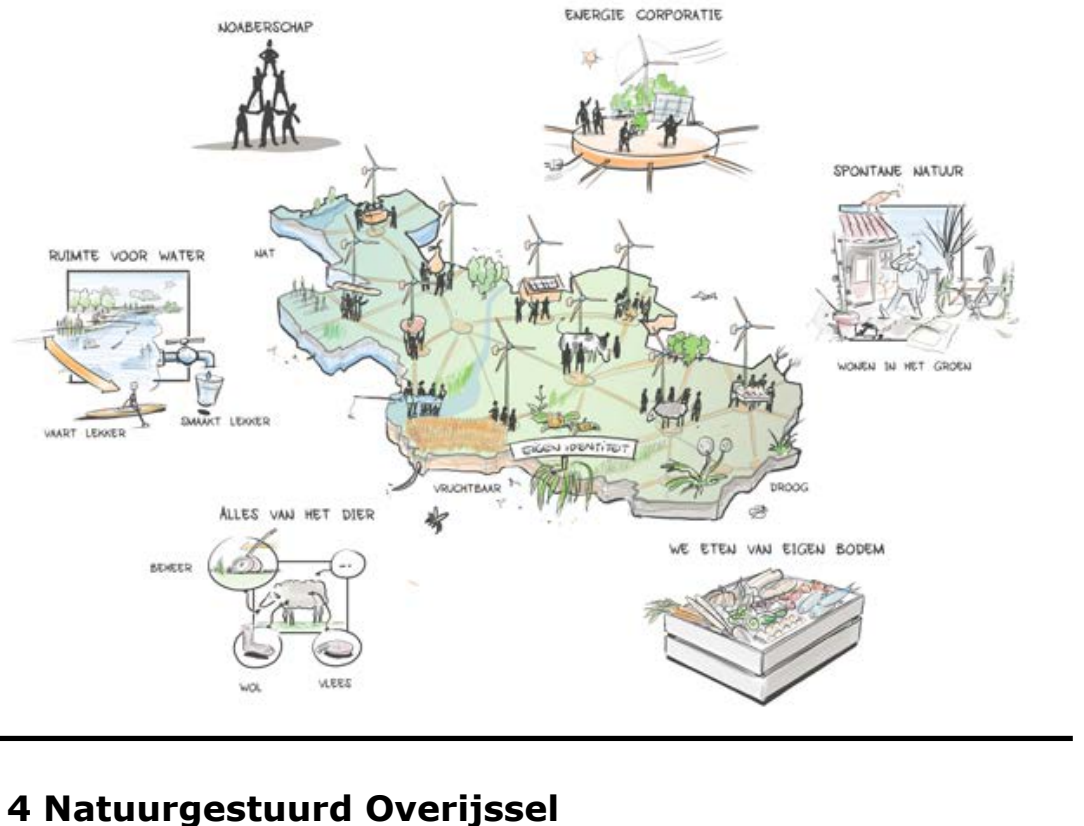

4 Natuurgestuurd Overijssel

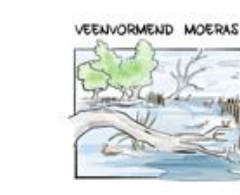

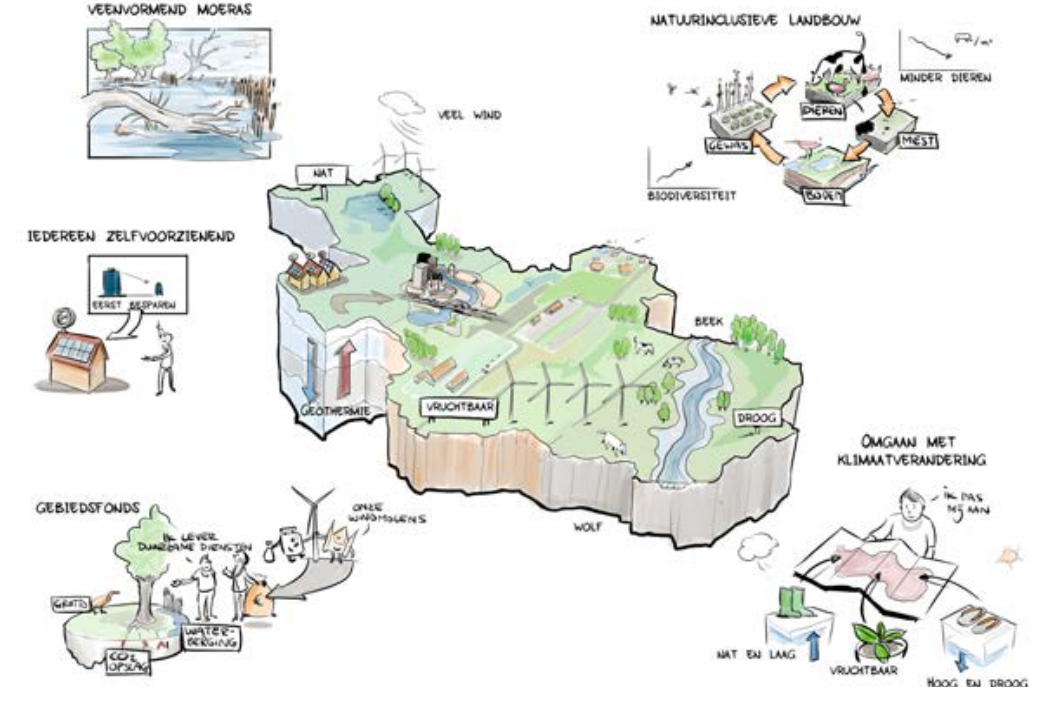

Inhoud

Introductie

Vier toekomstperspectieven

\begin{tabular}{|c|}
\hline $\begin{array}{c}\text { Marktgedreven } \\
\text { Overijssel }\end{array}$ \\
\hline $2 \begin{array}{l}\text { Samenwerkend } \\
\text { Overijssel }\end{array}$ \\
\hline 3 Geregeld Overijssel \\
\hline $4 \quad \begin{array}{l}\text { Natuurgestuurd } \\
\text { Overijssel }\end{array}$ \\
\hline Handelingsopties \\
\hline Handreiking \\
\hline $\begin{array}{l}\text { Vergelijking } \\
\text { toekomstperspectieven }\end{array}$ \\
\hline Colofon \\
\hline
\end{tabular}

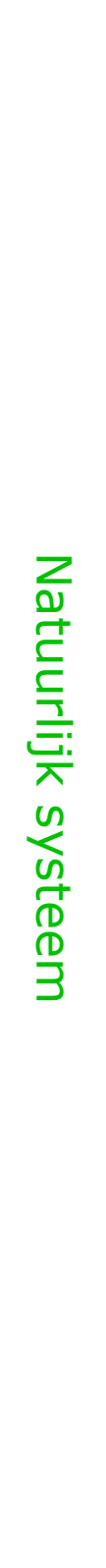

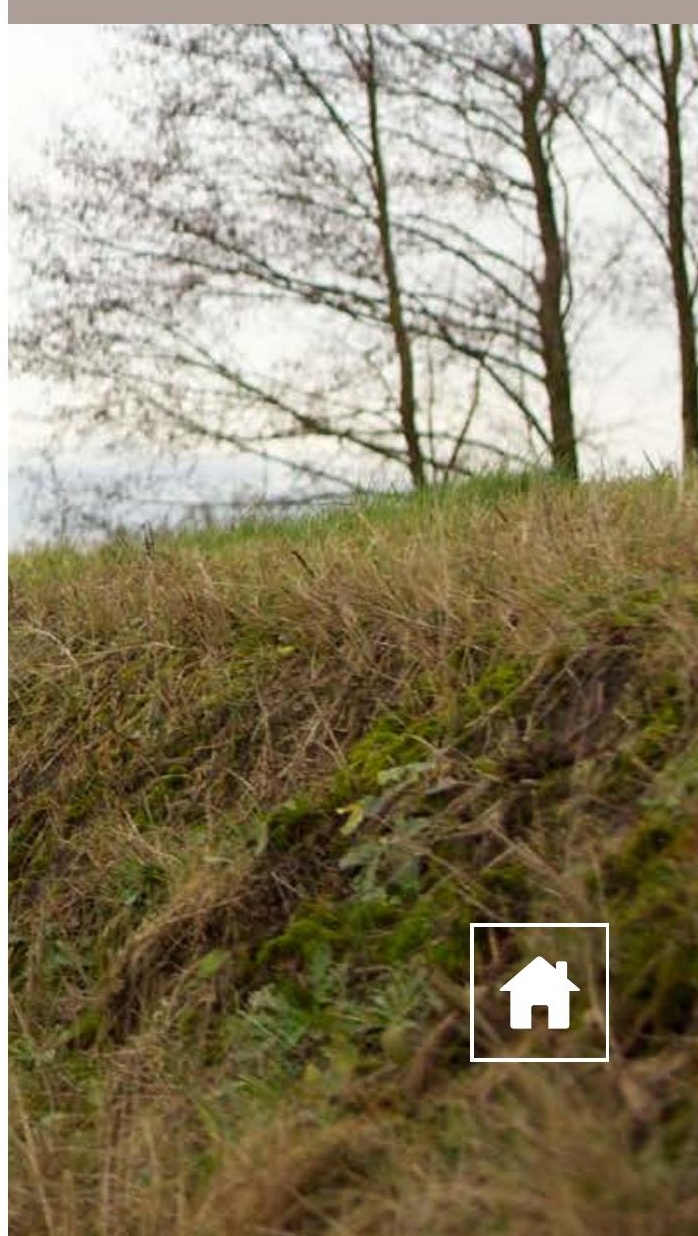




\section{Marktgedreven Overijssel}

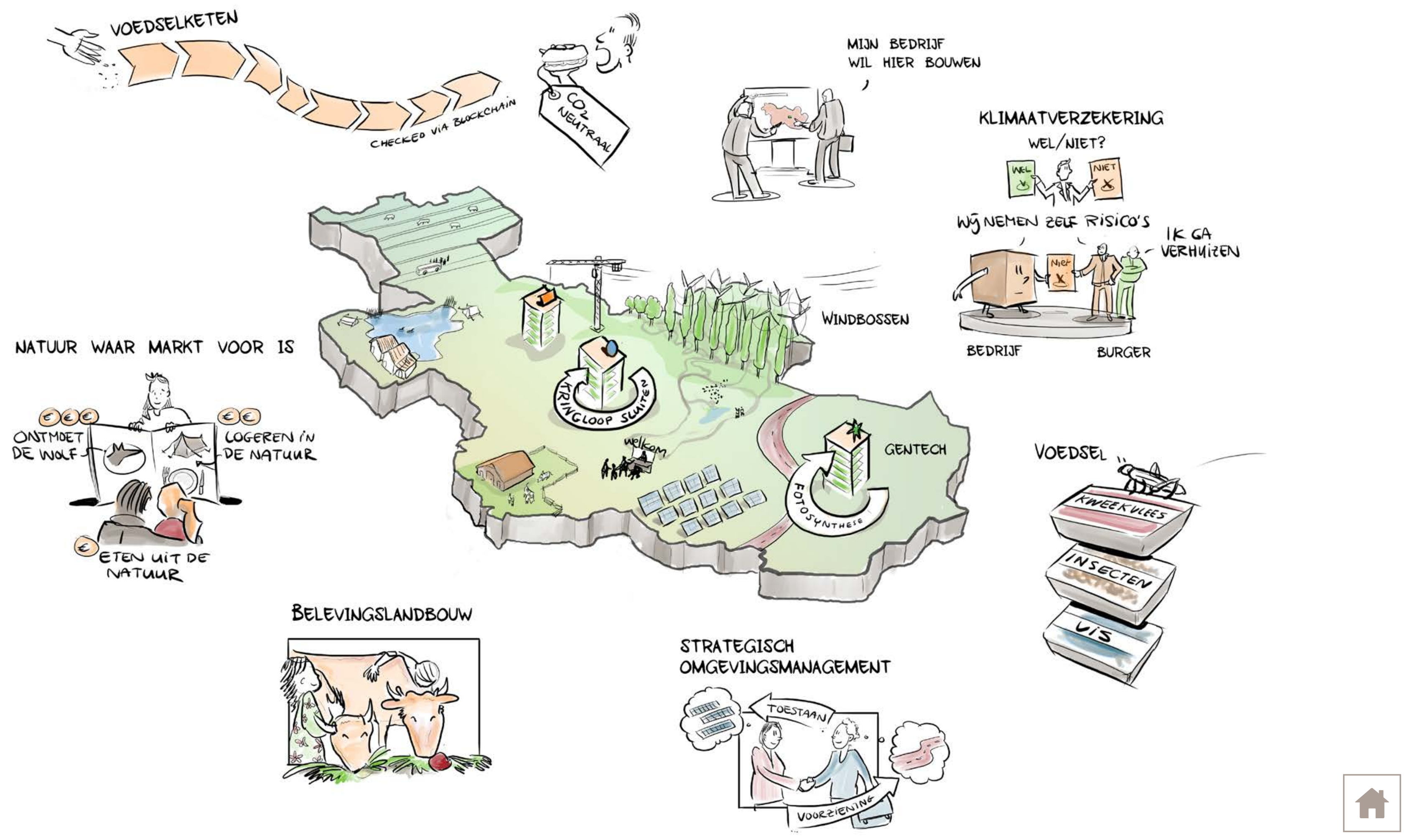




\section{Zelforganiserende samenleving, technologisch systeem als uitgangspunt}

In Marktgedreven Overijssel staat de kracht van de markt centraal. In deze marktsamenleving organiseren bedrijven en maatschappelijke organisaties zichzelf om duurzaamheidsdoelen te bereiken. Zo pakken zij (semi-)publieke taken op, zoals zorgen voor energie, voedsel, droge voeten, schoon drinkwater en biodiversiteit. Door de nieuwste technieken kostenefficiënt in te zetten, zet het bedrijfsleven natuurlijke omstandigheden naar zijn hand. Het houdt daarbij rekening met de wensen

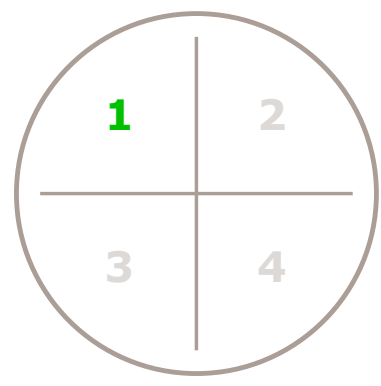
van de consument én het draagvlak bij bewoners. De overheid stimuleert, faciliteert en treedt op als wet- en regelgever.

\section{Landbouw en voedsel in Marktgedreven Overijssel}

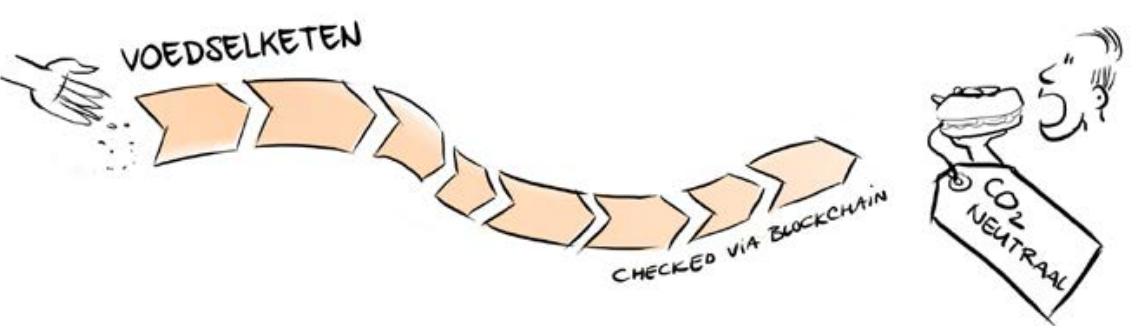

\section{Voedselinnovaties}

Het landbouw- en voedselsysteem van 2019 heeft zich in 2050 ontwikkeld naar een klimaatneutrale voedselketen. Op iedere verpakking staat: "Dit product is klimaatneutraal geproduceerd". Net als in het buitenland zijn niet-klimaatneutraal gemaakte producten ook in Overijssel niet meer toegestaan. De overheid heeft hier met regelgeving voor gezorgd, creëert zo een gelijk speelveld en zet een daarmee een stip op de horizon voor alle bedrijven. Dit geeft bedrijven voldoende tijd om daar op eigen wijze invulling aan te geven. Iedere partij in de keten, van producent, verwerker en distributeur tot retailer, is zelf verantwoordelijk voor klimaatneutraal handelen. Blockchaintechnologie zorgt voor transparante en betrouwbare voedselproductie. Overheid én consumenten kunnen zelf controleren of een product duurzaam is. Om broeikasgassen te vermijden of compenseren worden grondstoffen en energie in de keten efficiënt gebruikt of hergebruikt. Afval bestaat niet meer, er is geen voedselverspilling, verpakking en distributie zijn klimaatneutraal en er ontstaan geen verliezen in de keten.

De landbouw- en voedselketens opereren in een open internationale markt. Grote multinationals voeren een sterke regie in de gehele keten en bieden de consument diverse diensten aan. Denk aan Amazon dat FrieslandCampina heeft overgenomen. Ze introduceren nieuwe technologieën, zorgen voor kennisoverdracht en creëren werkgelegenheid. Ze werken daarvoor samen met kennisintensieve technologiebedrijven en -instituten, zoals de in Overijssel sterk aanwezige sector High Tech Systems \& Materials. Er wordt op prijs geconcurreerd en innovatie, gestimuleerd door de overheid, helpt ondernemers daarbij. Bedrijven zetten gentechnologie in om fotosynthese efficiënter te maken. Dit zorgt voor hogere opbrengsten, terwijl planten meer $\mathrm{CO}_{2}$ uit de lucht vast laten leggen in gewas en bodem. Minder grondgebonden teelt, zoals substraatteelt en hydrocultuur, maakt het mogelijk productieomstandigheden nog beter te
Inhoud

Introductie

Vier toekomstperspectieven

1 Marktgedreven Overijssel

2 Samenwerkend Overijssel

3 Geregeld Overijssel

4 Natuurgestuurd Overijssel

Handelingsopties

Handreiking

Vergelijking toekomstperspectieven

Colofon

sis $+\infty$
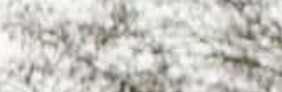

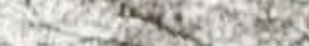
$+x^{2}$
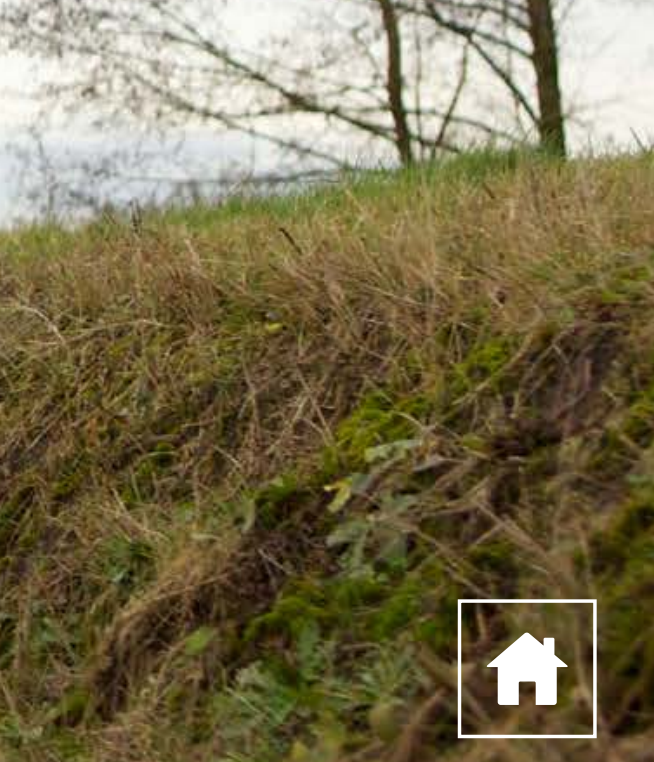
beheersen. Telers gebruiken niet alleen landbouwgrond meer, maar steeds vaker ook gebouwen in stedelijke omgeving, zoals kassen en fabriekshallen voor verticale landbouw. Dierlijke eiwitten hebben langzaam plaatsgemaakt voor plantaardige eiwitten, kweekvis, vis, algen of insecten. Deze veranderingen zorgen ervoor dat de agrarische productie in 2050 twee tot vijf keer zo productief is als in 2019 . Voedsel blijft daarmee goedkoop en bereikbaar voor iedereen. De export neemt toe. En een deel van de agrarische grond in Overijssel is niet meer nodig voor voedselproductie.

De multinationals zetten sterk in op het verkrijgen van een licence to produce van de inwoners van Overijssel. Die krijgen ze door het leveren van werkgelegenheid, met nadruk op het stedelijk gebied. Door investering van bijvoorbeeld (culturele) voorzieningen in het landelijk gebied leggen ze een duurzame verbinding tussen het bedrijf en de omgeving.

\section{Plattelandbeleving}

Naast hightech voedselproducten die in bulk gemaakt worden, blijft

\section{Energie en klimaat in Marktgedreven Overijssel}

\section{Efficiënte en goedkope energieopwekking}

Om in 2050 klimaatneutraal te kunnen ondernemen, zetten bedrijven in op efficiënte en goedkope energieopwekking en $\mathrm{CO}_{2}$-afvang en -opslag in de ondergrond. Ook hierbij speelt de overheid weliswaar een stimulerende rol, maar subsidieert zij niet. Multinationals investeren in duurzame energie, grootschalige ondergrondse $\mathrm{CO}_{2}$-opslag en bosbouw om zo onvermijdbare broeikasgasemissies in de keten te compenseren. Kostenefficiëntie is daarbij doorslaggevend. Er ontstaan slimme combinaties, zoals windmolens met productie van biomassa in windbossen.

Deze energieproductie dekt niet alleen de vraag van het landelijk gebied van Overijssel, maar levert ook voldoende voor het stedelijk gebied. Bij voldoende vraag vanuit de markt investeren bedrijven in energieparken die buiten Overijssel leveren.

Bedrijven kopen of pachten landbouwgronden in Overijssel om deze voor circa 25 jaar te gebruiken als zonnepark of windmolenpark. de consument vragen om 'ambachtelijke' producten die een authentieke beleving geven en die bijdragen aan dierenwelzijn, landschap en biodiversiteit. In hun vrije tijd trekken inwoners van Overijssel en toeristen van buiten de provincie er graag op uit om ambachtelijke bedrijven te bezoeken en 'van grond tot mond' te beleven.

Zo ontstaan nieuwe buitenplaatsen en landgoederen. Deze bedrijven verdienen aan de maatschappelijke meerwaarde die ze leveren. Denk daarbij aan land- en bosbouw, recreatie, cultuurhistorie, biodiversiteit en dierenwelzijn.

Deze bedrijven nemen maatregelen om broeikasgasemissies zoveel mogelijk te voorkomen, zoals onderwaterdrainage in de veenweiden en een aangepast dieet voor melkkoeien. Deze maatregelen moeten wel aansluiten op de authentieke beleving. Koeien houden in gesloten stallen, past daar bijvoorbeeld niet bij. Om toch klimaatneutraal te zijn, extensiveert de veehouderij in Overijssel en worden de onvermijdbare broeikasgasemissies op een kostenefficiënte manier gecompenseerd.

\section{Inhoud}

Introductie

Vier toekomstperspectieven

1 Marktgedreven Overijssel

2 Samenwerkend Overijssel

3 Geregeld Overijssel

4 Natuurgestuurd Overijssel

Handelingsopties

Handreiking

Vergelijking toekomstperspectieven

Colofon

KLIMAATVERZEKERING WEL/NIET?

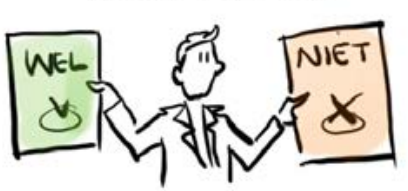

WÝ NEMEN ZELF RISICO'S

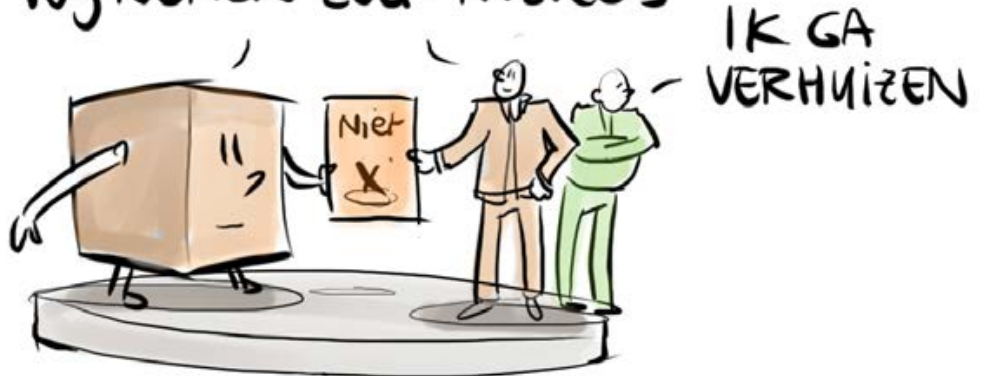

BEDRIJF
BURGER

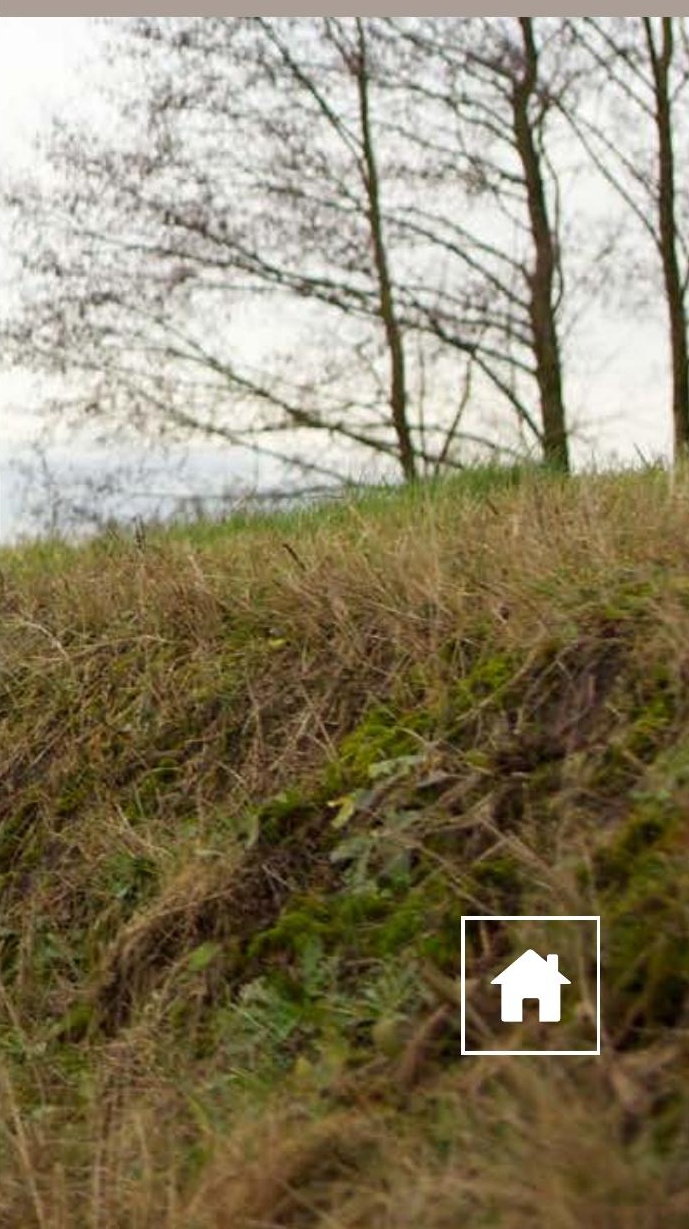


De overheid stuurt dit niet via ruimtelijke ordening: bedrijven zoeken de meest geschikte locaties en creëren zelf draagvlak voor deze energieparken bij de lokale gemeenschap. Zij zetten in op strategisch omgevingsmanagement, een aanpak die conflicten in de omgeving kan voorkomen en tegelijkertijd leidt tot een duurzame relatie met andere belanghebbenden. De komst van de energieparken leidt dan tot lagere energieprijzen voor de lokale gemeenschap of investeringen in de omgeving, zoals natuur, de aanleg van een park, infrastructuur en voorzieningen.

\section{Anticiperen op effecten van klimaatverandering}

Klimaatverandering leidt tot schade voor bedrijven en bewoners, zoals nat- of droogteschade aan gewassen en waterschade. $\mathrm{Zi}$ moeten zich daar zelf tegen verzekeren; de overheid draagt geen enkel risico. Verzekeraars zetten in op preventie en moedigen bedrijven en bewoners aan om zelf risicobeperkende maatregelen te nemen. Efficiency wordt beloond. Wie grote risico's loopt, krijgt deze niet meer vergoed of betaalt hogere verzekeringspremies. De prijs van het drinkwater stijgt mogelijk, waardoor bedrijven en bewoners zuiniger met water omgaan.

\section{Natuur en biodiversiteit in Marktgedreven Overijssel}

\section{Natuur waar een markt voor is}

Inwoners vinden natuur en biodiversiteit belangrijk en zijn bereid daarvoor te betalen. Dit leidt vooral tot de ontwikkeling van natuurtypen die mensen graag zien en beleven. Terreinbeherende organisaties ondernemen en filantropen doen aan commercieel natuurbeheer. De overheid geeft deze initiatieven volop de ruimte, op voorwaarde dat biodiversiteitsdoelen worden behaald. De natuurbeleving varieert van 'high-end-natuur' tot 'low-budget-natuur'. Er zijn privéwildparken en -landschapsparken waar aansprekende soorten voorkomen, zoals de wolf en de bever. Verder zijn er internationaal gewaardeerde landschappen (Giethoorn en omgeving), windmolenparken met natuurontwikkeling, voedselbossen en natuurgebieden met ecotoerisme.

Bedrijven met een goed verdienmodel breiden de natuurgebieden uit. De intensiteit van het gebruik verschilt: intensief rondom voorzieningen, extensief in gebieden waar bijvoorbeeld windmolens staan. Dit laat zien dat exploitatie van natuur hand in hand kan gaan met het vergroten van biodiversiteit. In agrarische gebieden

verbetert de biodiversiteit doordat grondgebonden 'belevingslandbouw' extensiever is en biodiversiteit juist 'verkoopt' als toegevoegde waarde.

\section{NATUUR WAAR MARKT VOOR IS}

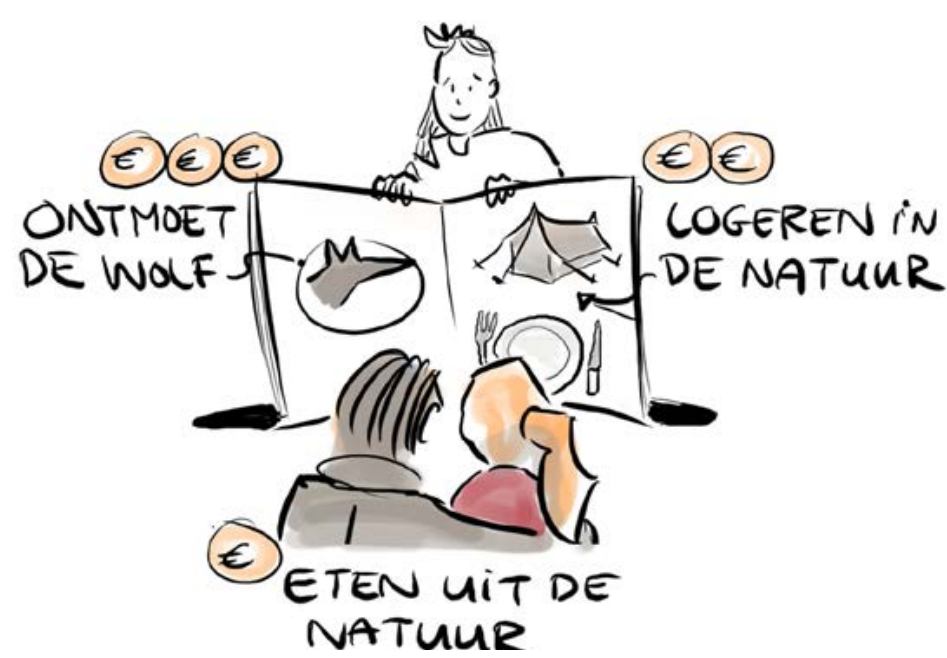

Inhoud

Introductie

Vier toekomstperspectieven

1 Marktgedreven Overijssel

2 Samenwerkend Overijssel

3 Geregeld Overijssel

4 Natuurgestuurd Overijssel

Handelingsopties

Handreiking

Vergelijking toekomstperspectieven

Colofon

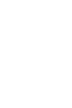




\section{Ketensturing in de markt}

Unilever wil in $2030 \mathrm{CO}_{2}$ positief produceren

Unilever heeft in haar Sustainable Living Plan de ambitie opgenomen om een bijdrage te leveren in de wereldwijde beweging om een koolstofarme economie te creëren. Ze willen het gebruik van duurzame energie verhogen om tegen $2030 \mathrm{CO}_{2}$-positief te worden in haar activiteiten. Daarnaast wil ze de broeikasgassen die gepaard gaan met het consumentengebruik van haar producten in onze waardeketen halveren.

\section{Meer over Ketensturing in de markt}

www.unilever.nl
Publieke diensten vergoeden via marktwerking Biodiversiteitsmonitor Melkveehouderij

FrieslandCampina, Rabobank en het Wereld Natuur Fonds ontwikkelen de Biodiversiteitsmonitor Melkveehouderij om te komen tot biodiversiteitsherstel in de landbouw. Uitgangspunt is om dit via verdienmodellen in de keten te ontwikkelen en daarmee minder afhankelijk te zijn van beschikbare subsidies. Een tweede uitgangspunt is dat biodiversiteitsversterkende prestaties van melkveehouders, zowel ten aanzien van biodiversiteit op het eigen bedrijf als daarbuiten, meetbaar moeten zijn.

Het is een instrument dat het eenduidig meten van biodiversiteitsresultaten mogelijk maakt en daardoor ook ingezet kan worden voor het belonen van melkveehouders via ketenpartijen en andere belanghebbenden.

Meer over Publieke diensten vergoeden via marktwerking www.biodiversiteitsmonitormelkveehouderij.nl/
Inhoud

Introductie

Vier toekomstperspectieven

1 Marktgedreven Overijssel

2 Samenwerkend Overijssel

3 Geregeld Overijssel

4 Natuurgestuurd Overijssel

Handelingsopties

Handreiking

Vergelijking toekomstperspectieven

Colofon

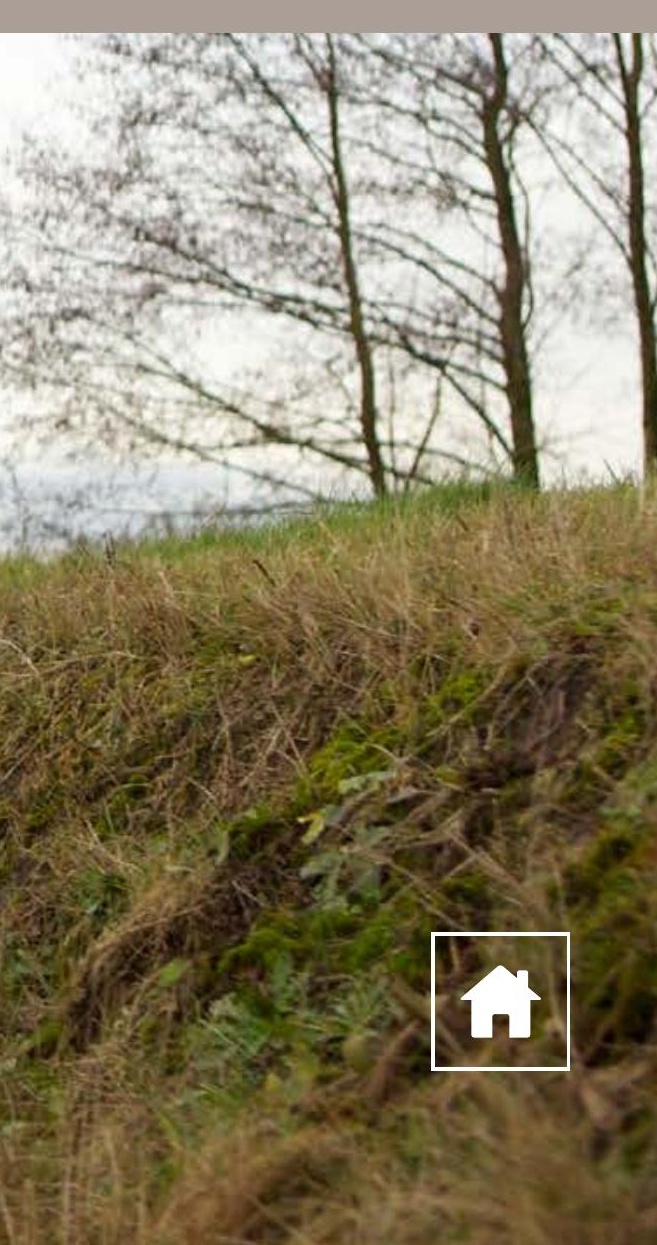




\section{Samenwerkend Overijssel}

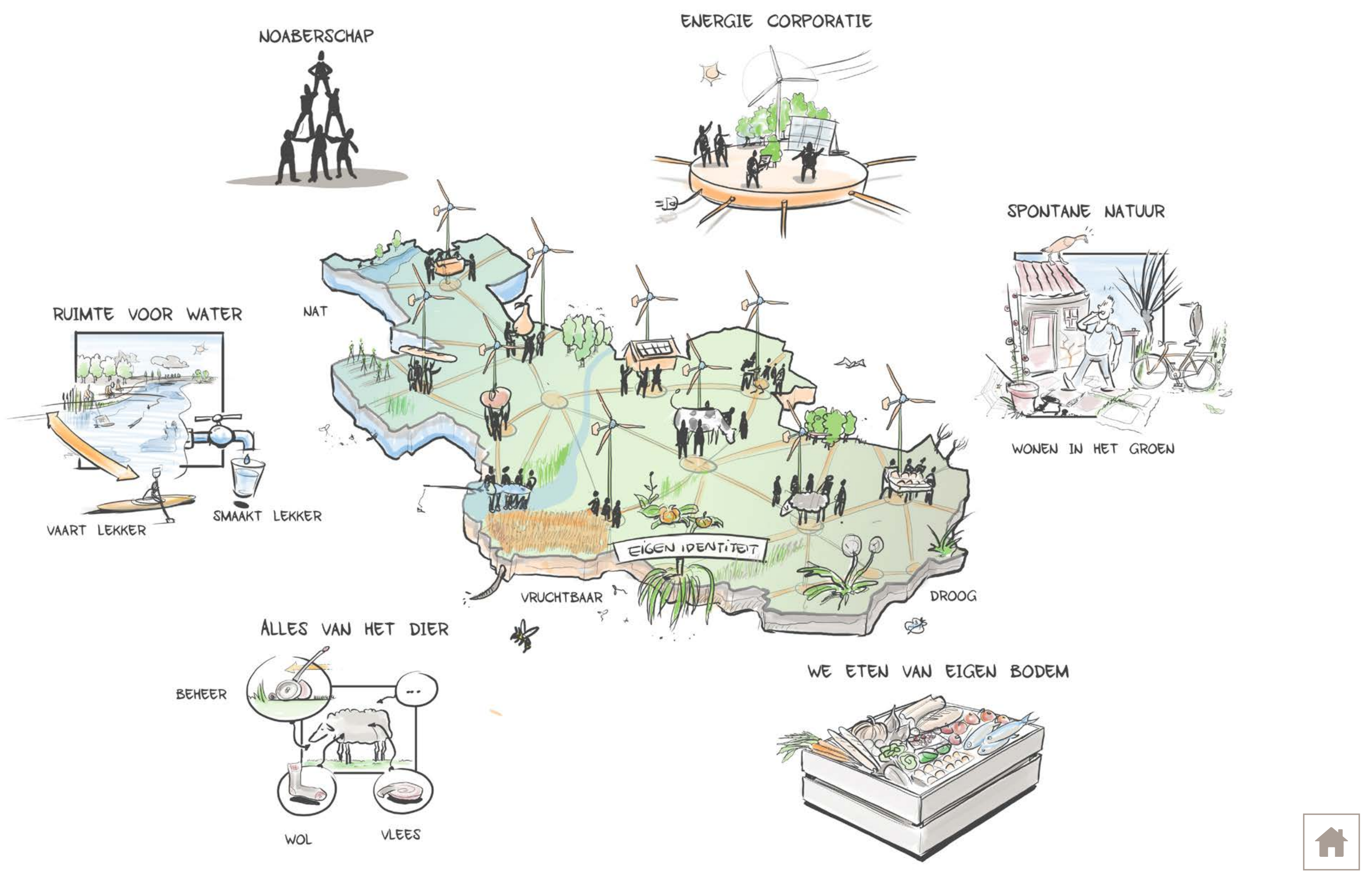




\section{Zelforganiserende samenleving, natuurlijk systeem als uitgangspunt}

In Samenwerkend Overijssel staat de kracht van de gemeenschap centraal. Lokale netwerken voorzien in basisbehoeften als voedsel en energie. De cultuur van noaberschap, 'voor en door elkaar', vormt de basis. Mensen ontlenen hieraan hun identiteit. Dit gaat gepaard met een groot respect voor natuur dat zich uit in hoe bewoners en bedrijven handelen. 'We doen het met wat de grond ons biedt', is het uitgangspunt. Er is sprake van een ambachtseconomie met duurzame ondernemingen. De overheid stimuleert het zelforganiserend en explorerend vermogen van bewoners en bedrijven.

\section{Landbouw en voedsel in Samenwerkend Overijssel}

\section{Regionale voedselsystemen}

Overijssel heeft een regionaal voedselsysteem. De lokale omstandigheden bepalen het landbouwtype. Dit maakt de voedselproductie heel divers. Er wordt voldoende voedsel geproduceerd om in de behoefte van bewoners te voorzien, uitgezonderd producten als koffie, thee, exotische vruchten en chocola. Veeteelt en natte teelten is te vinden op doorgaans nattere gronden in het rivierengebied, de veenweiden en de beekdalen. Akkerbouw en groenteteelt vindt plaats op de drogere zandgronden. In 2050 is de veestape vergeleken met 2019 fors gekrompen en dat geldt ook voor het areaal grasland. Er zijn juist meer akkerlanden waar granen en groenten worden geteeld. Per saldo heeft Overijssel in 2050 minder landbouwgrond nodig.

Grondprijzen zijn hoog, omdat er veel vraag is naar grond. Deze grote vraag ontstaat doordat naast voedselproductie ook de opgaven voor duurzame energieopwekking, biodiversiteit en klimaatmitigatie en -adaptatie vragen om ruimte. Het gevolg is dat meervoudig ruimtegebruik noodzakelijk is.

Voor het huidige dieet van de 1,1 miljoen inwoners van Overijssel is nagenoeg hetzelfde areaal nodig als nu door de landbouw in Over-

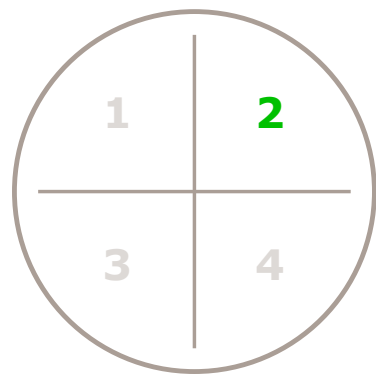

\begin{tabular}{|c|}
\hline Inhoud \\
\hline Introductie \\
\hline $\begin{array}{c}\text { Vier toekomst- } \\
\text { perspectieven }\end{array}$ \\
\hline 1 Marktgedreven \\
Overijssel \\
\hline 2 Samenwerkend \\
Overijssel
\end{tabular}

\section{WE ETEN VAN EIGEN BODEM}

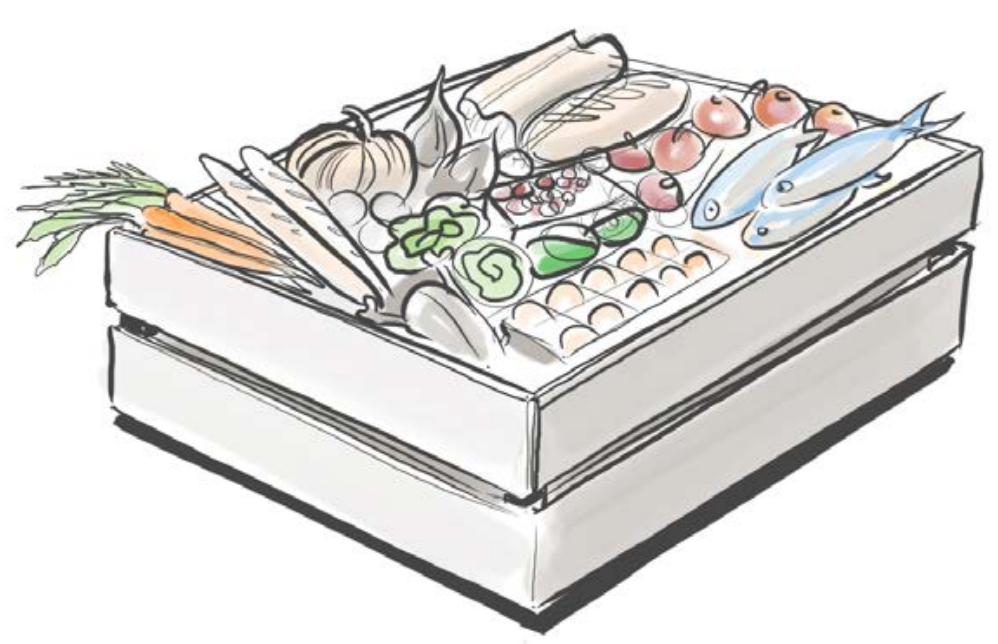

ijssel gebruikt wordt. In dit toekomstbeeld extensiveert de landbouwproductie en landbouwgrond krijgt deels een andere functie, zoals natuur of energieparken. Dit betekent dat 'eten van eigen bodem' alleen mogelijk is, doordat inwoners hun dieet aanpassen, en vooral minder vlees eten.

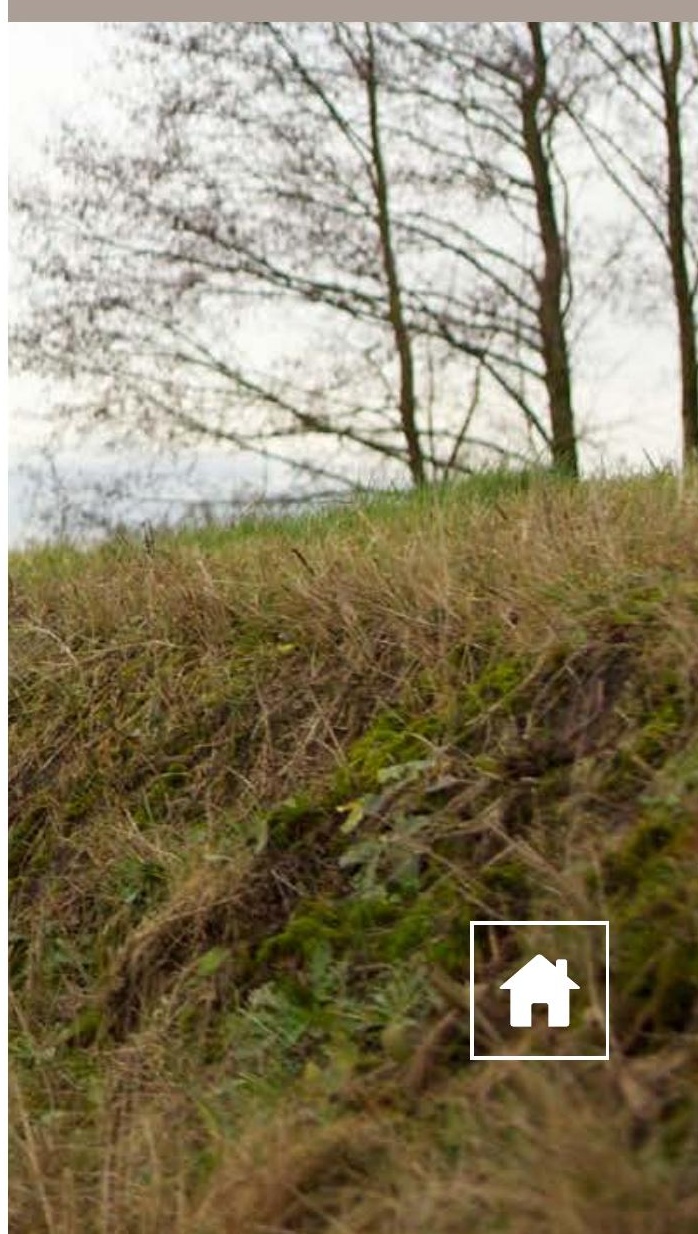


Via coöperatieve vormen als het Marke 2.0-systeem wordt de voedselproductie georganiseerd. Dit houdt in dat een collectief van boeren de gronden beheert en dat bewoners/consumenten participeren. Zij nemen niet alleen producten af, maar hebben ook inspraak in de wijze van produceren. Via deze korte keten is de gewenste productie en afzet direct geregeld. Gemeenschappen rond lokaal voedsel krijgen ook technologisch en digitaal vorm. Slimme vormen van distributie en retail brengen het voedsel bij de stedelijke consument. Techniek wordt ingezet om de herkomst van lokale producten te garanderen.

\section{Slim gebruik van grondstoffen en productiemiddelen}

De provinciale kringlopen zijn gesloten. Mest is waardevol om de bodem vruchtbaar te houden, terwijl al het veevoer uit Overijsse komt. De dierenrassen die meerdere doelen dienen, zoals vlees, wol en melk, zijn populair. Het grondwaterpeil heeft een natuurlijk beloop. De veenweide is daardoor veel natter, waardoor de uitstoo van broeikasgassen door veenoxidatie is gestopt. De lokale gemeenschap teelt hier lisdodde, cranberries en rijst en er is ruimte voor visserij. Op drogere gronden is vlas een interessant gewas voor de vezel-, verf- en textielindustrie. Bossen, aangeplant voor bouwmaterialen en voedsel voor de gemeenschap, geven een boost aan recreatie en toerisme. Emissie van broeikasgassen en stikstof worden dankzij deze activiteiten vermeden of gecompenseerd.

\section{Energie en klimaat in Samenwerkend Overijssel}

\section{Veerkrachtig systeem vraagt aangepast landgebruik}

Om goed om te gaan met weerextremen, maken bewoners en bedrijven slim gebruik van bodem, het reliëf, het watersysteem en de natuur. Zij gebruiken het stroomgebied van beken en rivieren om water te bergen bij veel regen en vast te houden voor drogere tijden. Het grondgebruik is hierop aangepast. Mensen kiezen ervoor om niet meer in stroomgebieden te wonen, omdat daar teveel risico's aan kleven. Ook het agrarisch gebruik is daar extensiever. In gebieden waar in droge tijden geen aanvoer van water mogelijk is, kan het agrarisch gebruik zelfs verdwenen zijn. Daar is meer ruimte voor bos en natuur, eventueel in combinatie met agrarisch medegebruik, zoals schapen.

\section{Gemeenschappen wekken eigen energie op}

Lokale gemeenschappen wekken lokaal energie op en besparen daarnaast zeer bewust energie. Bewoners en bedrijven hebben volledige zeggenschap over de energiebehoefte. Er zijn energiecoöperaties ontstaan die investeren in wind- en zonne-energie, omdat lokale energieopwekking met deze bronnen relatief eenvoudig is. Er is sprake van een divers en fijnmazig energie- netwerk. Daken worden volop benut, maar om de steden ook te bedienen exploiteren coöperaties ook grotere energieparken. Lokale coöperaties verdienen daarmee aan energieproductie.

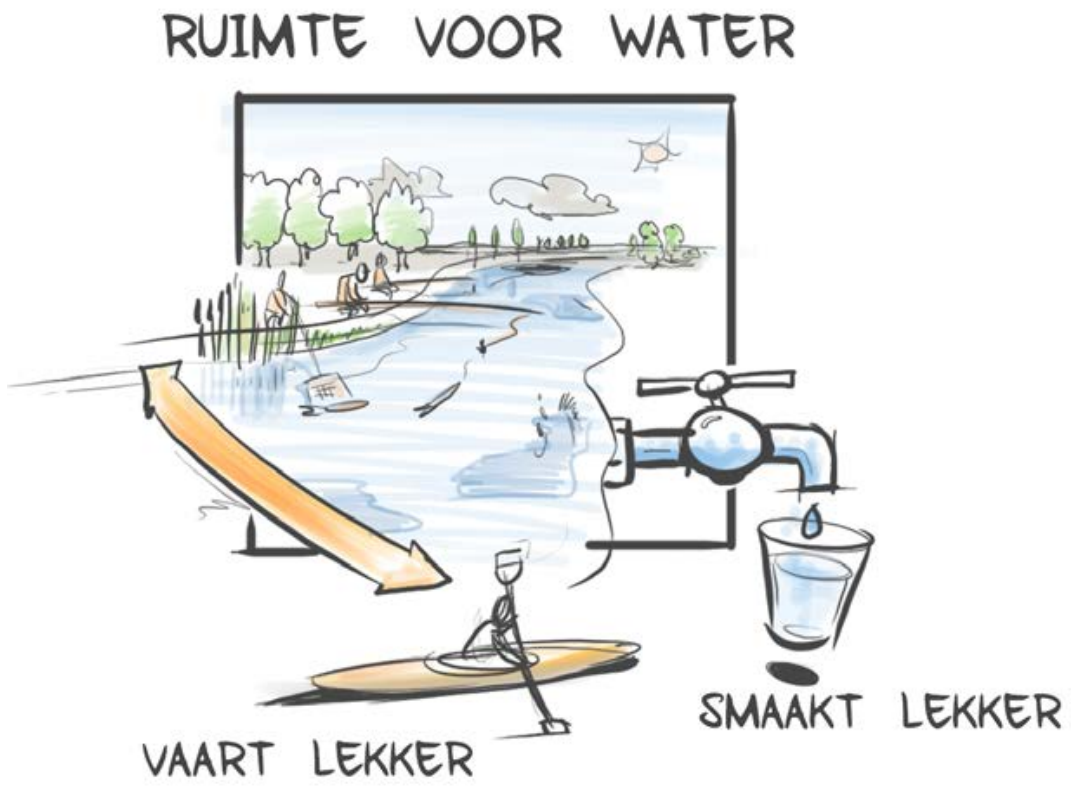

Inhoud

Introductie

Vier toekomstperspectieven

1 Marktgedreven Overijssel

2 Samenwerkend Overijssel

3 Geregeld Overijssel

4 Natuurgestuurd Overijssel

Handelingsopties

Handreiking

Vergelijking toekomstperspectieven

Colofon

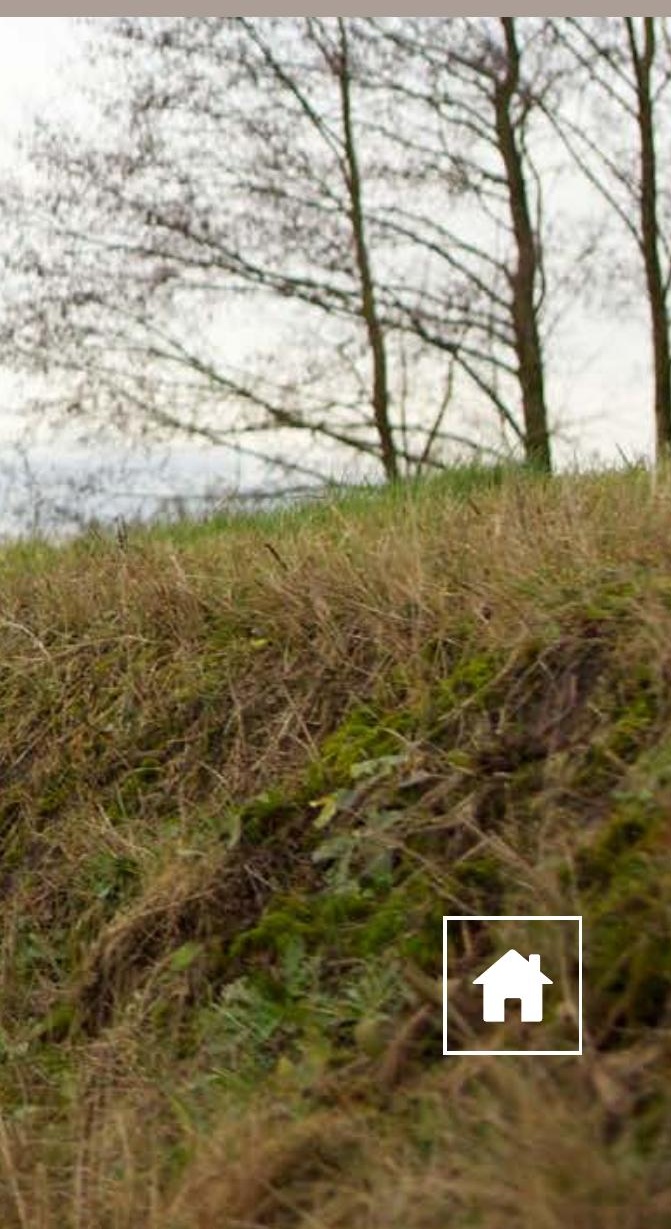




\section{Dienstverlenende natuur}

De natuurlijke laag bepaalt welke natuur zich daar 'van nature' vestigt. Er is spontane natuur ontstaan; soorten gaan en komen.

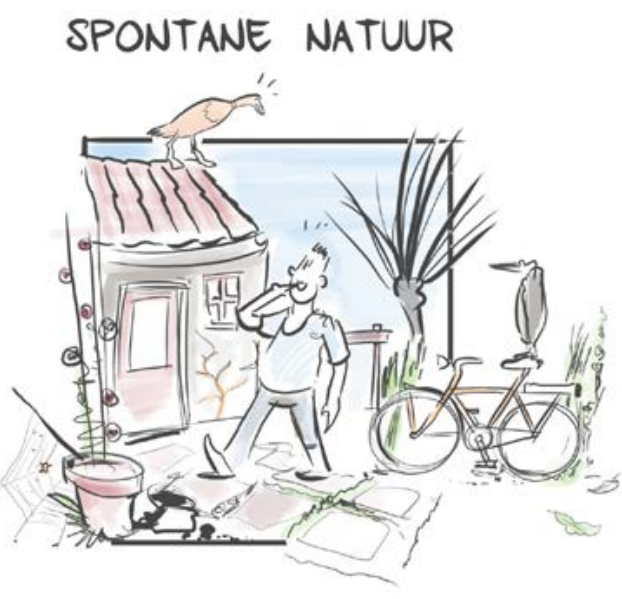

WONEN IN HET GROEN
Door diversiteit in condities en ruimte in Overijssel is de natuur bestand tegen klimaatverandering. Op sommige locaties is er mee natte natuur doordat het natuurlijk watersysteem zich herstelt, zoals in de beek- en riviersystemen. Op andere locaties is het droger doordat er geen natuurlijke aanvoer van water is of doordat waterpeilen niet meer kunstmatig hoog gehouden worden. De hoogveenrelicten die er in 2019 nog waren, kunnen bijvoorbeeld verdwenen zijn, terwijl in de beekdalen lokaal spontane veenvorming plaatsvindt. Omdat het natuurlijk systeem ruimte biedt aan spontane natuurontwikkeling, zijn de biodiversiteitsdoelen ruimschoots behaald. De lokale gemeenschappen maken gebruik van wat de natuur te bieden heeft, zoals drinkwater, hout, recreatie, voedsel, vastleggen van koolstof en bergen van water. Door het diverse en extensieve agrarisch grondgebruik, is de biodiversiteit toegenomen. Dit bevordert ook de migratie van soorten tussen natuurgebieden.

\section{Signalen uit de praktijk}

Lokale coöperatie

Gebiedscoöperatie Rivierenland

Gebiedscoöperatie Rivierenland zet zich actief in om welvaart en welzijn van alle inwoners duurzaam te vergroten voor een gezond en leefbaar Rivierenland. Ze ziet duurzaamheid als maatschappelijke noodzaak, economische kans en aanjager van innovatie. De gebiedscoöperatie is een koepel van verschillende lokale coöperaties op het gebied van energie, wonen, voeding, mobiliteit en sociale cohesie. Ze ondersteunt haar leden op de thema's energievoorziening, duurzaam transport, comfortabel en duurzaam wonen, voedsel uit onze regio, zorg voor elkaar en regionale pensioenvoorzieningen. Daarbij behartigt de coöperatie de gezamenlijke belangen en speelt een rol in het verbinden en inspireren van alle betrokkenen.

\section{Meer over Gebiedscoöperatie Rivierenland} www.gcrivierenland.nl
Eten van eigen bodem

Stadslanderij Zwolle

De Zwolse Stadslanderijen is een coöperatie van boeren in de stadsrand van Zwolle die biologisch voedsel produceert en rechtstreeks verkoopt aan de Zwollenaren. Ze werkt samen met grondbezitters, restaurants, verwerkers en consumenten in de stad Zwolle. De samenwerkende boeren creëren nieuwe natuu en recreatiepaden rondom de stad en zorgen voor landschapsherstel en een vruchtbare bodem.

\section{Meer over Eten van eigen bodem}

www.stadslanderijen.n
Introductie

Vier toekomstperspectieven

\begin{tabular}{|l}
1 Marktgedreven \\
Overijssel
\end{tabular}

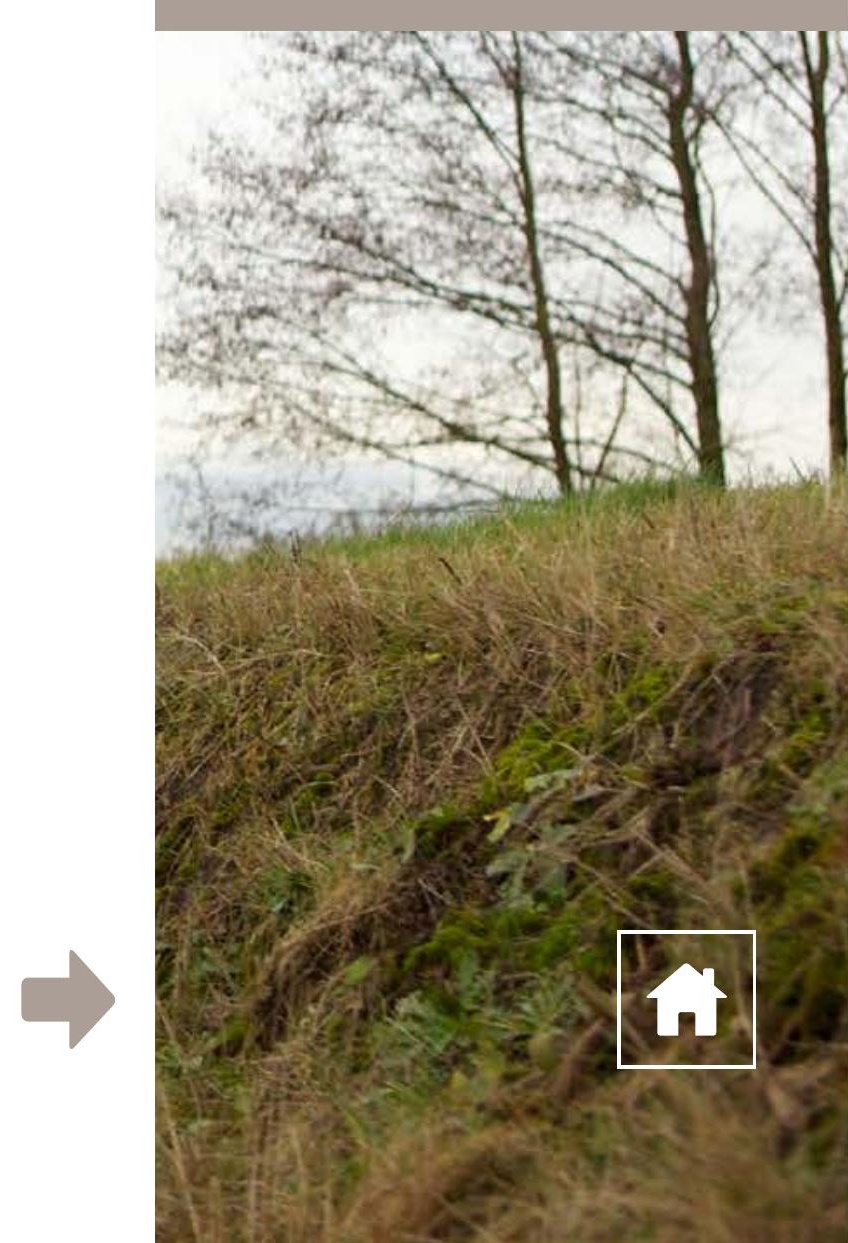




\section{Geregeld Overijssel}

VEENWEIDE ONDERWATERDRAINAGE

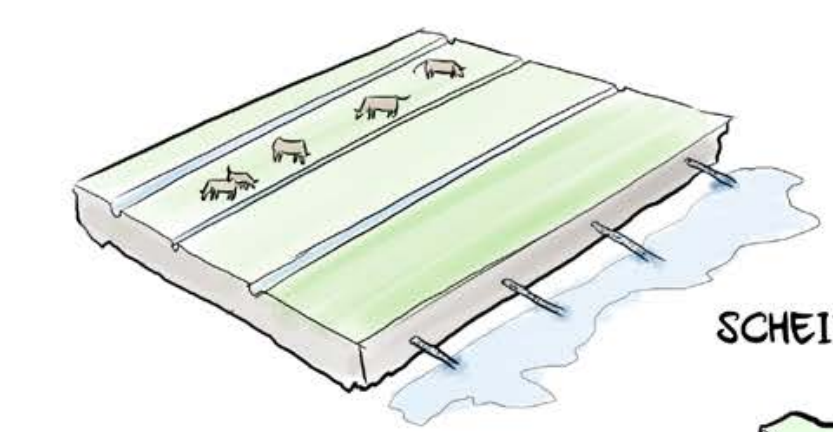

SCHEIDING LANDBOUW EN NATUUR

IJSSELMEER WATER
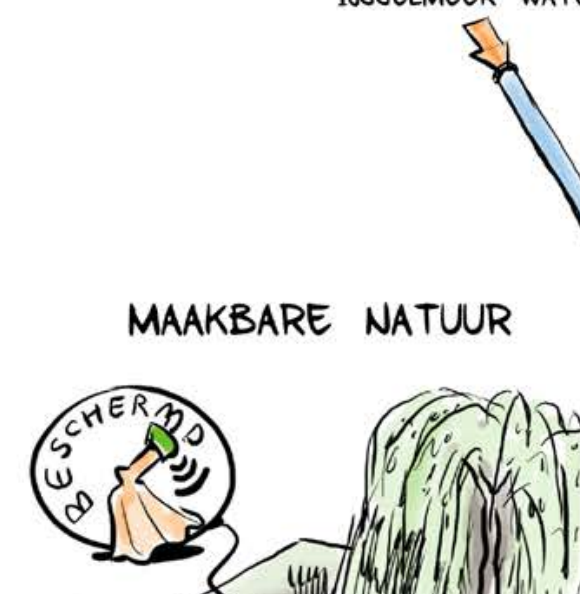

舟(

$=2$

4

BESCHERMD

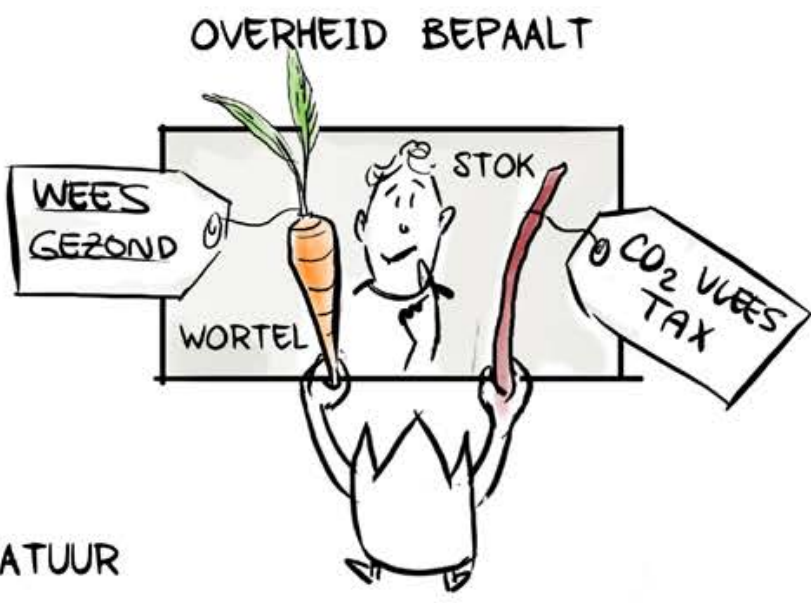

ENERGIEHOOFDSTRUCTUUR

\section{KLIMAATBOS}

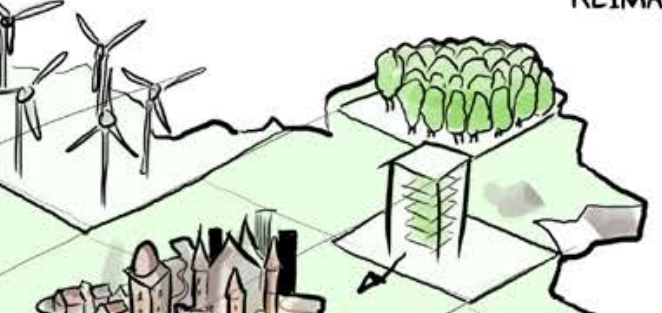

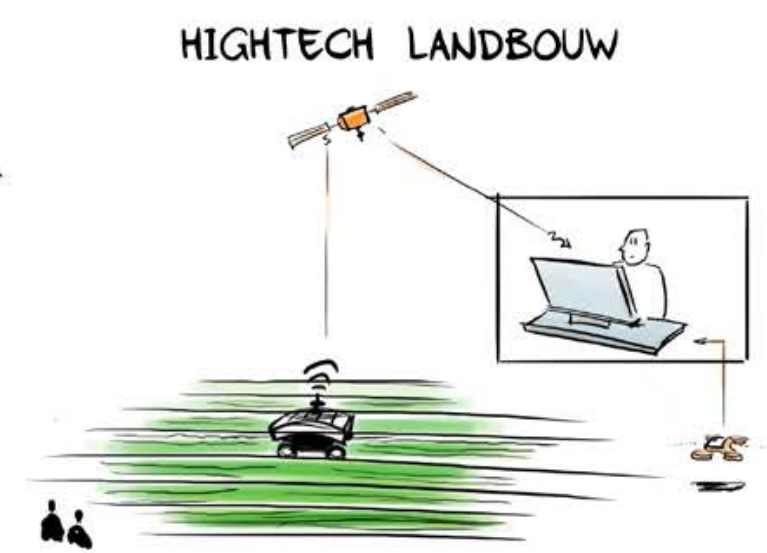

VERS GEZOND VOEDSEL

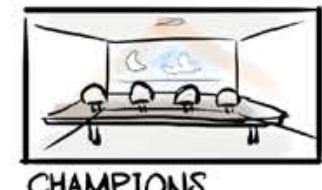

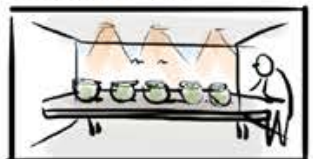

SLA

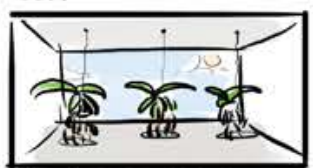

NEDERBANAAN

WATER AANVOER DROGE GEBIEDEN

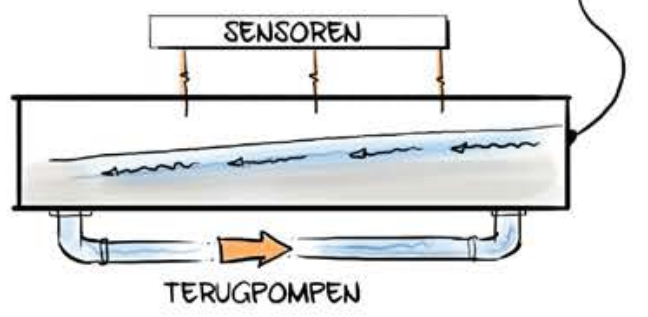

WAARDEVOL LANDSCHAP

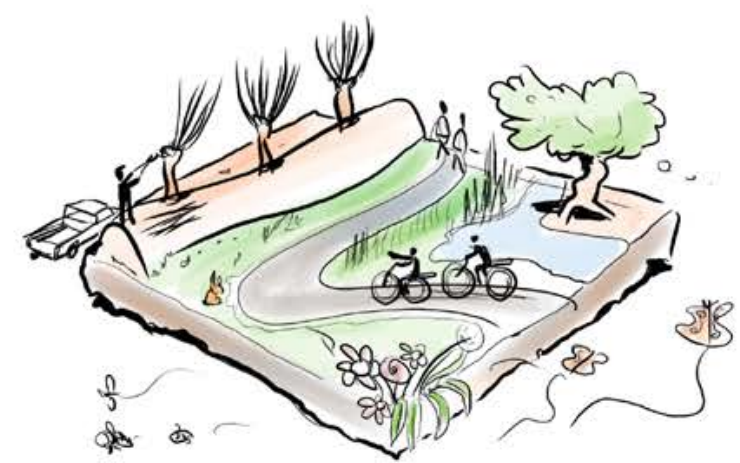




\section{Sturende overheid, technologisch systeem als uitgangspunt}

In Geregeld Overijssel ordent en stuurt de overheid actief de wijze waarop bewoners en bedrijven de duurzaamheidsopgaven moeten invullen. Dit doet zij enerzijds om de doelen veilig te stellen en anderzijds om de samenleving te 'ontzorgen'. De harde doelen van de overheid worden technologisch efficiënt behaald, met maakbaarheid als handelingsprincipe. Als het handelen van bedrijven en bewoners past binnen

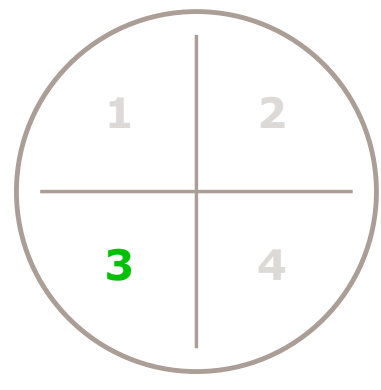
deze doelen, dan worden zij beloond. Als het niet past, wordt dit beboet.

\section{Landbouw en voedsel in Geregeld Overijssel}

\section{Voedsel als nutsvoorziening}

De overheid reguleert het hele landbouw- en voedselsysteem en

richt dat in op zoveel mogelijk productie met zo min mogelijk input

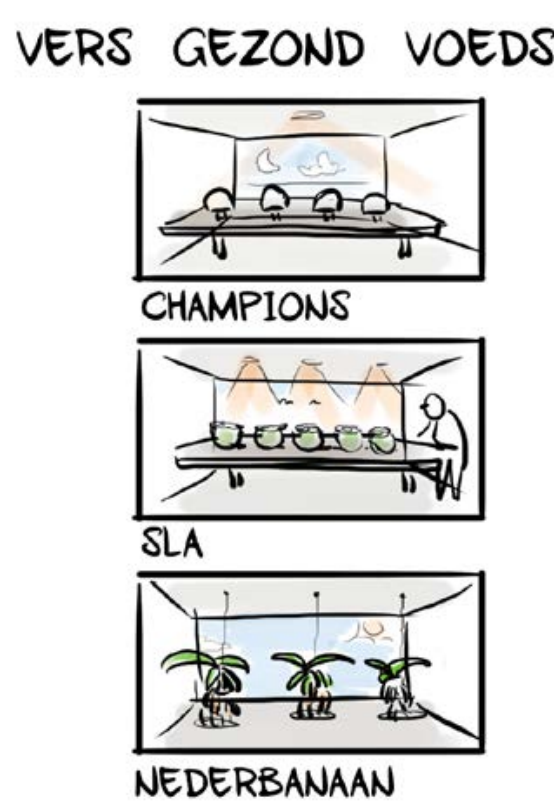

en ruimte. Gentech en hoogwaardige technologie worden ingezet om klimaatneutraal te produceren, zonder uitstoot van milieubelastende stoffen. Samen met bedrijven ontwikkelt de overheid agro- en foodparken op locaties rondom steden en knooppunten van infrastructuur. Dit zijn grootschalige parken waar kringlopen efficiënt en rendabel gesloten worden met zo min mogelijk transport.

De technologie die hiervoor nodig is, wordt in Overijssel ontwikkeld door kennisintensieve technologiebedrijven en -instituten, zoals in de sterk aanwezige High Tech Systems \& Materials sector.

De productie van versproducten is ruim genoeg voor alle inwoners van Overijssel en voor export van naar, vooral, Noordwest-Europa. De wereldmarkt voorziet in klimaatneutrale grondstoffen voor deze parken.

De gangbare grondgebonden landbouw bestaat nog in Overijssel. Deze levert allereerst voer aan agro- en foodparken en verwerkt de mest uit deze parken. Ten tweede dragen ze bij aan de instandhouding van waardevolle cultuurhistorische en recreatief aantrekkelijke landschappen. Voorbeelden zijn Noordoost-Twente en de veenweiden in Noordwest-Overijssel. Voedselproductie is complementair aan de recreatieve beleving in deze gebieden: met recreatie wordt

\section{Inhoud}

Introductie

Vier toekomstperspectieven

\begin{tabular}{|c|c|}
\hline $\begin{array}{c}\text { Marktgedreven } \\
\text { Overijssel }\end{array}$ \\
\hline 2 Samenwerkend \\
Overijssel
\end{tabular}

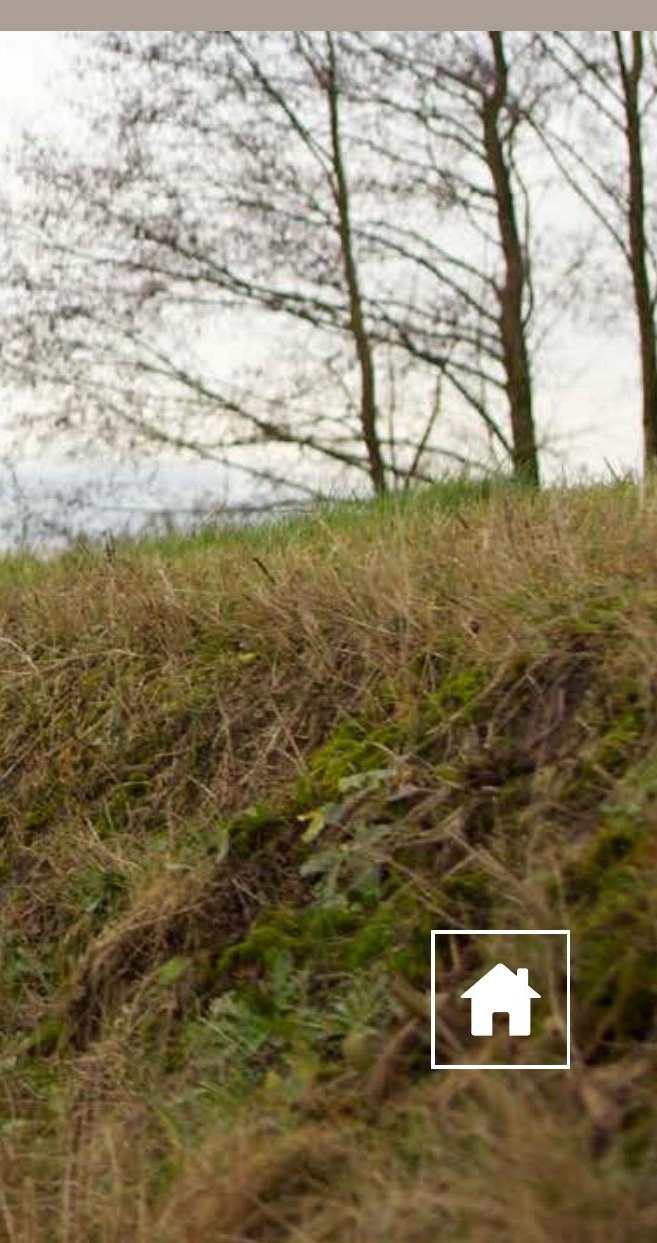


het meeste geld verdiend. Technieken als bodemsensoren, precisiebemesting en -bewerking, bestuiving via drones en (onderwater) drainage dienen om emissies naar het milieu onder gecontroleerde omstandigheden te voorkomen.

\section{Bewust omgaan met voedsel}

De overheid stuurt op het voorkomen van voedselverspilling en stimuleert een duurzaam voedselpatroon. Een nieuwe, wetenschappelijk gefundeerde Schijf van Vijf, geeft weer wat gezond én duur-

\section{Energie en klimaat in Geregeld Overijssel}

\section{Energiehoofdstructuur}

De opwekking van duurzame energie vindt geclusterd plaats in een 'energiehoofdstructuur'. De overheid stelt de energiemix vast op basis van efficiëntie en voert deze planmatig en stapsgewijs uit. Zon en wind zorgen voor grootschalige energieopwekking. Hiervoor gebruikt de overheid haar eigen gronden maximaal. Zo staan er windmolens langs infrastructuur, met zonnepanelen als geluidsschermen. Misschien zijn er al nieuwe, efficiëntere technieken beschikbaar, zoals opwekking met thorium. Dan stapt de overheid af van wind- en zonenergie. Geothermie zet zij in voor stadswarmte. Opgewekte energie die niet direct nodig is, slaat de overheid op in waterstof. Internationale samenwerking stelt de levering van energie zeker. Verder legt de overheid in bouwbesluiten en vergunningen op dat nieuwe gebouwen, bedrijfsactiviteiten en industriële activiteiten energieneutraal moeten zijn of energie moeten leveren. Via een $\mathrm{CO}_{2}$-taks voor bestaande gebouwen en activiteiten stimuleert de overheid energiebesparing.

\section{Sturen op water}

Met slim waterbeheer anticipeert de overheid op de effecten van klimaatverandering. Met grote waterwerken is het precies te bepalen wanneer het nodig is om water vast te houden of juist af te zaam is. Via regels en 'nudging' worden consumenten 'gestuurd'. Producten met veel broeikasgasemissies, zoals dierlijke eiwitten, en ongezond voedsel, krijgen een vet-, suiker-, $\mathrm{CO}_{2}$ - of vleestaks. Doordat het eetpatroon verandert, verschuift de voedselproductie naar groenten, fruit en peulvruchten, kip en vis. Rood vlees wordt minder geproduceerd. De agro- en foodparken produceren voedse on demand en just in time en mensen consumeren deze als versproducten.

\section{WATER AANVOER DROGE GEBIEDEN}

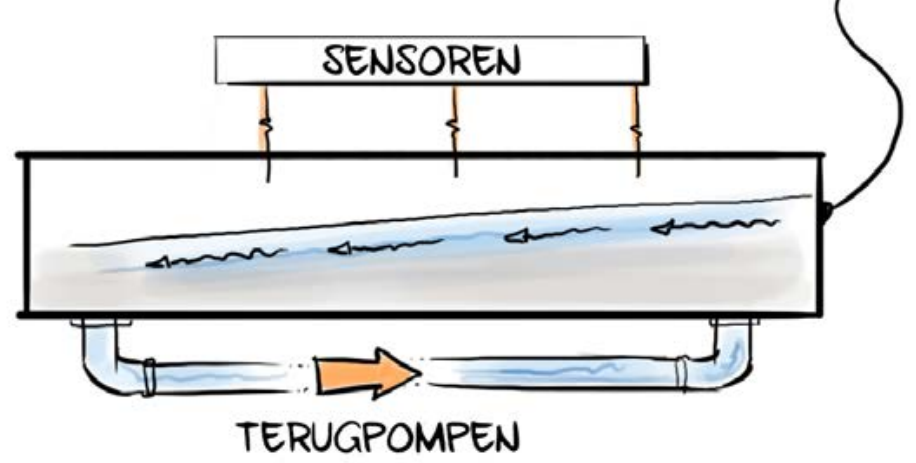

voeren. Beken en rivieren zijn ingericht om te kunnen bufferen en afvoeren. Dit voorkomt extreme wateroverlast en langdurige droogte. Onderwaterdrainage met drukdrains zorgt voor een grondwaterpeil dat veenoxidatie in veengebieden grotendeels voorkomt. Tijdens langdurige droogte krijgt de droge zandgrond in Twente ondergronds water afkomstig uit het westen van Overijssel en het IJsselmeer.
Inhoud

Introductie

Vier toekomstperspectieven

1 Marktgedreven Overijssel

2 Samenwerkend Overijssel

3 Geregeld Overijssel

4 Natuurgestuurd Overijssel

Handelingsopties

Handreiking

Vergelijking toekomstperspectieven

Colofon

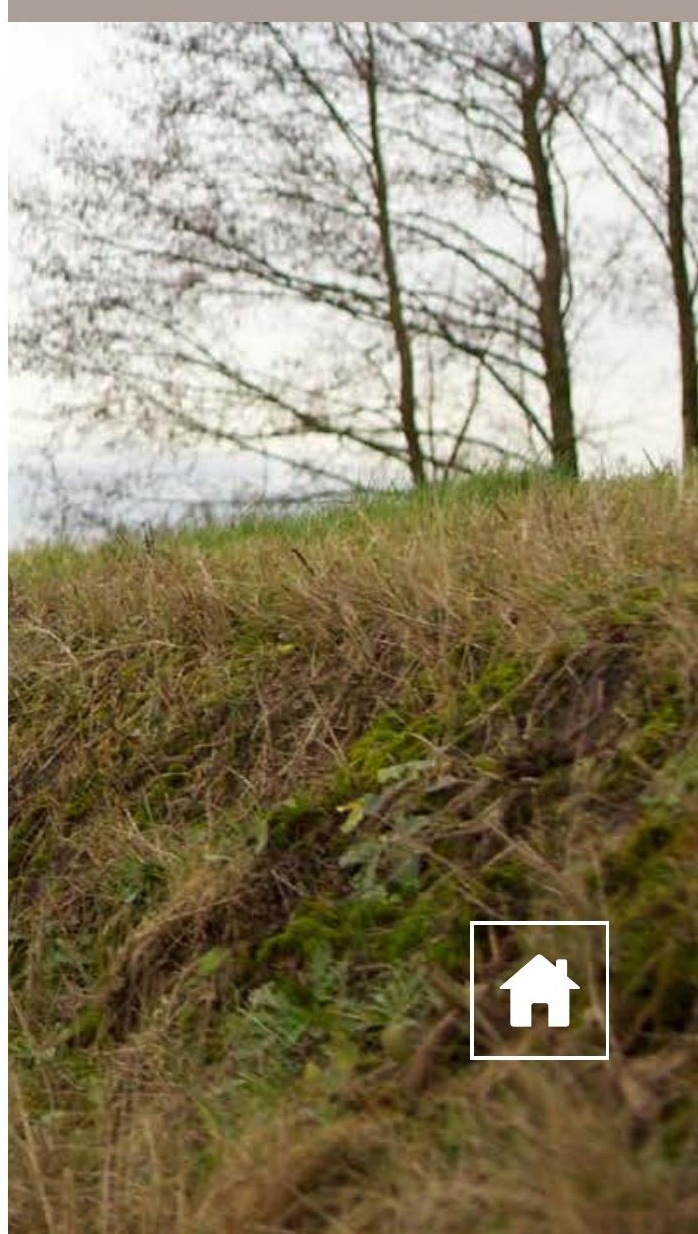




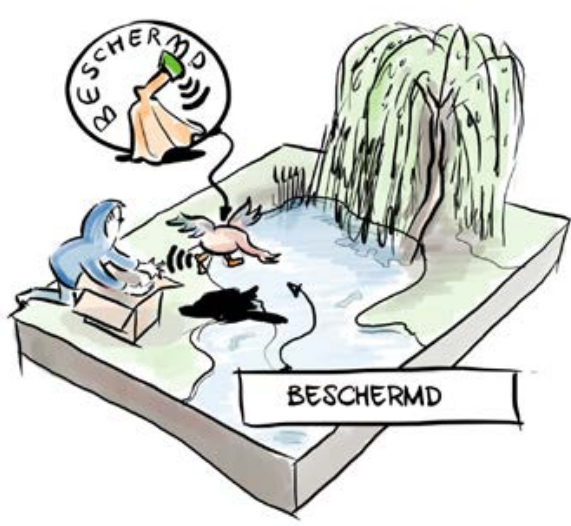

\section{Beheersbare natuur}

De overheid zet vol in op natuurbeheer, gescheiden van andere

functies. Natuurgebieden worden ingericht en beheerd met als doel, de gewenste diversiteit in soorten te behouden. Natuurbeheer wordt verder gebruikt om de onvermijdbare broeikasgassen te compense-
MAAKBARE NATUUR

ren door koolstof in bos vast te leggen. Natuurgebieden zijn waar nodig groter geworden en met elkaar verbonden om soorten voldoende ruimte te geven. Dit is nodig als technische maatregelen niet mogelijk zijn of als het goedkoper is om gebieden te verbinden. De overheid houdt de biodiversiteit goed in de gaten en kan soorten desgewenst ook opnieuw introduceren, zoals gebeurde met de korhoen op de Sallandse Heuvelrug. In zeer waardevolle natuurgebieden waar optimale omstandigheden niet op natuurlijke wijze aanwezig blijven, worden deze met technische hulpmiddelen in stand gehouden. De hoogveenrestanten zijn daar voorbeelden van.

Voor gewenste soorten die verbonden zijn aan agrarische cultuurlandschappen, zoals weidevogels, heeft de overheid reservaten aangelegd. Hier wordt agrarisch natuurbeheer toegepast.

De overheid bevordert de gezondheid door natuurbeleving te stimuleren en richt de natuurgebieden daarop in.

\section{Signalen uit de praktijk}

Wetenschappelijk verantwoorde schijf van vijf

EAT-Lancet-menu: de Schijf van 2050?

In januari 2019 werd in The Lancet een alomvattende analyse van het wereldvoedselsysteem gepubliceerd met aanbevelingen voor hoe tien miljard wereldbewoners in 2050 op een gezonde en duurzame manier gevoed kunnen worden. De wetenschappers die hieraan meewerkten hebben voor het eerst in beeld gebracht wat de ecologische grenzen voor de wereldwijde voedselproductie zijn. Om binnen deze grenzen te produceren zijn grote veranderingen nodig. Er moet meer voedsel per hectare geproduceerd worden, de voedselverspilling moet gehalveerd worden en we moeten minder dierlijk, meer plantaardig gaan eten.

\section{Meer over Wetenschappelijk verantwoorde schijf van vijf} www.voedingscentrum.nl
Ondernemende Overheid

Deltawerken

Een voorbeeld van een sterk sturende overheid die ingrijpt met ramp van 1953 was er momentum voor de overheid om top-down in te grijpen in het natuurlijk systeem, om Nederland te beschermen tegen de zee. technische maatregelen zijn de Deltawerken. Na de watersnood-
Introductie

Vier toekomst-

perspectieven

\begin{tabular}{|c|c|}
\hline $\begin{array}{c}1 \\
\text { Marktgedreven } \\
\text { Overijssel }\end{array}$ \\
\hline 2 Samenwerkend \\
Overijssel
\end{tabular}

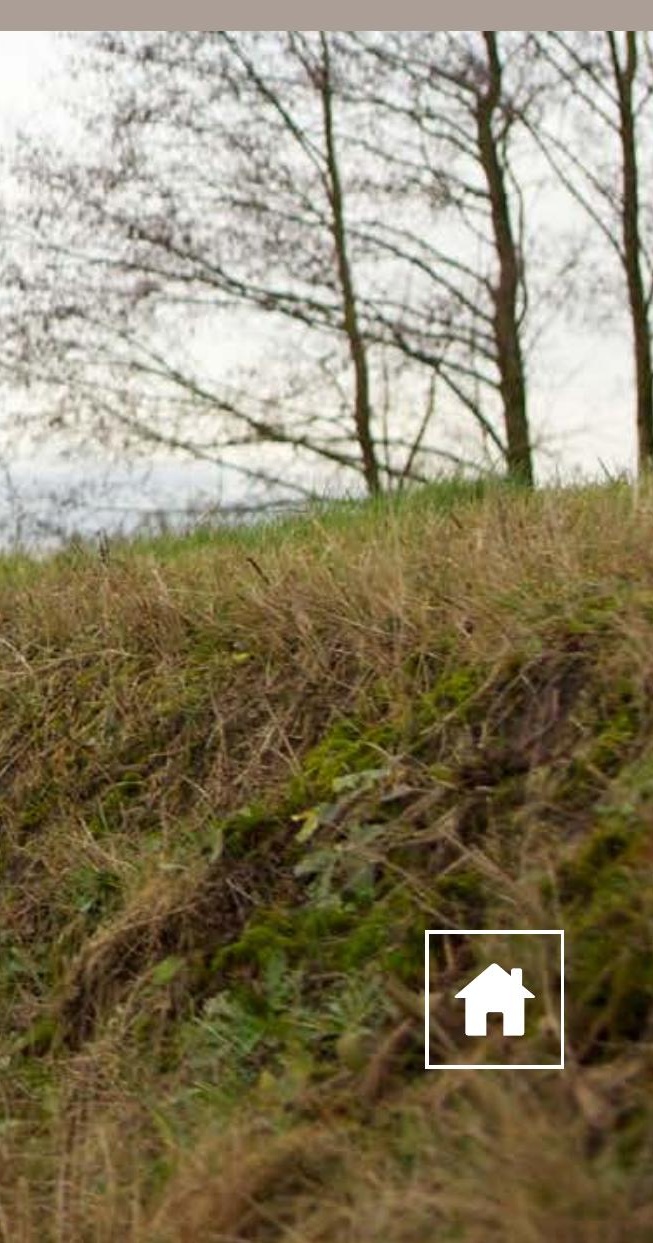




\section{Natuurgestuurd Overijssel}

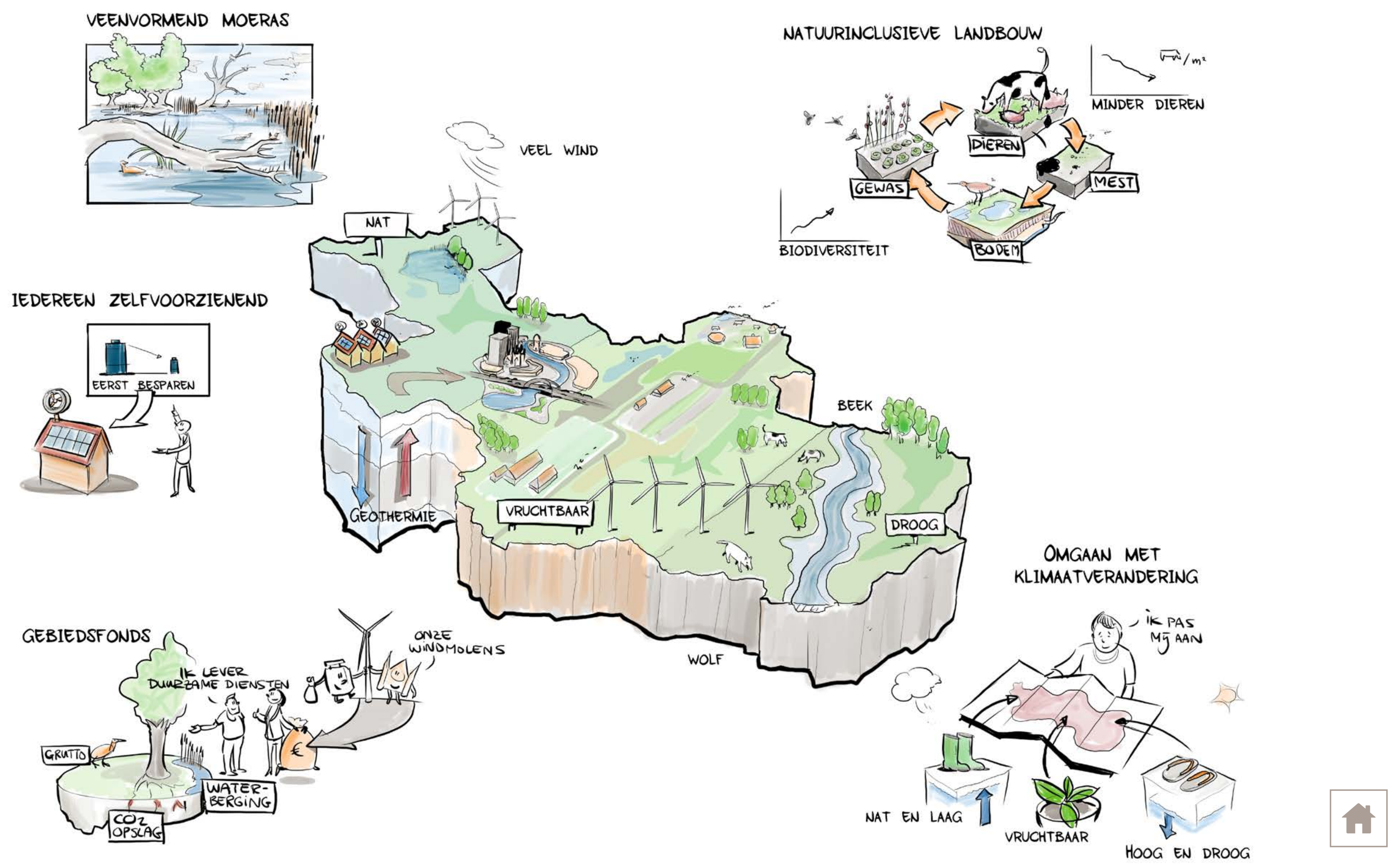




\section{Sturende overheid, natuurlijk systeem als uitgangspunt}

In Natuurgestuurd Overijssel woont, werkt en recreëert iedereen in harmonie met het natuurlijk systeem. Dat betekent dat mensen en bedrijven enerzijds gebruikmaken van bodem, water, reliëf en natuur. Anderzijds stelt dit natuurlijk systeem grenzen aan voedselproductie, de mogelijkheden voor duurzame energie en de kansen voor natuur. De overheid stuurt sterk op de veerkracht van het natuurlijk systeem.

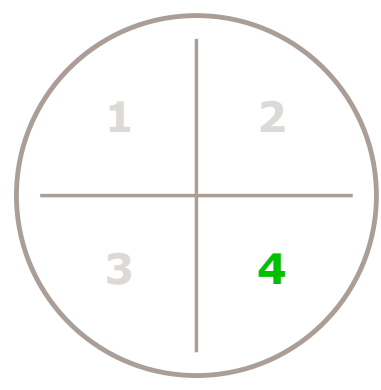
Zo stelt zij per gebiedstype de verduurzamingsopgaven vast, rekening houdend met de natuurlijke kenmerken. Ook stelt de overheid grenzen aan het gebruik van het natuurlijk systeem. Bewoners en bedrijven passen zich hierop aan of bewegen mee. Leveren zij diensten die bijdragen aan verduurzamingsopgaven, dan kunnen zij rekenen op een beloning van de overheid.

\section{Landbouw en voedsel in Natuurgestuurd Overijssel}

\section{Natuurinclusieve landbouw}

De overheid wil een veerkrachtig voedsel- én ecosysteem met zorg voor landschap, milieu en natuur en een gezonde, rendabele landbouw. Op basis van de grenzen die het natuurlijk systeem stelt, stelt zij per gebiedstype de kaders voor voedselproductie vast. Dit zijn harde kaders voor schoon en voldoende water, gezonde bodem, klimaatneutraliteit en landschappelijke en natuurlijke diversiteit. Agrarische bedrijven moeten de kringloop regionaal sluiten.

Deze bedrijven gaan uit van agro-ecologische principes. Ze bevorderen en verduurzamen de voedselproductie door gebruik te maken van natuurlijke omstandigheden en ecologische processen, zoals het zorgen voor biodiversiteit en organische stof in bodems en natuurlijke plaagregulatie. Hoewel de productie lager ligt dan in de gangbare landbouw van 2019, is de productie op lange termijn gewaarborgd. Dit is te danken aan het veerkrachtige productiesysteem dat goed kan omgaan met klimaatverandering. Agrarische bedrijven zorgen voor een vitale bodem, werken met groenbemesters, gevarieerde gewasrotaties en kruidenrijke graslanden en akkers. Ze zetten

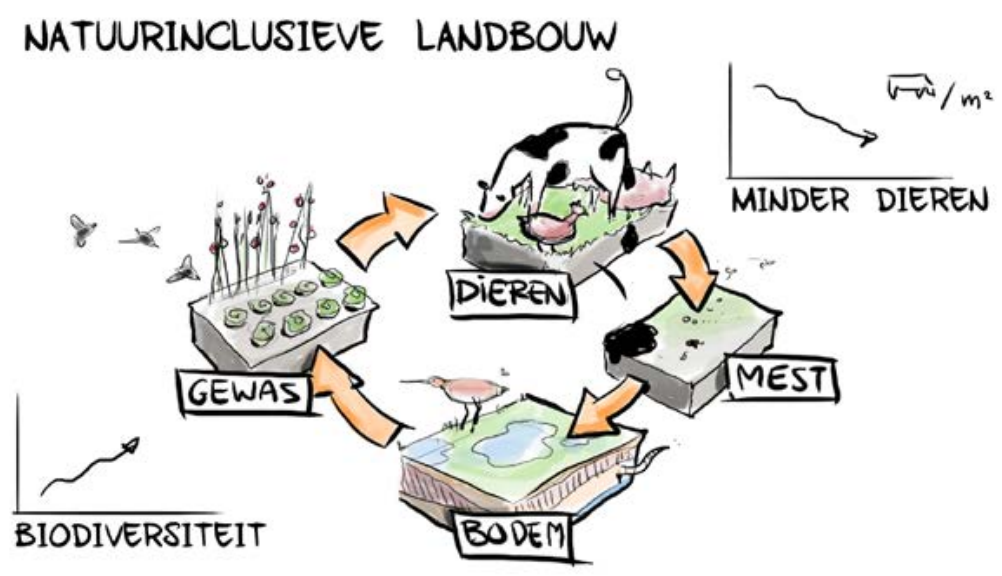

gewassen in die passen bij de lokale natuurlijke omstandigheden. Technologie gebruiken zij om de veerkracht van het natuurlijk systeem te versterken, zoals robots die grond bewerken om bodemverdichting te voorkomen of mechanisch onkruid bestrijden. Technologie om het natuurlijke systeem te manipuleren, zoals gentech, is verboden.
Inhoud

Introductie

Vier toekomstperspectieven

\begin{tabular}{|c|c|}
\hline 1 & $\begin{array}{l}\text { Marktgedreven } \\
\text { Overijssel }\end{array}$ \\
\hline 2 & $\begin{array}{l}\text { Samenwerkend } \\
\text { Overijssel }\end{array}$ \\
\hline 3 & Geregeld Overijssel \\
\hline 4 & $\begin{array}{l}\text { Natuurgestuurd } \\
\text { Overijssel }\end{array}$ \\
\hline \multicolumn{2}{|c|}{ Handelingsopties } \\
\hline \multicolumn{2}{|c|}{ Handreiking } \\
\hline \multicolumn{2}{|c|}{$\begin{array}{l}\text { Vergelijking } \\
\text { toekomstperspectieven }\end{array}$} \\
\hline Colof & \\
\hline
\end{tabular}

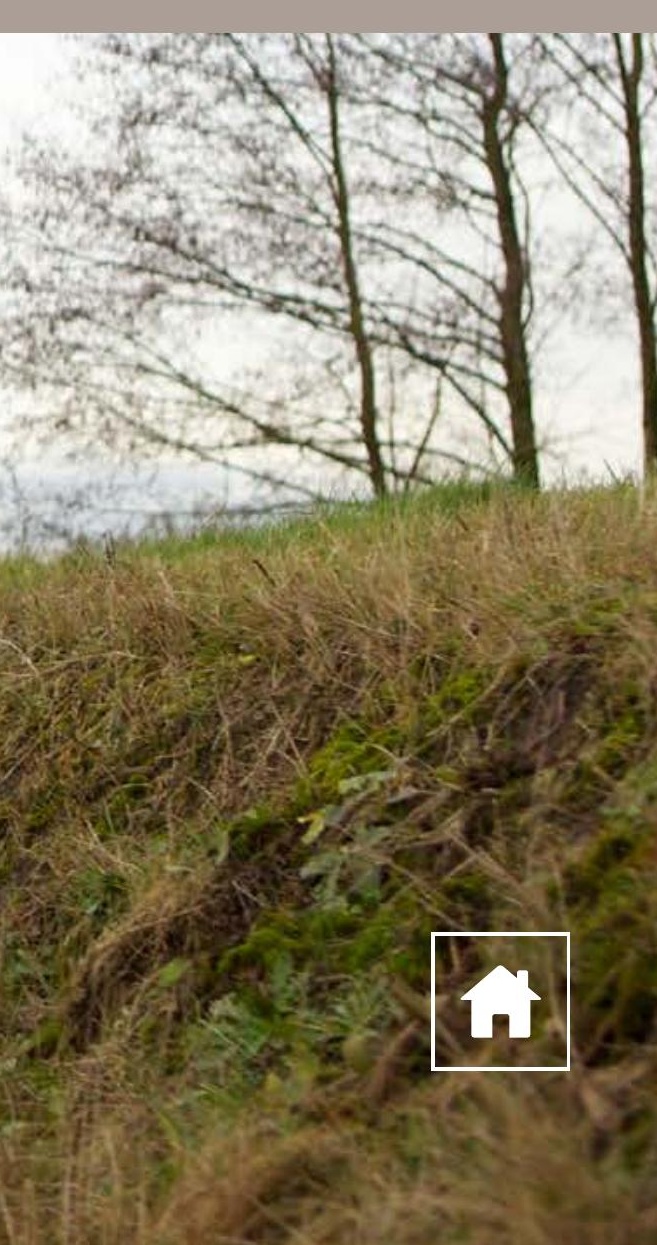


Het sluiten van de regionale kringloop betekent dat veevoer in eigen regio wordt verbouwd en dat voedselresten uit de steden tot veevoer worden verwerkt. Het benodigde fosfaat voor de landbouw wordt gewonnen uit het rioolwater van het stedelijk gebied in Overijssel. Dierlijke mest wordt bewerkt tot verschillende meststoffen die kunstmest vervangen. Vervolgens dienen agrarische bedrijven de juiste hoeveelheid mineralen op het juiste moment toe, zonder verliezen naar bodem, grondwater en lucht. Door kringloop regionaal te sluiten, krimpt de veehouderij in Overijssel.

\section{Meervoudig verdienmodel}

Agrariërs zijn overgestapt naar een meervoudig verdienmodel. Dit is nodig omdat de productie en daarmee het verdienvermogen lager ligt doordat ze produceren binnen de grenzen van het natuurlijk systeem. Ze bieden extra toegevoegde waarde door zelf of samen met andere agrarische bedrijven producten te verwerken, distribueren of verkopen. Ze zetten in op (inter)nationale branding van regionale producten. Van de overheid ontvangen ze vergoedingen voor verschillende diensten, zoals het opslaan van koolstof in bodem of bossen, landschapsbeheer en biodiversiteit. Tegen vergoeding leveren zij diensten aan hun omgeving, zoals zorg, kinderopvang of recreatie. Elk bedrijf ontwikkelt zijn eigen verdienmodel, waardoor het minder afhankelijk is van schommelingen in voedselprijzen op de wereldmarkt.

\section{Energie en klimaat in Natuurgestuurd Overijssel}

\section{Robuust watersysteem vangt klimaatverandering op}

Oude, natuurlijke watersystemen zijn zoveel mogelijk hersteld. Beekdalen zijn weer natter en houden water langer vast om droge periodes te kunnen opvangen. In de veenweiden is het peilbeheer losgelaten en ontstaat er weer een laagveenmoeras. In drinkwatergebieden zijn sloten gedempt om snelle afvoer te voorkomen en infiltratie te bevorderen. Stuwen in rivieren en grote waterlopen zijn zoveel mogelijk weggehaald en rivieren krijgen meer ruimte om water op te vangen en vast te houden. In gebieden waar via natuurlijke weg geen waterafvoer mogelijk is, is beregening verboden. Landbouw, woningbouw en scheepvaart ondervinden mogelijk nadelige effecten, maar passen zich hierop aan. Denk aan kleinere schepen, drijvende woningen en waterboerderijen.

\section{Hernieuwbare energie en koolstofvastlegging}

De overheid stuurt sterk op het verminderen van broeikasgassen. Zo moeten bewoners en bedrijven in het landelijk gebied voorzien in hun eigen duurzame energie. Dit doen zij door energie te besparen en door hernieuwbare energie op te wekken met zonnepanelen op daken, kleine windturbines of warmte-koude-opslag. Voor de energievraag van het stedelijk gebied, industrie en vervoer ontwikkelt de overheid energieparken. Hierbij werkt zij met een concessiemodel, waarbij bedrijven en energiecoöperaties de parken mogen ontwikkelen op aangewezen locaties. Voorbeelden zijn grote aqua- en geothermieprojecten op locaties waar het natuurlijk systeem genoeg

\section{OMGAAN MET KLIMAATVERANDERING}

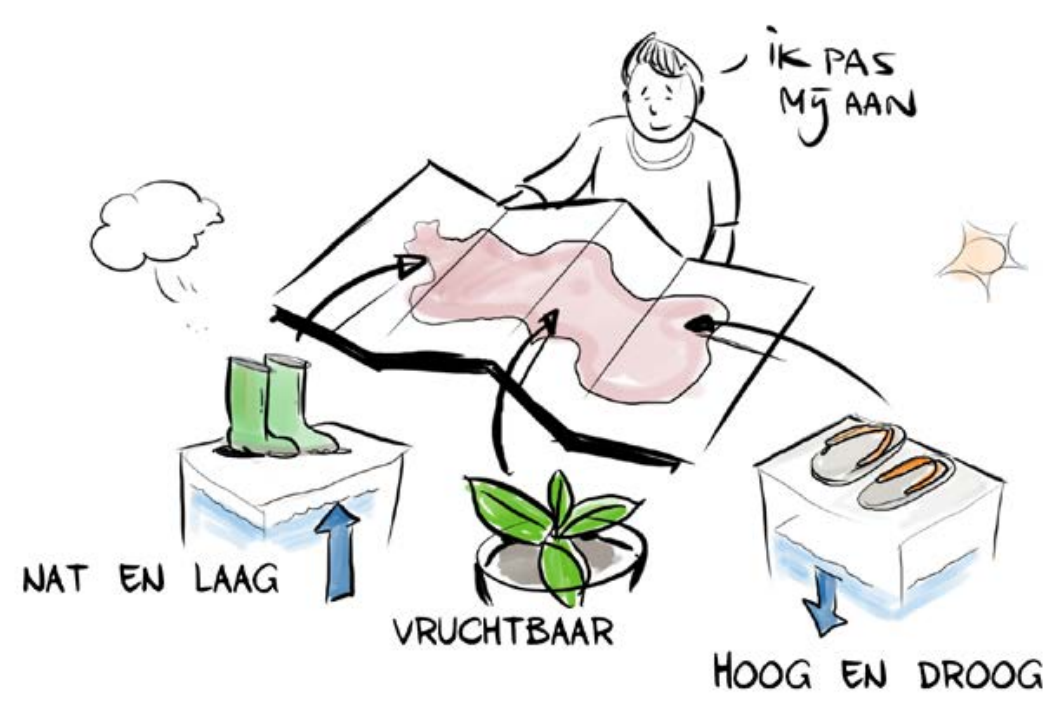

potentie heeft en waarbij de warmte gebruikt wordt voor industriële bedrijven en stadsverwarming. Op locaties met relatief veel wind, zoals Noordwest-Overijssel, komen windparken.

Door koolstof in het natuurlijk systeem op te slaan, worden onvermijdelijke emissies gecompenseerd. In veenweiden is broekbos en nieuw veen ontstaan waarmee koolstof wordt vastgelegd in plaats
Inhoud

Introductie

Vier toekomstperspectieven

1 Marktgedreven Overijssel

2 Samenwerkend Overijssel

3 Geregeld Overijssel

4 Natuurgestuurd Overijssel

Handelingsopties Handreiking

Vergelijking toekomstperspectieven

Colofon

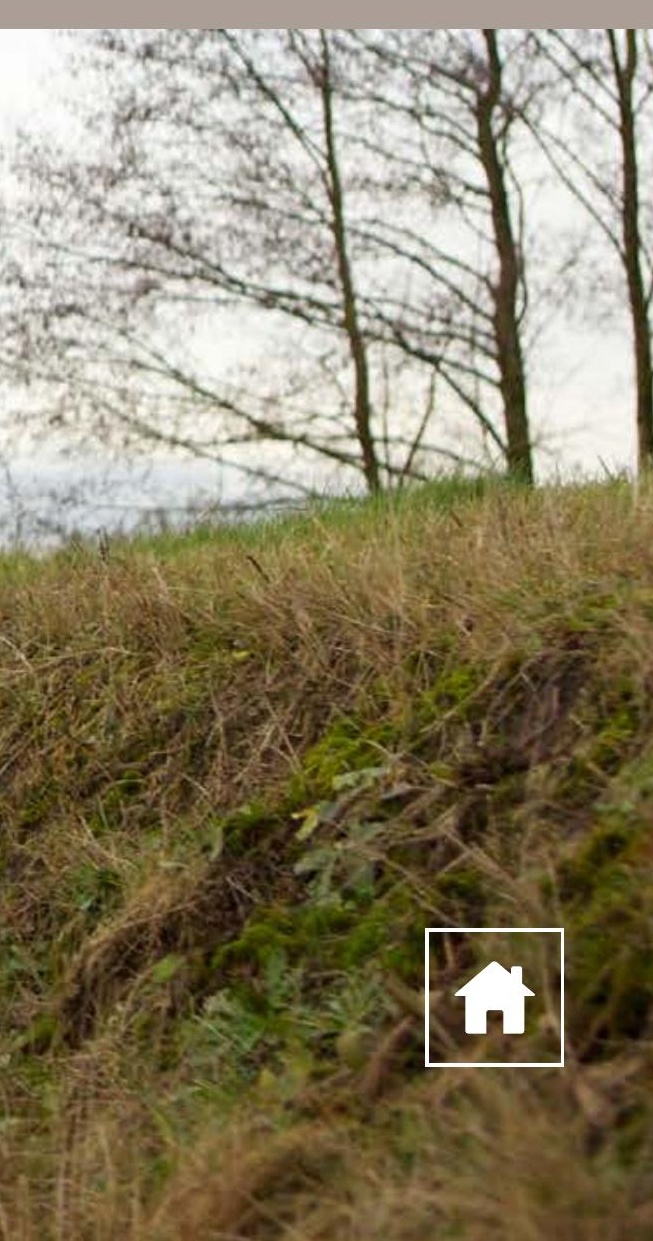


van uitgestoten. De overheid beloont bedrijven die het gehalte organische stof in de bodem weet te verhogen. Daarnaast legt de overheid klimaatbossen aan op locaties met geschikte natuurlijke omstandigheden.

\section{Gebiedsfonds: beloning voor diensten}

De overheid werkt met een gebiedsfonds om diensten van bedrijven en bewoners te belonen die bijdragen aan verduurzaming. Dit fonds wordt op verschillende manieren gevuld. Zo stelt de overheid bij concessies voor energieparken verplicht om een deel van de opbrengsten in het fonds te storten. Andere financieringsbronnen, zoals GLB-subsidies, Carbon Credits en toeristenbelasting, maken het fonds robuust.

\section{Natuur en biodiversiteit in Natuurgestuurd Overijssel}

\section{Dynamische natuur}

De overheid ontwikkelt en beheert de veerkrachtige, dynamische natuur op systeemniveau. Bestaande 'postzegels' zijn ingebed in grotere structuren. Natuurwaarden veranderen onder invloed van dynamische processen. $\mathrm{Er}$ is ruimte voor wilde, natuurlijke natuur en halfnatuurlijke natuur met extensieve landbouw. Hier vestigen zich spontaan soortenrijke leefgemeenschappen van wilde planten en dieren. Het is daarbij acceptabel dat sommige soorten door klimaatverandering verdwijnen en dat andere soorten daarvoor in de plaats komen. De wolf heeft zich in Overijssel gevestigd en vervult als toppredator een belangrijke rol in het ecosysteem. $\mathrm{Er}$ is ook plek voor grote wilde hoefdieren, zoals het edelhert en het wilde zwijn. De grote natuurgebieden zijn met elkaar verbonden, wat migratie van soorten mogelijk maakt.

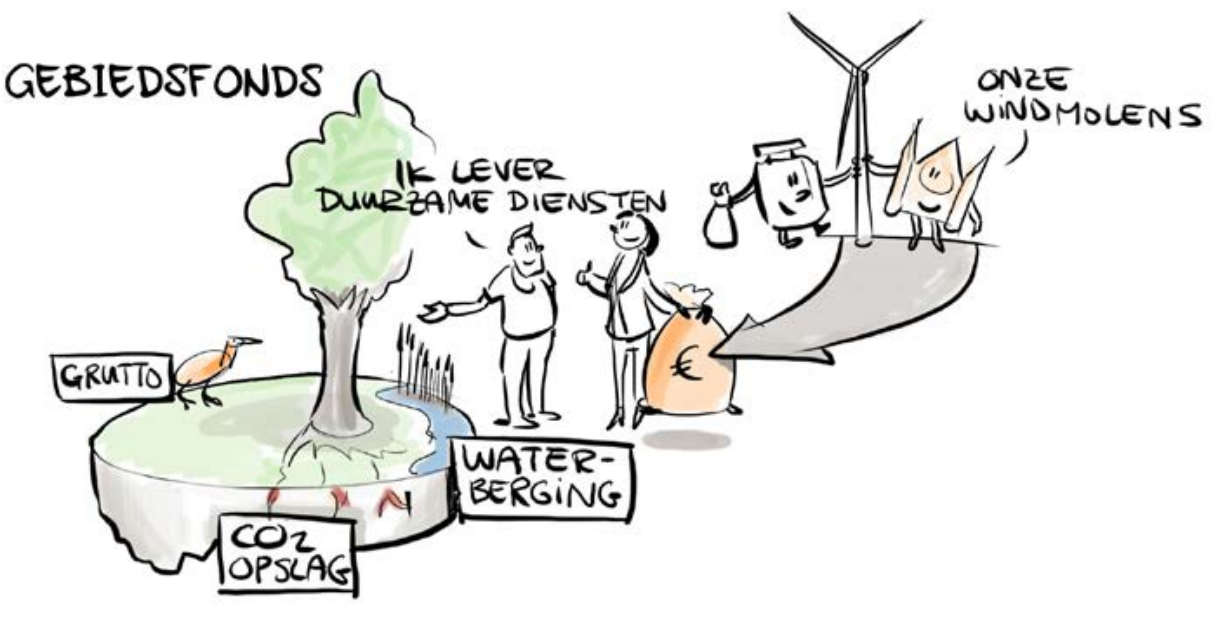

De overheid stimuleert bewoners en bedrijven van de natuur te genieten, maar reguleert wel het recreatief gebruikt om verstoring te voorkomen. Daarnaast stimuleert zij bewoners en bedrijven om consequent 'natuurinclusief' te handelen en daarbij ook gebruik te maken van de diensten die natuur en biodiversiteit bieden. Naast natuurinclusieve landbouw worden bijvoorbeeld ook de energieparken, waterbergingen en wegbermen natuurlijk ingericht. De grenzen tussen natuurgebieden en gebieden met andere functies in het landelijk gebied zijn daardoor vervaagd, wat goed is voor de biodiversiteit in het landelijk gebied.
Inhoud

Introductie

Vier toekomstperspectieven

\begin{tabular}{|c|c|}
\hline 1 & $\begin{array}{l}\text { Marktgedreven } \\
\text { Overijssel }\end{array}$ \\
\hline 2 & $\begin{array}{l}\text { Samenwerkend } \\
\text { Overijssel }\end{array}$ \\
\hline 3 & Geregeld Overijssel \\
\hline 4 & $\begin{array}{l}\text { Natuurgestuurd } \\
\text { Overijssel }\end{array}$ \\
\hline \multicolumn{2}{|c|}{ Handelingsopties } \\
\hline \multicolumn{2}{|c|}{ Handreiking } \\
\hline $\begin{array}{l}\text { Verg€ } \\
\text { toekc }\end{array}$ & $\begin{array}{l}\text { elijking } \\
\text { omstperspectieven }\end{array}$ \\
\hline
\end{tabular}

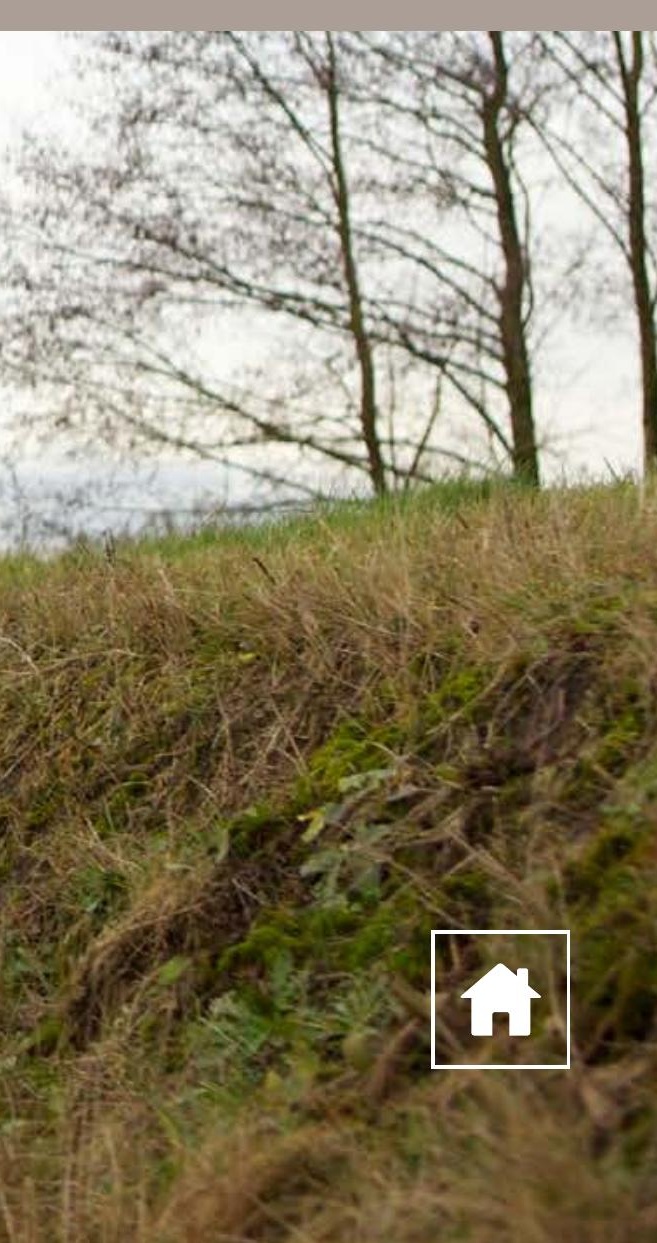




\section{Signalen uit de praktijk}

\section{Natuurlijk systeem benutten}

Building With Nature Vechtstromen

Waterschap Vechtstromen wil met het concept Building with Nature, oftewel Bouwen met Natuur, anticiperen op toekomstige uitdagingen in het waterbeheer. Kern van de aanpak is dat bij inrichtingsvraagstukken zoveel mogelijk gebruik gemaakt wordt van het natuurlijk potentieel in beken en rivieren. De waterkwaliteit en biodiversiteit kunnen hiermee op een efficiënte manier verhoogd worden terwijl wateroverlast beperkt wordt.

\section{Meer over Natuurlijk systeem benutten}

www.vechtstromen.nl
Transitie bekostigen

Zonneparken binnen het Ondernemend Natuurnetwerk Brabant Groen Ontwikkelfonds Brabant ontwikkelt businesscases die met behulp van opwekken van duurzame energie nieuwe natuur kunnen stimuleren. Een voorbeeld is het tijdelijk plaatsen van zonnepanelen op grond die in de toekomst bestemd is voor natuur. De opbrengsten van de zonnepanelen dienen gedurende 15 jaar als cofinanciering voor de ontwikkeling en bekostiging van de natuur. Daarnaast heeft het zonneveld gedurende de 15 jaar per hectare voor 160 huishoudens energie opgewekt. Na 15 jaar worden de panelen verwijderd en blijft natuur over.

\section{Meer over Transitie bekostigen}

www.groenontwikkelfondsbrabant.nl

\section{Inhoud}

Introductie

Vier toekomstperspectieven

\begin{tabular}{|c|c|}
\hline $\begin{array}{l}\text { Marktgedreven } \\
\text { Overijssel }\end{array}$ \\
\hline 2 Samenwerkend \\
Overijssel
\end{tabular}

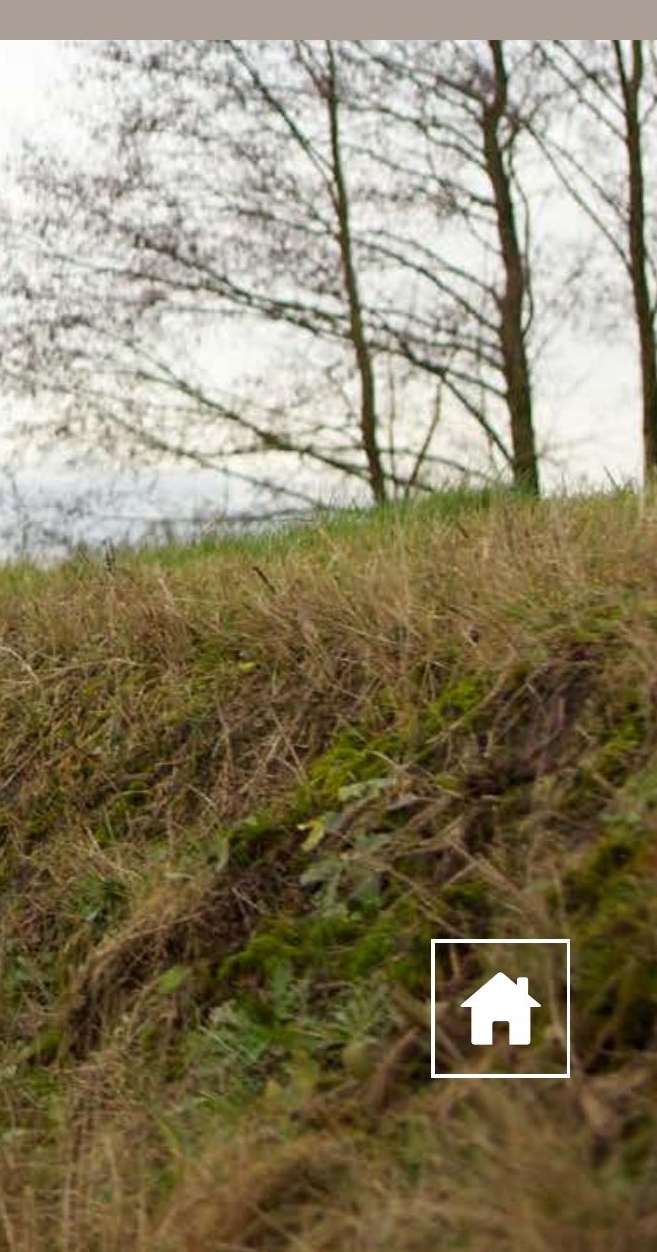




\section{Handelingsopties afgeleid uit toekomstperspectieven}

In dit hoofdstuk beschrijven we de uitkomsten van fase III. Hierbij redeneren we vanuit de toekomstperspectieven voor 2050 terug naar het heden. Dat maakt inzichtelijk welke veranderingen nodig zijn om huidige patronen en structuren te doorbreken. Daaruit leiden we vervolgens af welke handelingsopties de provincie binnen haar beleidsruimte heeft.

Het jaar 2050 lijkt nog ver weg. Toch zijn op korte termijn al stappen nodig om de duurzaamheidsopgaven in 2050 in samenhang gerealiseerd te hebben. De toekomstperspectieven bieden hier inspiratie voor. Door vanuit het toekomstperspectief terug te redeneren naar het heden (backcasting), ontdekken we welke stappen we in de tijd kunnen zetten. Dit vraagt een denkoefening. Per perspectief gaan we na wat de grootste verschillen zijn met de huidige situatie. Daardoor krijgen we in beeld op welke thema's verandering nodig is. En welke kwesties tussen het heden en het toekomstperspectief in staan. Op basis daarvan proberen we ons voor te stellen welke keuzes aan het toekomstperspectief voorafgingen en welke veranderingen zijn opgetreden (vanuit het gezichtspunt 2050 bekeken).

De keuzes en veranderingen verschillen per perspectief. In elk geschetst toekomstperspectief voor 2050 zijn de samenhangende opgaven voor verduurzaming van het landelijk gebied gerealiseerd. De wijze waarop verschilt fundamenteel. In elk perspectief zijn de functies landbouw \& voedsel, klimaat \& energie en natuur \& biodiversiteit heel anders ingevuld dan in 2019. Daardoor verschillen de stappen die in beeld komen door terug te kijken vanuit het toekomstperspectief naar het heden, per perspectief. Het resultaat is een breed pallet aan handelingsopties om het landelijk gebied te verduurzamen
Uit dat brede pallet leiden we vervolgens af welke handelingsopties de provincie op de korte termijn heeft binnen de beleidsruimte die de provincie heeft. Vervolgens kijken we welke vorm van sturing dat vraagt. Per perspectief formuleren we concrete suggesties voor activiteiten met een korte tijdshorizon. Zo werken we de eerste stappen uit waar de provincie nu al mee aan de slag kan.

De beleidsruimte van de provincie is beperkt door onder andere Europese en nationale kaders. Om de beweging te maken naar een duurzaam landelijk gebied, zijn naast de provincie uiteenlopende actoren nodig. Om besluiten te kunnen nemen over de gewenste ontwikkelingsrichting en bijbehorende handelingsopties, moet de provincie dus samenwerken met andere spelers.

In dit hoofdstuk doorlopen we voor elk perspectief de volgende vragen:

1 Welke stappen zijn gezet als het toekomstperspectief is gerealiseerd?

We kijken terug vanuit het toekomstperspectief naar de huidige situatie. Daarbij geven we aan welke stappen (denkbeeldig) zijn gezet als het toekomstperspectief is gerealiseerd.

2 Tot welke handelingsopties leiden deze voor de provincie op korte termijn?

We beschrijven de eerste stappen die nu door de provincie gezet kunnen worden om het toekomstperspectief te realiseren.
2 Samenwerkend Overijssel

3 Geregeld Overijssel

4 Natuurgestuurd Overijssel

Handreiking

Vergelijking toekomstperspectieven

Colofon

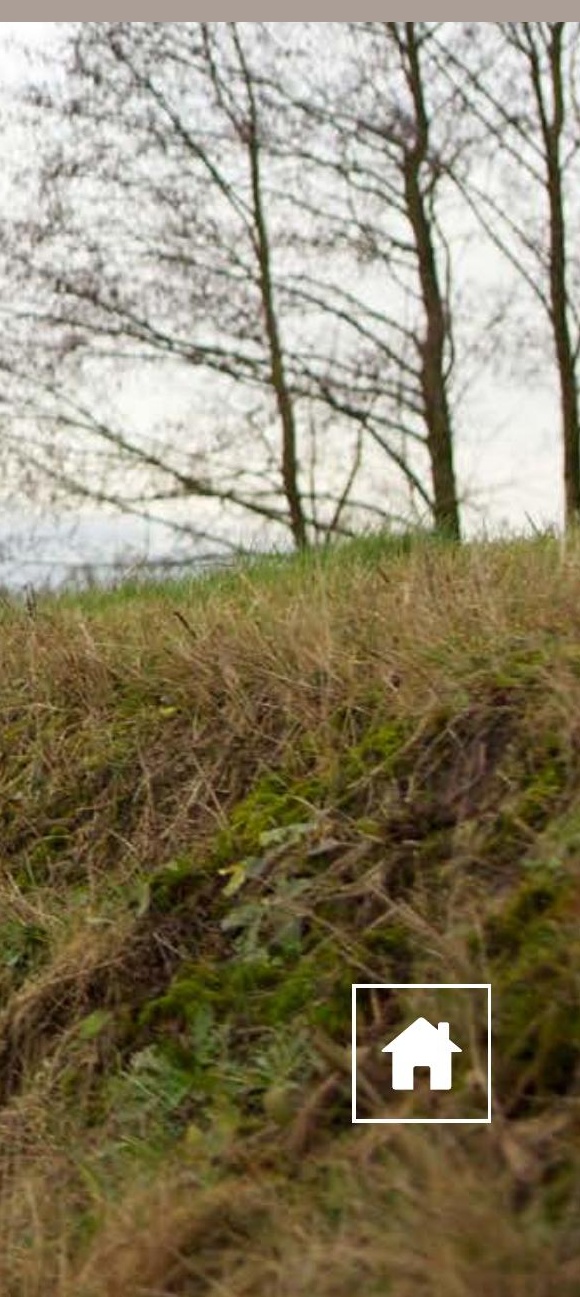




\section{Marktgedreven Overijssel}

\section{Welke stappen zijn gezet als het toekomstperspectief is gerealiseerd?}

In Marktgedreven Overijssel worden de verduurzamingsopgaven in het landelijk gebied gerealiseerd door private partijen. Steeds meer bedrijven beseffen dat klimaatverandering op lange termijn hun markten beïnvloedt en dat consumenten duurzaamheid steeds belangrijker vinden. Via de sturende kracht van marktwerking worden de opgaven zo efficiënt mogelijk opgelost. Private organisaties gaan sturen op kostenoptimalisatie, risicobeheersing en waardecreatie. Als dit toekomstperspectief is gerealiseerd, zijn de volgende stappen gezet:

Er is een klimaatneutrale voedsel- en energieketen tot stand gekomen

De huidige productie en consumptie van voedsel in Overijssel is onderdeel van een wereldwijd voedselsysteem. De organisatie daarvan wordt momenteel voornamelijk bepaald door economische afwegingen van partijen in het voedselsysteem, zoals winstmaximalisatie, beschikbaarheid grondstoffen, reputatie en vertrouwen. In Marktgedreven Overijssel gaat dit veranderen en wordt de opgave om het gehele systeem klimaatneutraal te maken, leidend. We zien een aantal tussenstappen die hier aan vooraf gingen:

\section{Er werden (inter)nationale afspraken gemaakt over klimaat-} neutraal produceren

Om voor bedrijven in een open economie een gelijk speelveld te creëren, wordt internationaal afgesproken dat alle voedsel- en energieproducten in 2050 klimaatneutraal aangeboden worden aan de consument. Dit is de stip aan de horizon waarmee de gehele (globale) voedsel- en energieketen, van primaire producent tot retail, de komende decennia kan reageren om klimaatneutraal te worden.

Er kwamen radicale innovaties tot stand voor voedselproductie Duurzaamheidsoplossingen komen nu vooral voort uit de klassieke innovatie met als doel, beter te doen wat we nu al doen. Voor de verduurzamingsopgaven in het landelijk gebied zit daar waarschijnlijk een grens aan. De koersverandering houdt in dat in 2050 wordt ingezet op wezenlijk andere producten of wezenlijk anders met elkaar samenwerken. Multidisciplinaire en sectoroverstijgende samenwer- king leidt tot een innovatieklimaat waarin baanbrekende oplossingen tot stand komen voor de huidige verduurzamingsopgaven.

\section{De macht van grote ketenpartijen werd ingeperkt door} kritisch tegenwicht vanuit de samenleving

Te verwachten is dat bedrijven die de meeste macht in de keten hebben, zoals internationaal opererende voedingsmiddelenconcerns, sterker zullen gaan sturen, opschalen of fuseren. Hierdoor kunnen de kleinere spelers in de keten, zoals de individuele agrariërs in Overijssel, in een zwakkere positie terecht komen. Er kunnen bijvoorbeeld extra duurzaamheidsinvesteringen worden afgedwongen om te mogen leveren. Daarnaast is het de vraag of deze internationale bedrijven voldoende sociale, culturele en politieke binding hebben met Overijssel om hier te willen investeren en of ze zich verantwoordelijk voelen voor een vitale en aantrekkelijke leefomgeving.

Door de verantwoordelijkheid voor duurzame productie geheel bij het bedrijfsleven te leggen, moeten inwoners en consumenten voldoende kritisch tegenwicht bieden, zodat dat bedrijven moeten investeren in een aantrekkelijke leefomgeving.

Marktpartijen bewezen publieke diensten te kunnen realiseren

In het huidige systeem neemt de overheid vaak de taak op zich om voor collectieve voorzieningen in de leefomgeving, zoals het wateren natuurbeheer, te zorgen. In Marktgedreven Overijssel is een deel van de activiteiten van drinkwaterbedrijven, netbeheerders en waterschappen overgenomen door private partijen. Er ontstaan nieuwe concepten zoals de klimaatverzekering of private natuurparken.

Privatisering van overheidsdiensten is niet altijd succesvol geweest. Voor een deel van de publieke diensten ontbreken de basisvoorwaarden voor een gezonde markt. Bijvoorbeeld omdat het ondernemersbelang botst met het publiek belang of omdat afnemers of aanbieders niet over keuzevrijheid beschikken. Zo is de huidige belangstelling van private partijen om te investeren in natuur vooral gericht op natuur met een economische betekenis. Het is bijvoor-
1 Marktgedreven Overijssel

2 Samenwerkend Overijssel

3 Geregeld Overijssel

4 Natuurgestuurd Overijssel

Handreiking

Vergelijking toekomstperspectieven Colofon (r) the
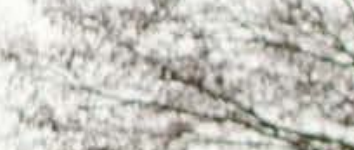
28.
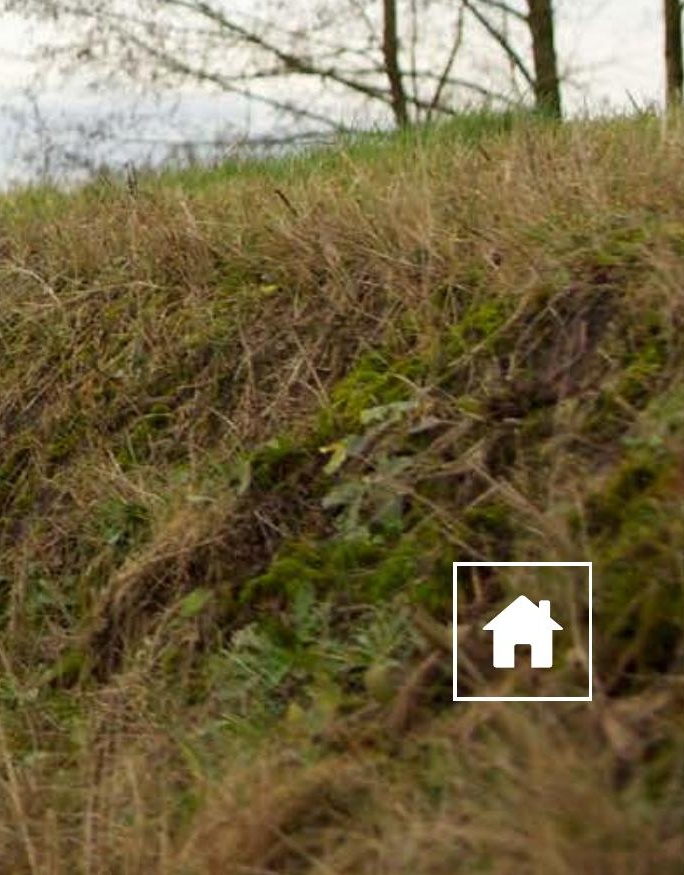
beeld denkbaar dat sommige natuur commercieel geëxploiteerd kan worden, gericht op kapitaalkrachtige consumenten of toeristen. In

\section{Handelingsopties voor de provincie}

Hiervoor beschreven we stappen die gezet zijn als het toekomstperspectief is gerealiseerd. In deze paragraaf beschrijven we per stap welke handelingsopties de provincie op korte termijn heeft.

Er is een klimaatneutrale voedsel- en energieketen tot stand gekomen

\section{Inzetten op internationale afspraken}

Investeerders en ondernemers hebben duidelijkheid voor de lange termijn nodig van de overheid. Dit vergt politieke en bestuurlijke duidelijkheid. Er zijn internationale afspraken nodig om een gelijk speelveld te creëren. Dit kan de provincie Overijssel niet zelf bepalen Wel kan ze hiervoor samen met andere overheden een lobby starten.

\section{Koplopers ondersteunen}

De provincie kan bedrijven stimuleren die nu al (willen) werken aan bijvoorbeeld een klimaatneutrale voedsel- of energieketen. Bijvoorbeeld door verschillende partijen bij elkaar te brengen (zoals ondernemers en kennisinstellingen), goede voorbeelden te promoten en belemmeringen in provinciale regelgeving weg te nemen. Dit vergroot betrokkenheid en draagvlak voor klimaatneutrale voedselproductie bij inwoners, bedrijven en overheden in Overijssel.

\section{Investeren in innovatie en creëren van marktkansen voor} baanbrekende oplossingen

De provincie kan het innovatieklimaat in Overijssel verder stimuleren en faciliteren. Ze kan partijen bij elkaar brengen en bijdragen aan multidisciplinaire, sectoroverstijgende samenwerkingsverbanden. Dit kan leiden tot het innovatieklimaat dat ruimte biedt voor baanbrekende oplossingen.

Via marktcreatie kan de provincie investeringen in innovatieve ontwikkelingen aantrekkelijker maken. Denk aan alternatieve eiwitproducten, gentech of het transparant maken van voedselketens met blockchaintechnologie. De provincie kan marktcreatie stimuleren met normstelling, regelgeving, grootschalige investeringsprogramma's, nieuwe financiële arrangementen inkoopprogramma's dat geval zal het natuuraanbod voor de stedelijke inwoners van Overijssel beperkter zijn.

en subsidies. Ook sociale innovatie vraagt aandacht. Nieuwe oplossingen vragen om gedragsverandering. Door deze inzet kan de provincie de kans ook vergroten dat baten van deze innovaties in Overijssel terechtkomen.

\section{Faciliteren van organisatie tegenwicht/macht}

Om tegenwicht te bieden aan de macht van dominante marktpartijen, zijn tegenkrachten in de samenleving nodig. De provincie Overijssel kan inwoners en consumenten daarin faciliteren. Bijvoorbeeld door het maatschappelijke middenveld te ondersteunen dat zich richt op de verduurzamingsopgaven in het landelijk gebied of door goede consumenteninformatie te garanderen. De overheid kan zelf ook kaders stellen. Bijvoorbeeld voor strategische omgevingsmanagement waamee bedrijven zelf draagvlak zoeken voor hun beoogde activiteiten. Overheidskaders kunnen specificeren waar draagvlak in de omgeving aan moet voldoen en op welke manier publieke belangen op de lange termijn gewaarborgd kunnen blijven.

Marktpartijen bewezen publieke diensten te kunnen realiseren

Experimenteren met publieke diensten door private partijen De provincie kan private initiatieven die zich aandienen ondersteunen. Dit kunnen zeer kleinschalige initiatieven zijn, zoals een proef met tegeltaks voor verharde tuinen, maar ook grootschalige, zoals private natuurparken. Op basis van de experimenten met privatisering van publieke diensten ontstaat inzicht in wat wel en niet werkt. Door deze systematisch te evalueren wordt duidelijk welke basisvoorwaarden gelden voor een geslaagde marktwerking in de publieke sector, welke diensten zich hiervoor lenen en welke publieke belangen er gewaarborgd moeten worden. Het hoeft overigens niet altijd een volledige privatisering te zijn. De provincie kan ook onderzoeken bij welke publieke diensten marktpartijen een grotere rol kunnen spelen. Voorbeeld: de overheid kondigt een asbestverbod af en verzekeraars passen risicoprofielen aan. De provincie en het bedrijfsleven kunnen experimenteren met dit soort samenwerkingsverbanden.

1 Marktgedreven Overijssel

2 Samenwerkend Overijssel

3 Geregeld Overijssel

4 Natuurgestuurd Overijssel

Handreiking

Vergelijking toekomstperspectieven Colofon
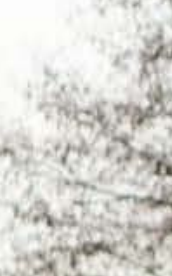

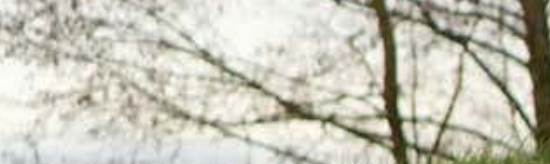

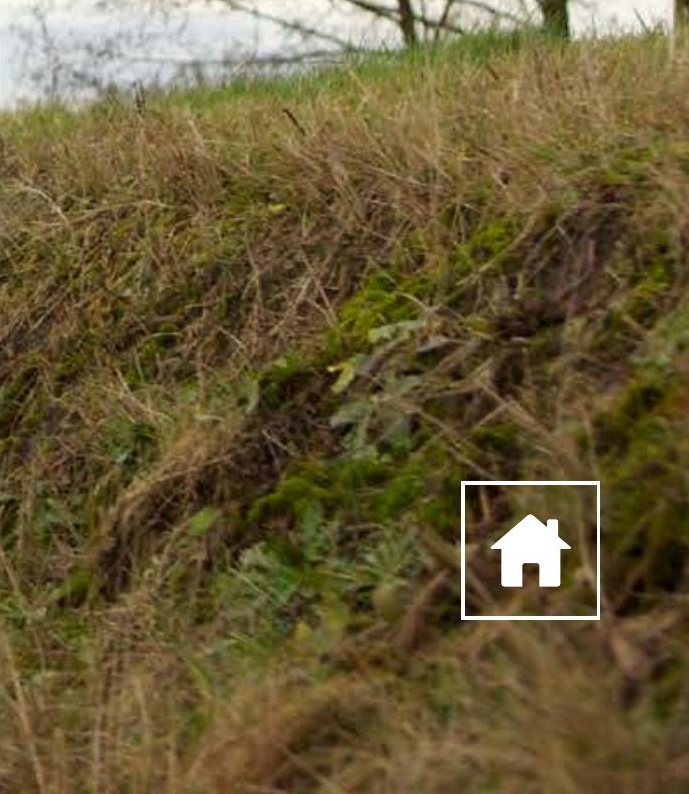




\section{Samenwerkend Overijssel}

\section{Welke stappen zijn gezet als het toekomstperspectief is gerealiseerd?}

In Samenwerkend Overijssel werken de lokale gemeenschappen samen om voedsel en energie te produceren en voor de natuur te zorgen. De bewoners en bedrijven in deze lokale gemeenschappen nemen daarvoor zelf het initiatief omdat ze zich (mede)eigenaar voelen van één of meerdere maatschappelijke opgaven. We gaan van een commerciële aanpak, waar winstmaximalisatie centraal staat, naar een coöperatieve gedachte: als je het samen doet, levert het voor iedereen wat op.

Er zijn momenteel al verschillende voedsel- en energiecoöperaties in Overijssel. Deze huidige initiatieven zijn nog vaak kleinschalig, zeer lokaal en kennen vaak een enkelvoudige insteek. Als het toekomstperspectief Samenwerkend Overijssel is gerealiseerd zijn de volgende stappen en tussenstappen gezet:

Lokale gemeenschappen zijn zelfsturend geworden en maatschappelijke initiatieven zijn geprofessionaliseerd De overheid bepaalt in de huidige situatie op welke manier het landelijk gebied wordt ingericht en hoe de activiteiten in het landelijk gebied zich manifesteren. Als dit toekomstperspectief is gerealiseerd, hebben lokale gemeenschappen zeggenschap over hun eigen landelijk gebied en nemen ze zelf de verantwoordelijkheid om de toekomstige opgaven in het landelijk gebied op te pakken. Denk aan de productie van voedsel, schoon water en energie.

We zien een aantal tussenstappen die hier aan vooraf gingen:

Maatschappelijke initiatieven kregen meer positie en toegang tot geld, grond en kennis

Momenteel hebben maatschappelijke initiatieven een achterstand vergeleken met de gevestigde orde van marktpartijen en overheden. Initiatieven hebben beperkt toegang tot kennis, kapitaal en grond. Om tot opschaling van de maatschappelijke initiatieven te komen, is een ombuiging nodig. Hiervoor zijn nieuwe samenwerkingsvormen, verdienmodellen en juridische afspraken nodig tussen de grondeigenaren en de initiatieven. Initiatieven krijgen daarmee beter toegang tot grond (bijvoorbeeld pacht), kennis (bijvoorbeeld juridische kennis) en kapitaal (bijvoorbeeld revolverende fondsen) om maatschappelijke doelen te realiseren.

\section{Het organiserend vermogen van initiatieven nam toe en} professionaliseerde.

Maatschappelijke opgaven in het landelijk gebied zijn best ingewikkeld, omdat er sprake kan zijn van verschillende belangen die wel of niet met elkaar te verenigen zijn. Bij een verdere opschaling van de initiatieven vergt dit veel organiserend vermogen van lokale gemeenschappen. In dit perspectief ontstaan er nieuwe organisatiemodellen met nieuwe vormen van coöperatieve samenwerking en participatie- en (be)stuursvormen van bewoners en bedrijven om de maatschappelijke initiatieven te professionaliseren en verder op te schalen. Denk bijvoorbeeld aan collectieven die samen landbouwgronden gebruiken of duurzame energie produceren.

Via grondgebruik is maatschappelijke meerwaarde gegenereerd

Het grondgebruik van bedrijven kent momenteel een economische focus gericht op zo hoog mogelijke rendementen halen. Dit is ook zo bij nieuwe ontwikkelingen als opwekking van duurzame energie. Lokale maatschappelijke waarden spelen daarin maar beperkt een rol. Daar komt bij dat ook diensten van het natuurlijk systeem in de huidige samenleving min of meer als vanzelfsprekend ervaren worden en het economisch belang daarvan niet wordt gekwantificeerd. Denk aan drinkwater, voedsel, schone lucht, grondstoffen, bestuiving van gewassen, koolstofvastlegging en een mooie omgeving om te recreëren. In Samenwerkend Overijssel staan juist de maatschappelijke waarden waar de lokale gemeenschappen aan hechten centraal. Deze waarden werken door in het grondgebruik en de regionale economie.

We zien een aantal tussenstappen die hier aan vooraf gingen:

Een sterkere binding tussen stad en platteland, zorgde voor een sterkere regionale economie binnen de wereldeconomie. In Samenwerkend Overijssel wordt lokaal voor iedereen voedsel en
Inhoud

Introductie

Vier toekomstperspectieven

Handelingsopties

1 Marktgedreven Overijssel

2 Samenwerkend Overijssel

3 Geregeld Overijssel

4 Natuurgestuurd Overijssel

Handreiking

Vergelijking toekomstperspectieven Colofon
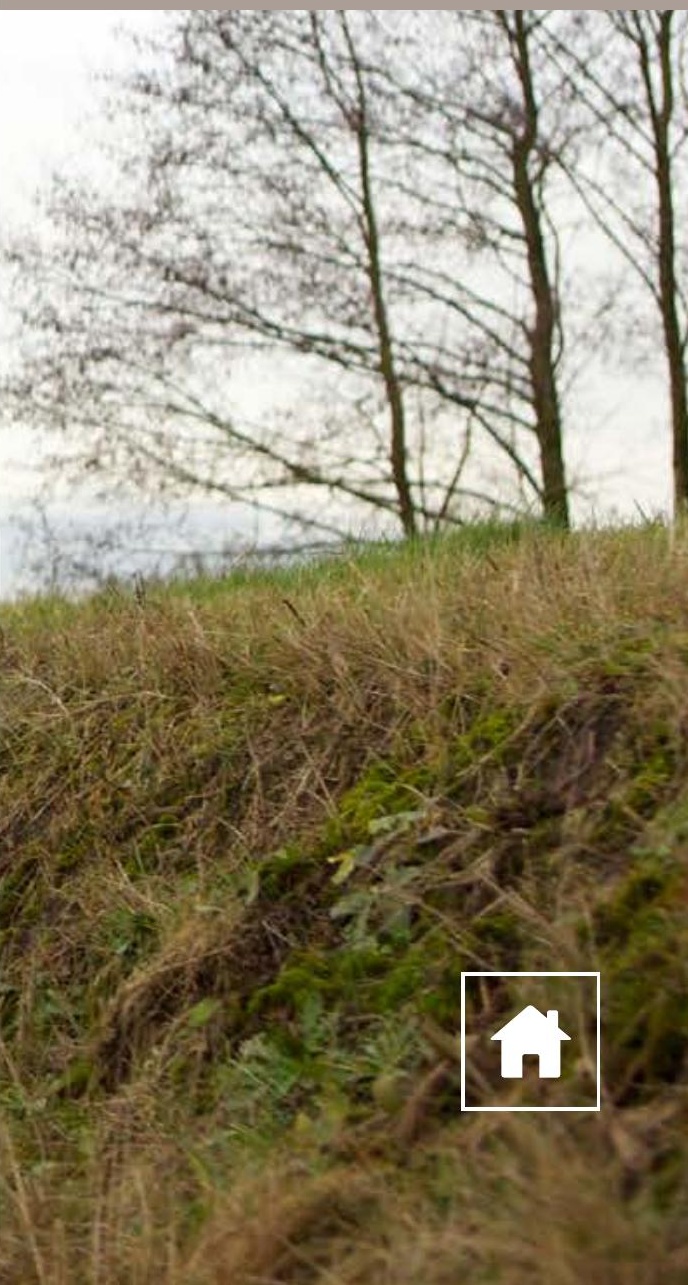
energie geproduceerd. Daarvoor is nodig dat er een regionale economie ontstaat met een sterke binding tussen de regionale producenten en de afnemers, die vaak in het stedelijk gebied wonen. Stedelingen zijn bereid een meerprijs te betalen om het landelijk gebied mooi en duurzaam te houden. Er ontstaat een sterke regionale wederkerige relatie waarin diensten en producten tussen stad en platteland worden uitgewisseld.

Initiatieven kregen inzicht in mogelijkheden om het natuurlijk systeem zowel duurzaam als economisch te benutten

Het natuurlijk systeem is het uitgangspunt voor het grondgebruik in de lokale gemeenschappen. Inzicht in hoe deze gemeenschappen deze lokale natuurlijke omstandigheden zo goed mogelijk kunnen benutten, ontbreekt vaak. Verder is het niet vanzelfsprekend dat ze werken in balans met het natuurlijk systeem. Zo kan een energiecooperatie zonnepanelen plaatsen, zonder daarbij rekening te houden met de gevolgen voor bodemkwaliteit, biodiversiteit of waterbeheer. $\mathrm{Er}$ is ook kennis nodig om de (ecosysteem)diensten die het natuurlijk systeem biedt, goed te verwaarden. Is bijvoorbeeld duurzame energieproductie te combineren met ontwikkeling van natuurwaarden of opslaan van koolstof en is het mogelijk voor zowel energieproductie als de natuurontwikkeling een beloning te krijgen?

In dit perspectief worden de diensten van het natuurlijk systeem benut om verduurzamingsopgaven in samenhang op te pakken en kunnen lokale gemeenschappen waarde aan deze (ecosysteem) diensten toekennen.

\section{Welke handelingsopties voor de provincie leiden we hieruit af?}

Hiervoor beschreven we stappen die gezet zijn als het toekomstperspectief is gerealiseerd. In deze paragraaf beschrijven we per stap welke handelingsopties de provincie op korte termijn heeft.

Lokale gemeenschappen zijn zelfsturend geworden en maatschappelijke initiatieven zijn geprofessionaliseerd

Toegang tot resources bieden: stimuleer en faciliteer maatschappelijk initiatieven gericht op duurzaam grondgebruik Maatschappelijke initiatieven hebben baat bij professionalisering, toegang tot kennis en (productie)middelen om te kunnen opschalen. De provincie kan maatschappelijke initiatieven, bedrijven en (gebieds)coöperaties, die zich richten op duurzaam grondgebruik vóór en dóór de lokale gemeenschappen, stimuleren en faciliteren. Zo kan de provincie grond beschikbaar stellen aan initiatieven en ze toegang geven tot kapitaal en kennis. Ook kan de provincie als 'launching customer' initiatieven toegang geven tot de markt. Om de toegang voor initiatieven tot de provinciale organisatie te vergroten, kunnen 'grenswerkers', zoals gebiedsregisseurs, aanjagers of coaches, aangesteld worden. Zij kunnen een brug vormen tussen de wereld van de initiatieven en die van overheden. Deze grenswerkers kunnen vragen vanuit de initiatieven uitwerken en doorvertalen naar acties van verschillende beleidsafdelingen binnen de provincie of andere overheden. Dit omdat vragen vanuit de praktijk vaak over de sectorale beleidsgrenzen heen gaan en toegang tot 'de overheid' daardoor complex en frustrerend kan zijn

\section{Lerend vermogen ondersteunen}

De provincie kan voor een verdere professionalisering het lerend vermogen van maatschappelijke initiatieven ondersteunen door bijvoorbeeld leernetwerken te organiseren. Uitdagingen vormen daarbij de complexiteit van de duurzaamheidsopgaven en het orgainzet op monitoring en evaluatie van de initiatieven. Niet om topdown te sturen, maar om goed zicht te krijgen op wat deze initiatieven nodig hebben. Hoe creëer je bijvoorbeeld een gelijk speelveld? In welke mate dragen de initiatieven bij aan de verduurzamingsopgaven in het landelijk gebied? En zijn er beleidskaders nodig om zogenoemde 'freeriders' te voorkomen?

Via grondgebruik is maatschappelijke meerwaarde gegenereerd

\section{Ontwikkeling korte ketens ondersteunen}

Het grondgebruik staat ten dienste van de maatschappelijke meerwaarde voor de lokale gemeenschap. De bewoners en bedrijven die voor initiatiefnemers. niserend vermogen. Daarnaast is het van belang dat de provincie

1 Marktgedreven Overijssel

2 Samenwerkend Overijssel

3 Geregeld Overijssel

4 Natuurgestuurd Overijssel

Handreiking

Vergelijking toekomstperspectieven Colofon

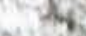
$7 x^{2}$

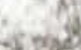

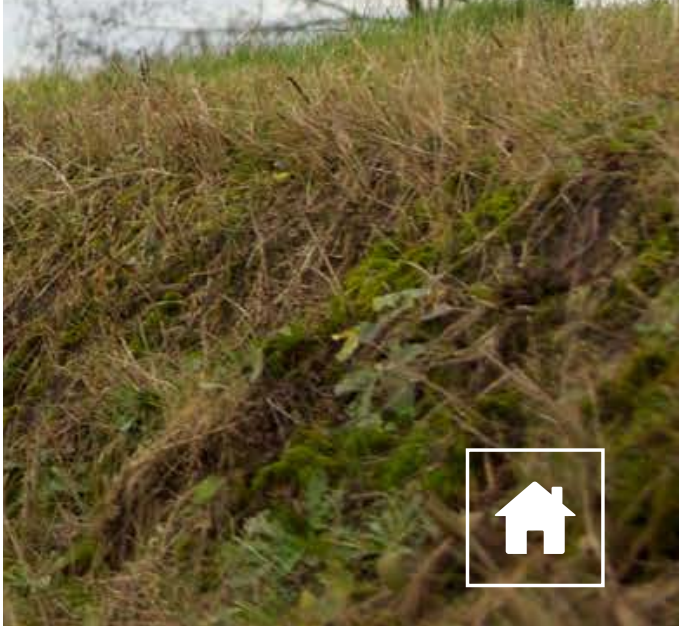


deze diensten leveren, maken optimaal gebruik van het natuurlijk systeem en verdienen hiermee een goed inkomen. De sleutel om deze stap te maken ligt in een stevigere verbinding tussen stad en landelijk gebied en in korte ketens op lokaal niveau. De provincie kan de ontwikkeling faciliteren. Bijvoorbeeld agro- en foodondernemers die een goede businesscase in de markt willen zetten te helpen met de ontwikkeling van proof-of-concept. Of door innovatielabs te organiseren voor de ontwikkeling van waardevolle voedselketens.

\section{Kennis delen over werking natuurlijk systeem}

Bedrijven en inwoners nemen in dit toekomstperspectief zelf meer verantwoordelijkheid op zich voor taken die nu nog bij overheden rusten. Denk aan het beheren van het lokale watersysteem, het creëren van natuurwaarden of het produceren van hernieuwbare energie. De kennis die de provincie voor deze taken heeft opgebouwd, kan zij delen met de maatschappelijke partijen. Vervolgens kan zij samen met deze partijen afspraken maken over taken en verantwoordelijkheden. Dit kan ook leiden tot nieuwe bestuurs- en organisatievormen die zich richten op de verduurzamingsopgaven, zoals collectieven, gebiedscoöperaties of nieuwe vormen van gemeenschappelijk grondgebruik. De provincie kan samen met maatschappelijke partijen met deze nieuwe vormen experimenteren.
Experimenteren met het benutten van het natuurlijke systeem als onderdeel van economisch beleid

Initiatieven waarbij natuur en economie elkaar versterken, brengen innovaties op gang en zorgen voor maatschappelijke winst. Hoewel er enkele pioniers zijn, is deze winst in praktijk, vanuit economisch perspectief, nog moeilijk te verwaarden. Het ontbreekt vaak aan kennis en ons huidige economische model biedt maar beperkt ruimte om de waarde van de, door het natuurlijke systeem geleverde, diensten te meten en mee te wegen op de economische balans. De provincie kan experimenteerruimte bieden binnen de beleidsruimte die ze heeft voor bedrijven, natuurorganisaties en burgers die kansen voor bescherming én benutting van het natuurlijke systeem willen uitbouwen tot een duurzaam verdienmodel. De provincie kan daarbij ook monitoren of de nieuwe aanpak leidt tot biodiversiteitswinst. Verder kan de provincie met andere overheden in gesprek of kan er via andere beleidssporen bevorderd worden dat de waarde van het natuurlijke systeem meegewogen wordt in het economisch beleid. Denk aan belastingen of true pricing van producten.
Inhoud

Introductie

Vier toekomstperspectieven

Handelingsopties

1 Marktgedreven Overijssel

2 Samenwerkend Overijssel

3 Geregeld Overijssel

4 Natuurgestuurd Overijssel

Handreiking

Vergelijking toekomstperspectieven

Colofon

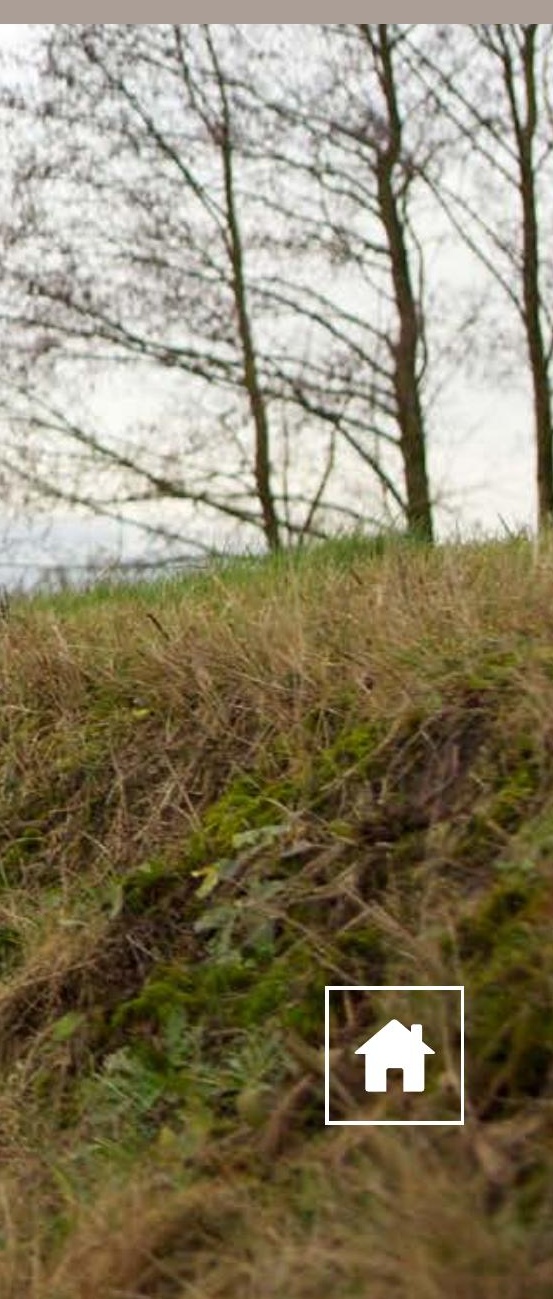




\section{Geregeld Overijssel}

\section{Welke stappen zijn gezet als het toekomstperspectief is gerealiseerd?}

In Geregeld Overijssel neemt de overheid het heft in handen door integraal en planmatig beleid op economisch, ruimtelijk en sociaal gebied. De overheid stelt duidelijke kaders en nodigt bedrijven en bewoners uit om die in te vullen. Waar nodig onderneemt ze zelf actie. De overheid stelt vast wat duurzaam en gezond voedsel is en biedt planologische duidelijkheid over waar grootschalig voedsel en energie geproduceerd kan worden en waar er ruimte is voor natuur. Als dit toekomstperspectief is gerealiseerd, zijn de volgende stappen gezet:

Er is een integrale sturing op een duurzaam en gezond voedselsysteem tot stand gekomen

In de huidige situatie wordt vanuit verschillende beleidsvelden en op verschillende schaalniveaus aan verduurzaming van het voedselsysteem gewerkt. Dit gebeurt vooral selectief op onderdelen van het voedselsysteem. Dit kan leiden tot een eenzijdige sturing op één aspect, met nadelige gevolgen voor een ander aspect. Bij een eenzijdige focus op bijvoorbeeld $\mathrm{CO}_{2}$ raakt buiten beeld dat de productie en consumptie ook gevolgen hebben voor gezondheid, bodemkwaliteit, voedselzekerheid, landschap en biodiversiteit. In Geregeld Overijssel, waarin voedselproductie als een nutsvoorziening wordt beschouwd, stuurt de overheid integraal op verduurzaming van het gehele voedselsysteem.

We zien een aantal tussenstappen die hier aan vooraf gingen:

\section{Blinde vlekken kwamen in beeld: sturing op ander aspecten} dan landbouw

Naast de duurzaamheidsopgaven voor de landbouw, komen ook andere sturingsknoppen voor de overheid in beeld zoals voedselverspilling en het eetpatroon van de consument. In een integraal voedselbeleid worden deze sturingsknoppen in samenhang met sturingsknoppen voor duurzame landbouw beschouwd. Door beïnvloeding van consumentengedrag wordt voedselverspilling tegengegaan en een gaan mensen duurzamer en gezonder eten. Dit werkt door in de wijze van produceren.

\section{Milieu en gezondheidskosten van voedselproductie kwamen} in beeld

Om inzicht in de noodzaak en acceptatie van ingrepen in de voedselproductie te vergroten, brengt de overheid maatschappelijke kosten in beeld die gepaard gaan met de huidige voedselproductie. Denk aan de gezondheidskosten als gevolg van ongezonde voedingspatronen en maatschappelijk kosten van milieubelastende voedselproductie. Hiermee kan de overheid onderbouwen dat andere keuzes nodig zijn vanuit duurzaamheidsoogpunt én om maatschappelijke kosten te beperken.

De overheid ging planmatiger sturen met doorzettingsmacht

In de huidige situatie is er sprake van een complex krachtenveld met vele spelers. Deze bewegen niet allemaal dezelfde kant op en hebben eigen afwegingsruimte. Dat maakt het lastig om een stap te zetten in verduurzaming van het voedselsysteem, het realiseren van de duurzame energieopgave of de gewenste natuur. In Geregeld Overijssel zet de overheid in op versnelling van de transities door de opgaven als een zaak van provinciaal belang te beschouwen en hier stevig en met de benodigde doorzettingsmacht op te sturen.

We zien een aantal tussenstappen die hier aan vooraf gingen:

De overheid nam via het ruimtelijke beleid de regie om voldoende ruimte te bieden voor de voedsel, energie en natuuropgaven.

Om de verduurzamingsopgaven in het landelijk gebied te realiseren wordt vaak de strategie gehanteerd waarbij de afzonderlijke overheden hun eigen afwegingsruimte behouden en decentrale overheden zelf integrale afwegingen kunnen maken. Burgers en bedrijven kunnen zelf het initiatief tonen of aangemoedigd worden om (een deel van) de opgave te realiseren. Op microniveau is de samenleving dan bezig met het zoeken van oplossingen en worstelt iedereen met de complexiteit van de opgaven. In Geregeld Overijssel neemt de overheid een sterke regierol in de ruimtelijke ordening. Er wordt ruimte gecreëerd voor de diverse opgaven:
1 Marktgedreven Overijssel

2 Samenwerkend Overijssel

3 Geregeld Overijssel

4 Natuurgestuurd Overijssel

Handreiking

Vergelijking toekomstperspectieven Colofon
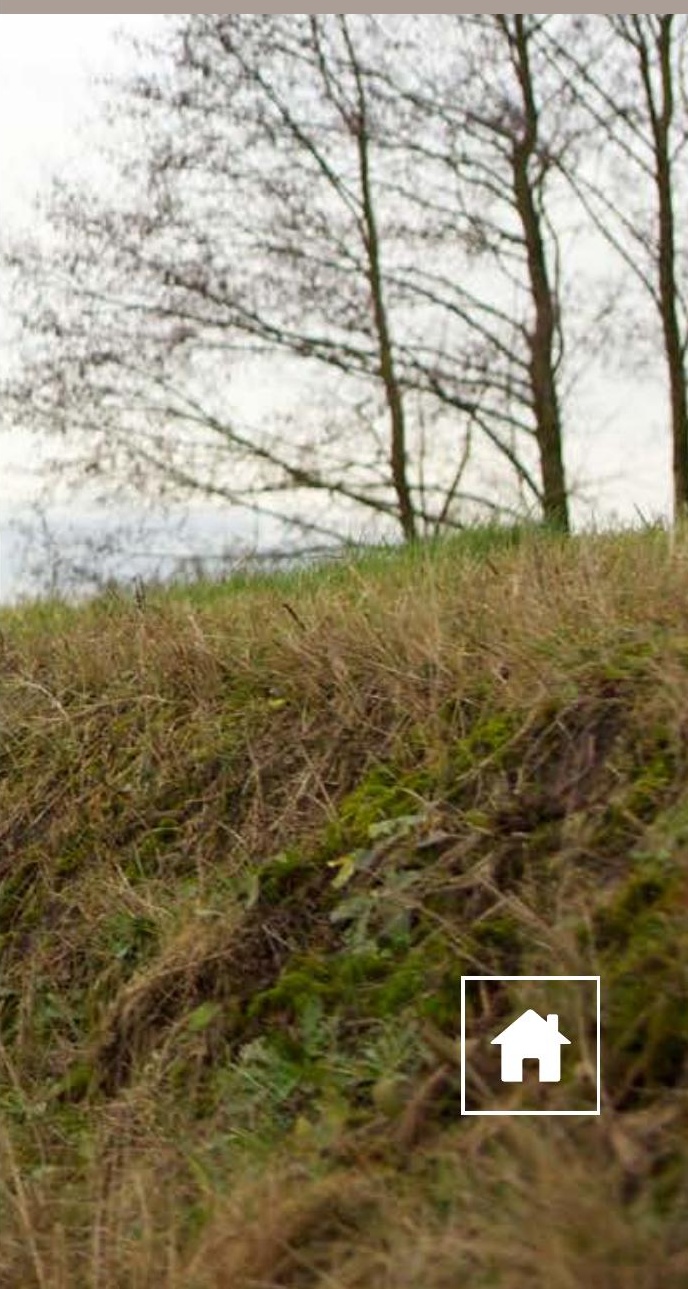
een energiehoofdstructuur voor grootschalige energieopwekking, een agrarische hoofdstructuur met ruimte voor grondgebonden landbouw, grootschalige agrofoodparken met concentraties van intensieve landbouw en verwerking en een ecologische hoofdstructuur met ruimte voor natuur

\section{De overheid ging meer ondernemen}

In de huidige situatie worden de verduurzamingsopgaven met name door private partijen gerealiseerd. Energie wordt opgewekt door particulieren, coöperaties en bedrijven en de voedselketen is volledig in handen van private partijen. De overheid faciliteert, reguleert en houdt toezicht. In dit perspectief grijpt de overheid actief in om marktfalen rond verduurzamingsopgaven te herstellen. Ze heeft de regie zelf in handen genomen om de opgaven te realiseren. De overheid is gaan ondernemen. Er wordt meer in publiekrechtelijke of privaatrechtelijke organisaties gewerkt, waarin de overheid zowel een bestuurlijk als een risicodragend financieel belang heeft. De overheid staat daarmee zelf aan het roer van de verduurzamingsopgaven. De overheid blijft volledig verantwoordelijk voor het beschermen van natuur, landschap en biodiversiteit.

\section{Bedrijven en bewoners gingen koers overheid meer accepteren}

In Geregeld Overijssel worden de individuele (keuze)vrijheden van

\section{Handelingsopties voor de provincie}

In Geregeld Overijssel stuurt de overheid op een maakbare samenleving door actief overheidsingrijpen, middels reguleren, initiatief te nemen en het creëren van doorzettingsmacht. Er is sprake van een grote overheid die veel taken op zich neemt en regelt voor haar inwoners. De provincie kan nu met de volgende concrete handelingsopties starten:

Er is een integrale sturing op een duurzaam en gezond voedselsysteem tot stand gekomen

\section{Inzetten op nieuwe aspecten van de verduurzaming van het} voedselsysteem

De provincie kan inzetten op het tegengaan van voedselverspilling het bevorderen van een duurzaam en gezond eetpatroon van consu- de inwoners en bedrijven in Overijssel beperkt door sterke overheidssturing. Risico hiervan is dat het maatschappelijk bewustzijn voor de opgaven naar de achtergrond verdwijnt. Ook het ingrijpen op de keuzevrijheid van consumenten kan tot weerstand leiden. $\mathrm{Bij}$ een sterke overheidsturing bestaat het risico dat ondernemerschap en creativiteit afneemt en dat inwoners weinig prikkels krijgen om zelf in actie te komen of te vernieuwen. Het kan leiden tot hogere belastingen en duurdere producten. In dit perspectief zet de overheid daarom sterk in op (stapsgewijze) maatschappelijke acceptatie voor het handelen van de overheid en worden door de prikkels ontwikkeld om ondernemerschap en creativiteit aan te jagen.

\section{Er zijn buffers gecreëerd om risico's op te vangen}

In dit perspectief zijn technologische maatregelen genomen om duurzaamheidsopgaven te realiseren. Technologische systemen hebben beperkingen. Sommige systemen bieden tijdelijke oplossingen, denk aan onderwaterdrainage in het veenweidegebied of de technische ingrepen in natuurgebieden. De systemen zijn ook kwetsbaar voor verstoringen, bijvoorbeeld cyberaanvallen. En ten slotte zijn technische oplossingen vaak gericht op enkelvoudige problemen en veroorzaken ze soms weer andere problemen. In dit perspectief kent de overheid de beperkingen van de technologie en bouwt buffers in om risico's bij falen van technische oplossingen op te vangen.

menten en verduurzaming van voedselproductie. Ze kan hierin samenwerken met regionale partners en het Rijk. Sturingsmogelijkheden zijn regelgeving, financiële prikkels en nudging. Dit vraagt ook nieuwe partners en nieuwe coalities. Denk bijvoorbeeld aan samenwerking met gezondheidszorg- en welzijnsorganisaties of met private spelers die veel invloed hebben in de voedselketen, zoals de retail.

\section{Analyse uitvoeren om kosten en baten van een gezond en} duurzaam voedselsysteem in beeld te brengen

De provincie kan in samenwerking met het Rijk een analyse uitvoeren om in beeld te brengen wat de baten zijn van een gezond en duurzaam voedselsysteem, zoals vermeden kosten gezondheidszorg en baten verduurzaming. Deze baten kunnen worden afgezet tegen de kosten en baten van het huidige voedselsysteem.
1 Marktgedreven Overijssel

2 Samenwerkend Overijssel

3 Geregeld Overijssel

4 Natuurgestuurd Overijssel

Handreiking

Vergelijking toekomstperspectieven Colofon s.

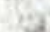
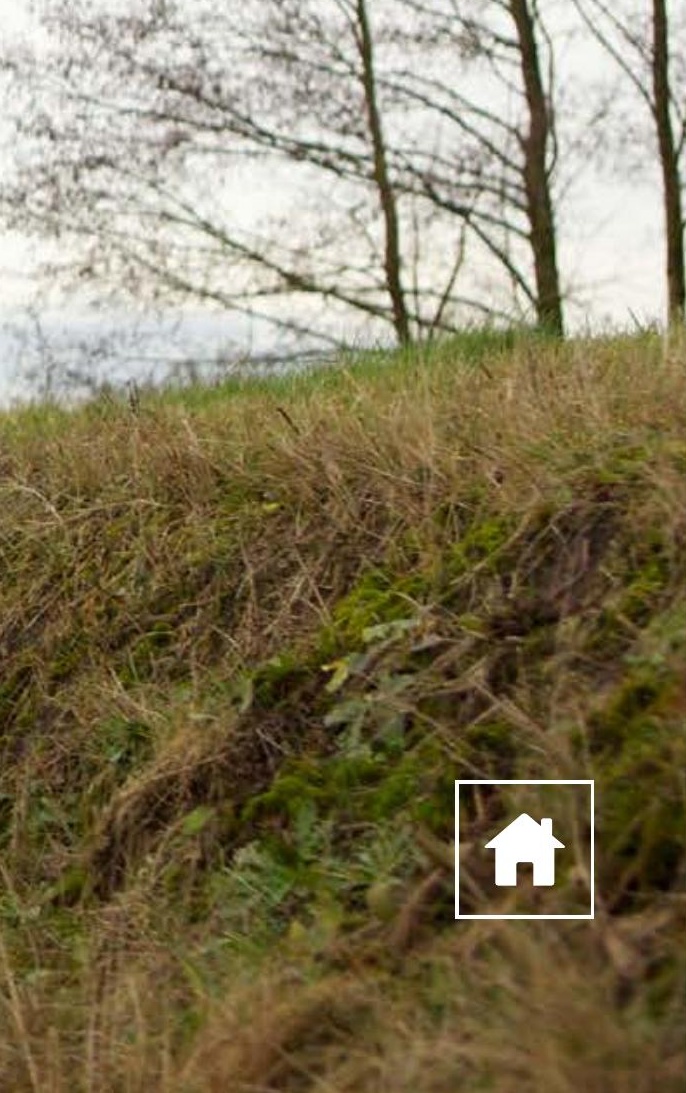


\section{Inzetten op bewustwording bij consumenten}

Om de inwoners van Overijssel te doordringen van de noodzaak van een gezond- en duurzaam voedselpatroon kan de provincie Overijssel als eerste stap samen met haar partners inzetten op bewustwording bij consumenten. Via nudging kunnen consumenten meegaan in een duurzaam en gezond voedselpatroon

De overheid ging planmatiger sturen met doorzettingsmacht

\section{Ontwikkelen van provinciale ruimtelijke kaders}

De provincie kan in haar ruimtelijk beleid eisen stellen aan ontwikkelingen. Nu stuurt ze daarbij vooral op ruimtelijke kwaliteit. Daarnaast kan via ruimtelijk beleid worden gestuurd op de vereiste condities voor energie- en voedselproductie, zoals een provinciaal energienetwerk ten behoeve van grootschalige energieopwekking of aangewezen locaties rondom steden voor ontwikkeling van grootschalige agrofoodparken. Hiertoe kan de provincie ook het instrument van landinrichting en gebiedsontwikkeling inzetten. Zo schept de provincie duidelijkheid voor de lange termijn. Dit biedt voor private partijen ruimte om te kunnen investeren.

\section{Experimenteren met publiek-private samenwerking}

Hoewel de regie sterk bij de overheid komt te liggen, moet het bedrijfsleven bij de grote veranderopgaven in het landelijk gebied betrokken worden. Voor een succesvolle publiek-private samenwerking is het nodig dat de overheid investeert in haar maatschappelijke partners en is een gelijkwaardige relatie nodig, zodat bijvoorbeeld risico's gedeeld worden. Gezien de grote omvang van de opgaven zijn daar misschien nieuwe modellen voor nodig. Bijvoorbeeld om ervoor te zorgen dat milieu- en gezondheidskosten via belastingen of true pricing van producten worden meegewogen in het economisch beleid. Via een lerende aanpak kan de provincie samen met het bedrijfsleven ontdekken welke bestuurs- en organisatiemodellen goed werken. Dit vraagt ook samenwerking met andere overheden. De provincie kan experimenteren met het belonen en waarderen van ondernemers die op de goede weg zijn, door bijvoorbeeld een publieksprijs. Een voorbeeld hiervan is de Groene Twinkeling die jaarlijks wordt uitgereikt door milieu- en natuurorganisaties in Overijssel.

\section{Analyse hoe risico's kunnen worden opgevangen verplicht stellen}

Er zijn grenzen aan technische maakbaarheid. De provincie kan op het moment dat in een gebiedsproces een technische oplossing wordt gekozen, een risicoanalyse uitvoeren. Op basis van de uitkomsten kan zij buffers inbouwen of terugvalopties ontwikkelen.

\section{Inhoud}

Introductie

Vier toekomstperspectieven

Handelingsopties

1 Marktgedreven Overijssel

2 Samenwerkend Overijssel

3 Geregeld Overijssel

4 Natuurgestuurd Overijssel

Handreiking

Vergelijking toekomstperspectieven

Colofon
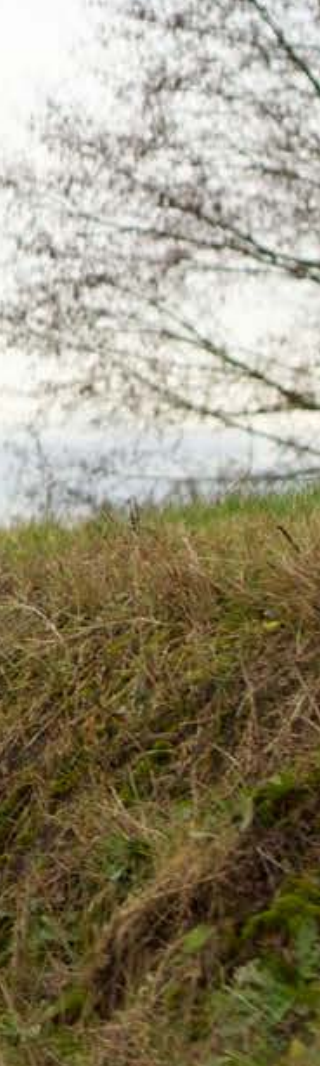

$x+3$

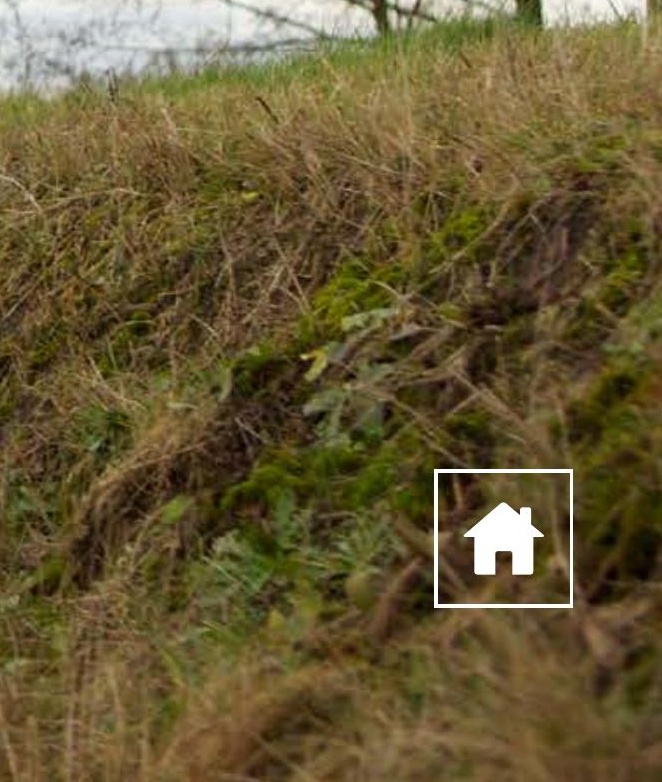




\section{Natuurgestuurd Overijssel}

\section{Welke stappen zijn gezet als het toekomstperspectief is gerealiseerd?}

In Natuurgestuurd Overijssel werken bedrijven, inwoners en overheden in harmonie met de natuurlijke omstandigheden. Natuur en biodiversiteit botsen niet langer met (economische) activiteiten, maar zijn daar juist onderdeel van. Economische ontwikkeling en bescherming en ontwikkeling van natuur en landschap gaan hand in hand. Hoewel er bij de overheid en bedrijven steeds meer interesse is in deze natuurinclusieve manier van omgaan met hun omgeving, zijn er vergeleken met de huidige manier van werken koersveranderingen nodig. De volgende stappen (en tussenstappen) zijn gezet als het toekomstperspectief is gerealiseerd:

Het landgebruik is aangepast aan het natuurlijk systeem In de huidige situatie zijn overheden, inwoners en (agrarische) bedrijven gewend om op het natuurlijk systeem in te grijpen om het land optimaal te gebruiken. In Natuurgestuurd Overijssel zijn ingrepen in de fysieke ondergrond, het watersysteem en het biotische systeem tot het minimum beperkt. De natuurlijke omstandigheden en processen staan juist meer centraal als onderdeel van de bedrijfsvoering. Dat betekent bijvoorbeeld dat veengebieden niet meer worden ontwaterd, natuurlijke processen in beken en rivieren zijn hersteld en dat de bodem op natuurlijke wijze vruchtbaar blijft. Afhankelijk van de kenmerken van het natuurlijk systeem gaat het landgebruik er anders uitzien.

We zien een aantal tussenstappen die hier aan vooraf gingen:

\section{Er ontstond inzicht in de werking van het natuurlijk systeem} in relatie tot menselijk gebruik

Het huidige natuurlijke systeem is ontstaan vanuit een eeuwenlange wisselwerking tussen natuurlijke processen en menselijk gebruik. Deze interactie blijft ook in de toekomst bestaan. Wat verandert is dat we meer ruimte geven aan natuurlijke processen. We gaan hiervoor op zoek naar een nieuwe balans en nieuwe grenzen voor menselijk gebruik en ingrijpen. Die balans kan verschillen per gebied in Overijssel. Er is inzicht in deze regionale systemen nodig om te kunnen bepalen hoe overheden, inwoners en (agrarische) bedrijven kunnen functioneren in harmonie met dat natuurlijke systeem.

\section{Er werd overgangsbeleid voor natuur ontwikkeld}

Het natuurbeheer in 2050 is meer gericht op natuurlijke processen en minder op soortenbeheer. De ambitie voor biodiversiteit blijft gelijk of wordt groter, maar de aanpak is anders. Natuur heeft meer ruimte gekregen om de biodiversiteit te vergroten door natuurlijke processen te herstellen. En om tot een veerkrachtig systeem te komen dat de weerextremen als gevolg van klimaatverandering op kan vangen.

Een strikte interpretatie van de Natuurwetgeving en de Vogel- en Habitatrichtlijn, gericht op instandhouding van internationaal beschermde natuurwaarden op specifieke plekken, kan de overgang naar het natuurlijke systeem belemmeren. Een aantal soorten zou kunnen verdwijnen, terwijl andere daarvoor in de plaats komen. Uiteindelijk levert de aanpak biodiversiteitswinst op, maar in de overgangsperiode treden verschuivingen op die effect hebben op internationaal beschermde natuurwaarden. Dat vraagt een andere benadering van natuurbescherming en nieuwe afspraken met de Europese commissie.

\section{Er werd geïnvesteerd in draagvlak en aanpassingsvermogen} functies

Bewoners en bedrijven kunnen zich verzetten tegen meer ruimte voor natuurlijke processen, omdat ze de bestaande natuurtypen willen behouden of bang zijn voor de mogelijke negatieve effecten, zoals bijvoorbeeld wildschade of muggenoverlast. Ook functies als landbouw, recreatie(vaart) en wonen moeten zich aanpassen. In 2050 is er draagvlak voor het natuurlijk systeem gecreëerd bij bewoners en bedrijven. Ze kennen de achterliggende redenen, zien de voordelen en profiteren hiervan.

Er zijn inkomsten voor aangepast landgebruik ontstaan Het huidige economische systeem is niet goed passend om de omslag naar bescherming en ontwikkeling van natuur en landschap kunnen maken. De huidige rendementen van bijvoorbeeld het agrarisch landgebruik kunnen afnemen en toekomstbestendige alternatieven voor verdienmodellen ontbreken deels nog. In Natuurgestuurd Overijssel worden nieuwe inkomsten gegenereerd met een
1 Marktgedreven Overijssel

2 Samenwerkend Overijssel

3 Geregeld Overijssel

4 Natuurgestuurd Overijssel

Handreiking

Vergelijking toekomstperspectieven Colofon

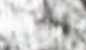

$+\infty \sin ^{2}$
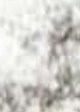

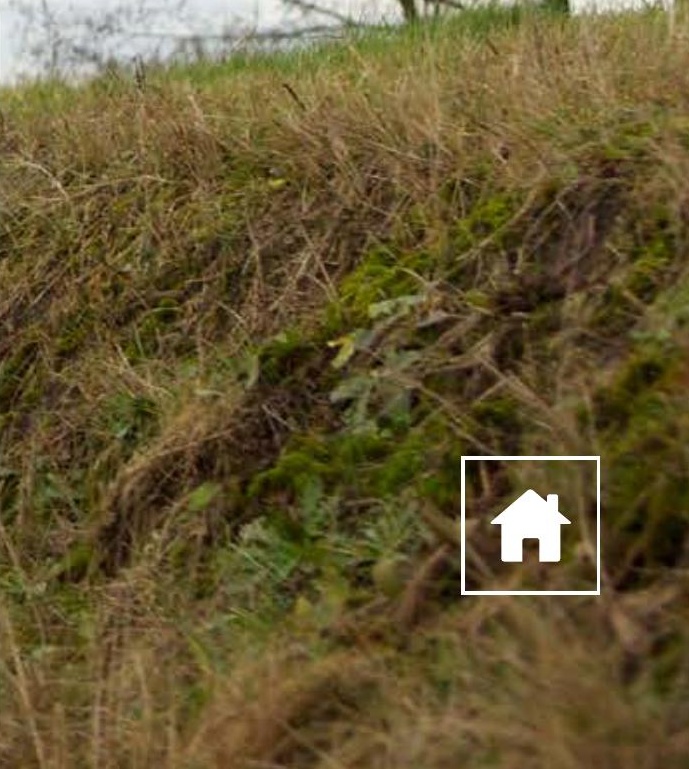


duurzaam landgebruik dat zich heeft aangepast aan de natuurlijke omstandigheden.

We zien een aantal tussenstappen die hier aan vooraf gingen:

Kosten huidig landgebruik werden afgewogen tegen baten van het natuurlijk systeem schap in aanpassingen van het natuurlijk systeem, zoals het droog houden van polders, of het kunstmatig verhogen van grondwaterstanden in natuurgebieden. Deze (private) baten brengen hoge (publieke) kosten met zich mee. Het natuurlijk systeem levert dus besparingen op van publieke kosten en zorgt voor nieuwe baten dankzij diensten die het natuurlijk systeem levert. Als dit toekomstperspectief is gerealiseerd, zijn de besparingen op de publieke

kosten gebruikt om de transitie mogelijk te maken en om schade en inkomstenderving van (private) eigenaren te vergoeden.

\section{Er zijn meervoudige inkomsten voor landgebruik} gegenereerd

In de huidige situatie wordt de grond in het landelijk gebied doorgaans voor één functie gebruikt waarbij de opbrengsten vaak naar één eigenaar of gebruiker gaan. Als dit toekomstperspectief is gerealiseerd heeft de grondgebruiker de omslag gemaakt naar meervoudige inkomsten uit verschillende producten en diensten die voortkomen uit het landgebruik, zonder nadelige effecten voor het natuurlijk systeem. Het inkomen van de grondgebruiker is daarmee minder afhankelijk geworden van één product, risico's worden
In de huidige situatie investeren overheden als provincie en water-

gespreid en toekomstzekerheid blijft gewaarborgd. Agrariërs verbreden het inkomen met bijvoorbeeld opbrengsten uit duurzame energieopwekking en agrarisch natuur-, water- en landschapsbeheer. Terreinbeheerders betalen natuurbeheer met onder andere opbrengsten uit recreatie, opbrengsten uit natuur (hout, riet, voedsel) en duurzame energieopwekking.

\section{Baten van landgebruik werden ingezet om maatschappelijke} diensten te vergoeden

De kosten en de baten van het landgebruik zijn in de huidige situatie niet eerlijk verdeeld. Landgoederen, agrariërs en terreinbeheerders zorgen voor een mooi landschap en aantrekkelijke natuur, dat recreanten trekt waarmee recreatieondernemers verdienen, zonder dat ze bijdragen aan de kosten voor natuur- en landschapsbeheer. Ook voor andere maatschappelijk diensten als voldoende schoon water en opslag van koolstof in de bodem zijn kosten en baten ongelijk over partijen verdeeld.

Om het toekomstperspectief te realiseren is een omslag nodig in het denken over maatschappelijke diensten. Degenen die deze diensten leveren moeten daarvoor beloond worden met een aantrekkelijke vergoeding. Kosten en baten van het landgebruik worden aan elkaar gekoppeld. De financiële constructies die hiervoor nodig zijn, bestaan op dit moment niet of nauwelijks. Ze moeten dus ontwikkeld worden om tot dit perspectief te komen. Als dit toekomstperspectief werkelijkheid is geworden, zijn kosten en baten van het landgebruik aan elkaar gekoppeld.

\section{Welke handelingsopties voor de provincie leiden we hieruit af?}

Hiervoor beschreven we stappen die gezet zijn als het toekomstperspectief is gerealiseerd. In deze paragraaf beschrijven we per stap welke handelingsopties de provincie op korte termijn heeft.

Het Landgebruik is aangepast aan het natuurlijk systeem

\section{Kennisagenda ten behoeve van functioneren natuurlijk sys-} teem Overijssel ontwikkelen

De eerste stap is om in beeld te brengen hoe het natuurlijk systeem in Overijssel functioneert. Meer inzicht in de werking van regionale natuurlijke systemen maakt het mogelijk te bepalen hoe overheden, inwoners en (agrarische) bedrijven kunnen functioneren in harmonie met het natuurlijk systeem. De provincie kan, samen met andere overheden, maatschappelijke partijen en kennispartners, de kennis over de samenhang tussen bodem, ondergrond, grond- en oppervlaktewatersysteem en potentiële natuurwaarden in relatie tot menselijk gebruik vergroten.

\section{Experimenteren en ontwikkeling regionale kaders}

Een vervolgstap kan zijn om met opgedane inzichten kaders te ontwikkelen voor landgebruik. De karakteristieken van het natuurlijk systeem vormen hiervoor het uitgangspunt. Aangezien Overijssel
1 Marktgedreven Overijssel

2 Samenwerkend Overijssel

3 Geregeld Overijssel

4 Natuurgestuurd Overijssel

Handreiking

Vergelijking toekomstperspectieven Colofon (t)

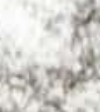

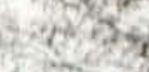
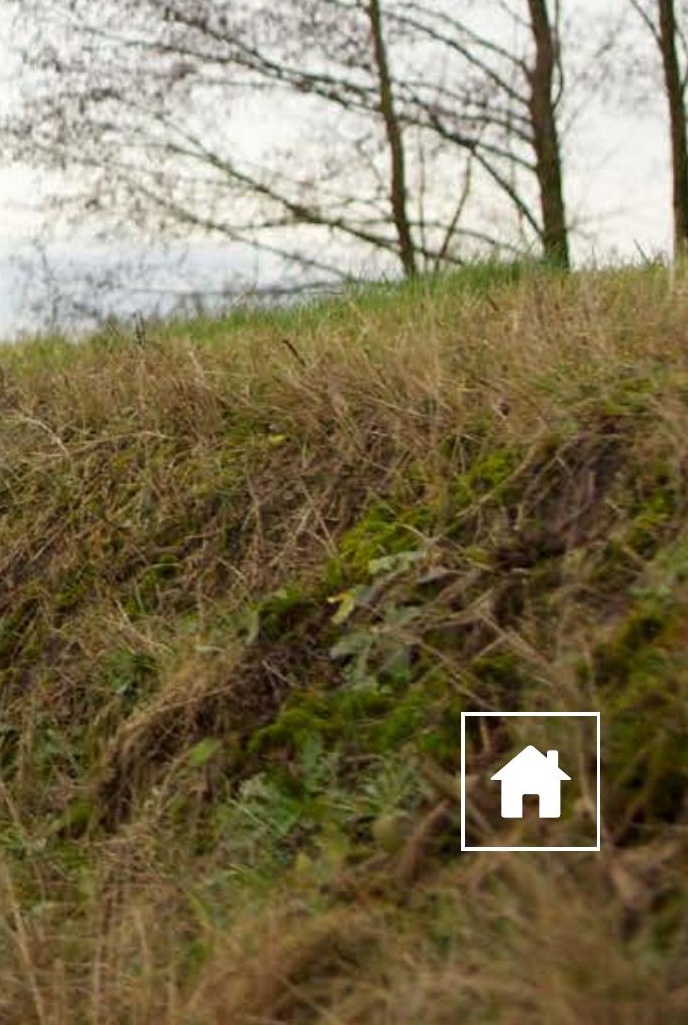
diverse verschillende natuurlijke systemen kent (zoals veen, rivierengebied en dekzandgebied) kan de provincie hiervoor in de verschillende regio's pilots opzetten. Hierin kan zij samen met gebiedspartijen experimenteren met gebiedsspecifieke kaders voor bodem, water en biodiversiteit.

Daarbij moet ook de vraag beantwoord worden in hoeverre de beleidsruimte van de provincie voldoende is om gebiedsgericht te kunnen sturen. Is die ruimte te beperkt, dan kan de provincie in gesprek met het Rijk om bijvoorbeeld experimenteerruimte te krijgen.

\section{Werken op basis van het natuurlijk systeem activeren}

De provincie Overijssel kan in beleid en uitvoering uitgaan van het werken in harmonie met het natuurlijk systeem. Door vroeg in het planproces al aan te sluiten op de natuurlijke omstandigheden, worden later kosten voor beheersing van het natuurlijk systeem voorkomen. Door het goede voorbeeld te geven, kennis te ontwikkelen en ondernemers bij elkaar te brengen, kan de provincie samenwerkingspartners stimuleren dit ook te doen.

\section{In beeld brengen wat het volgen van het natuurlijk systeem} oplevert voor biodiversiteit

De provincie kan als eerste stap in kaart brengen welke biodiversiteitswinst kan worden bereikt als de overgang wordt gemaakt naar het natuurlijk systeem. Deze analyse is op regionale schaal te maken. Op basis van deze analyse is het aannemelijk te maken dat het natuurlijk systeem volgen gunstiger is om de Europese doelen te bereiken.

Overgangsbeleid voor natuur ontwikkelen en afstemmen met Europese Commissie

In overleg met de Europese Commissie kan de provincie een aanpak ontwikkelen om 'ten gunste van' de na te streven situatie het huidige beschermingsregime flexibel toe te passen.

\section{Gebiedsprocessen organiseren}

De provincie kan samen met haar partners gebiedsprocessen organiseren met inbreng van bedrijven, maatschappelijke partijen en bewoners. Hierin kunnen de bezwaren tegen de overgang naar het natuurlijk systeem op tafel komen en worden afgewogen tegen de voordelen die deze overschakeling biedt.

\section{Meervoudige verdienmodellen landgebruik stimuleren en} faciliteren

De provincie kan (agrarische) ondernemingen of andere grondgebruikers helpen om vanuit hun huidige situatie de bedrijfsvoering om te vormen naar een bedrijfsmodel dat draait op meerdere inkomstenbronnen. Een voorbeeld is om landschapsbeheer via de meerwaarde uit producten te financieren en te combineren met recreatie of duurzame energieopwekking. De provincie kan daarvoor een innovatieve test- en ontwikkelomgeving creëren waar ideeën samenkomen en experimenten plaatsvinden. Een actieve rol van de provincie verhoogt de kans dat initiatieven slagen en anderen op tijd aanhaken. Ook kan de provincie het makkelijker maken om financiering te verkrijgen, bijvoorbeeld door ondersteunende regelgeving en door belemmeringen weg te nemen.

\section{Uitvoeren van Maatschappelijke Kosten- en Batenanalyses}

Om de overgang naar werken op basis van het natuurlijk systeem te vergemakkelijken, kan de provincie maatschappelijke kosten- \& batenanalyses (MKBA's) uitvoeren. Hierbij worden de kosten van voortgezet huidig landgebruik afgezet tegen de baten van overschakelen op het natuurlijk systeem. Denk aan vermeden beheerkosten en afname van risico's. Deze MKBA's kunnen voor een specifiek gebied worden uitgevoerd. Denk bijvoorbeeld aan het veenweidegebied of het stroomdal van de Vecht.

\section{Experimenteren met collectieve vergoedingssystemen}

Vergelijkbaar met het zoeken naar meervoudige verdienmodellen kan de provincie ook experimenteren met collectieve vergoedingssystemen voor regiospecifieke maatschappelijke diensten. Voorbeelden zijn het vasthouden van koolstof in bodems, land beschikbaar stellen voor waterberging bij extreme regenval en het beheren van specifieke natuurwaarden. Samen met gebiedspartners en andere overheden kan de provincie experimenteren met een of meerdere vergoedingssystemen en collectieve organisatiestructuren. De uitdaging hierbij is om vergoedingen voor grondgebruikers langdurig te verzekeren. Denk daarbij niet alleen aan de huidige subsidiegeldstromen die beschikbaar zijn voor maatschappelijke diensten, maar ook aan kansen die nieuwe geldstromen kunnen opleveren. $\mathrm{CO}_{2}$-emissierechten of opbrengsten uit duurzame energieopwekking zijn voorbeelden van mogelijke nieuwe geldstromen.

1 Marktgedreven Overijssel

2 Samenwerkend Overijssel

3 Geregeld Overijssel

4 Natuurgestuurd Overijssel

Handreiking

Vergelijking toekomstperspectieven Colofon
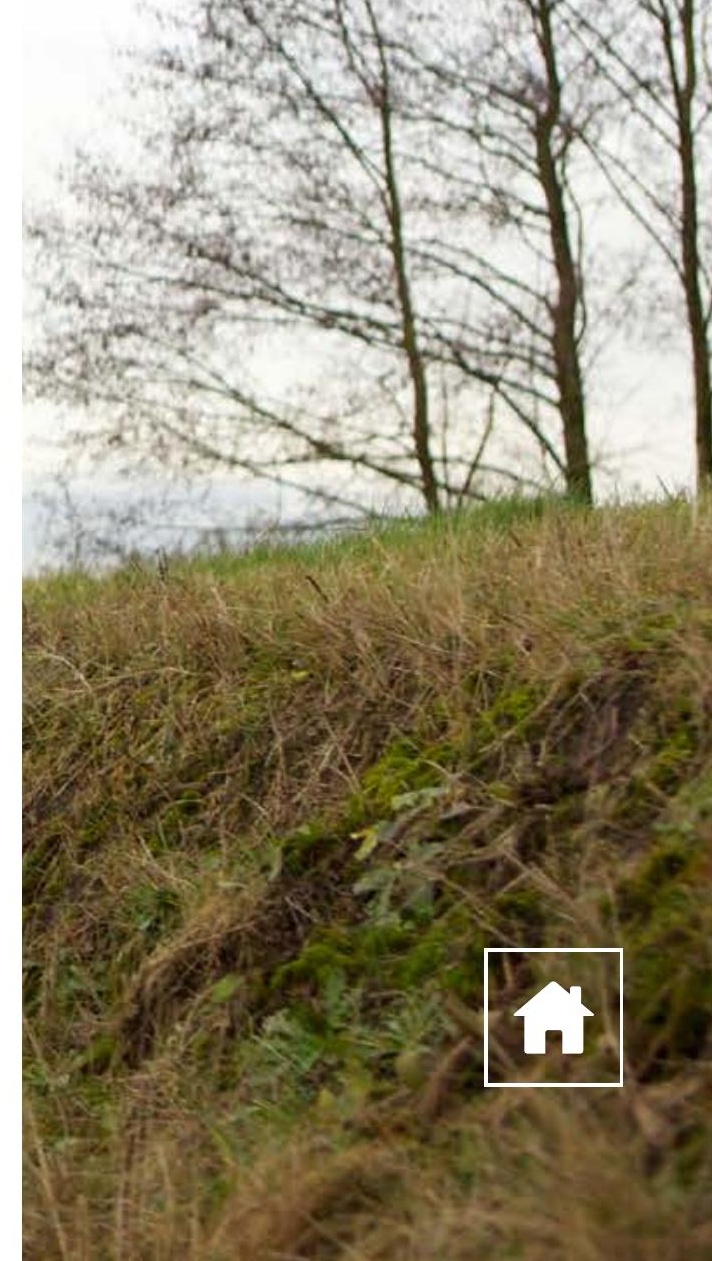


\section{Handreiking: zelf perspectief zoeken voor verduurzaming landelijk gebied}

In deze handreiking lichten we toe hoe de uitkomsten van de Strategieontwikkeling Verduurzaming Landelijk Gebied kunnen worden gebruikt in de praktijk. Niet alleen de vier toekomstperspectieven zijn bruikbaar maar ook de werkwijze waar deze mee zijn ontwikkeld. De handreiking geeft beknopte tips om hier zelf mee aan de slag te gaan.

\section{Toepassingsmogelijkheden}

Er zijn verschillende situaties denkbaar waarin de toekomstperspectieven, de aanpak en de ideeën uit deze strategische verkenning gebruikt kunnen worden. Wij zien de volgende

toepassingsmogelijkheden:

- Koersbepaling voor het Overijssels landelijk gebied. De uitkomsten kunnen worden benut om samen in gesprek te gaan over de gewenste koers voor het landelijk gebied.

- Sectorale opgaven. De resultaten kunnen in sectorale trajecten worden benut om verbinding te zoeken met andere opgaven.

Bijvoorbeeld rond energie, klimaatadaptatie en circulaire economie.

\section{Bepaal je uitgangspunten}

Bepaal de richting waarin je oplossingen gaat zoeken voor een specifiek vraagstuk of een gebiedsontwikkeling door vooraf twee strategische keuzes te maken:

\section{Keuze voor wie het initiatief neemt: de verhouding} samenleving - overheid

- De overheid neemt zelf initiatief en vraagt de samenleving in te vullen. Hierbij stelt de overheid kaders en stuurt ook sterk op de wijze waarop daaraan invulling wordt gegeven.
- Gebiedsprocessen. De resultaten kunnen in gebiedsprocessen worden benut om ontwikkelingsopties te verkennen om zo tot een integrale gezamenlijke gebiedsagenda te komen

De werkwijze waarmee de vier toekomstperspectieven tot stand kwamen, kan vaker worden gebruikt. Deze helpt om verbanden te leggen tussen afzonderlijke sectorale oplossingen en handelingsopties. Op hoofdlijn kunnen de volgende stappen doorlopen worden:

- De overheid stelt kaders, maar vult deze niet zelf in. De samenleving neemt verder initiatief en volbrengt opgaven binnen die kaders.

Keuze voor het type oplossingen: beheersen of volgen van de natuurlijke omstandigheden

- Benut natuurlijke processen en versterk deze door binnen de grenzen van dat systeem te werken. Dit leidt tot een veerkrachtig natuurlijk systeem. Menselijk handelen maakt gebruik van dat systeem zonder de veerkracht aan te tasten.

\section{Inhoud}

Introductie

Vier toekomstperspectieven

Handelingsopties

Handreiking

Vergelijking

toekomstperspectieven

Colofon 
- Ga uit van een technologisch systeem waarbij maakbaarheid het uitgangspunt is. Daarbij staat het (technologisch) beheersen en ingrijpen op het natuurlijk systeem centraal. Als de doelen uit zicht raken, wordt technisch ingegrepen om ze alsnog te halen.
Het maken van deze keuzes helpt om het zoeken naar oplossingen wat meer te richten. In een later stadium kan deze keuze altijd worden bijgesteld om meer en andere oplossingen in beeld te brengen.

\section{Zoek steeds de samenhang tussen verduurzamingsopgaven}

Oplossingen voor sectorale opgaven kunnen bijdragen aan andere opgaven, maar ze kunnen deze ook frustreren. Uit de analyse van de samenhang tussen sectorale verduurzamingsopgaven, kwamen een aantal rode draden naar boven die zijn samengevat in vijf samenhangende opgaven.
Door telkens deze vijf samenhangende opgaven in het oog te houden en te zoeken naar synergie daartussen, kunnen ze elkaar juist versterken en wordt afwenteling voorkomen. Bedenk bijvoorbeeld voor iedere oplossing welke ruimteclaim dit oplevert, hoe dit bijdraagt aan het terugdringen van milieubelastende stoffen en wat het effect is op de regionale economie en de sociale kwaliteit.

\section{Ontwerp een gewenst eindbeeld: welke systeemverandering is nodig?}

De samenhangende opgaven kunnen niet vervuld worden binnen de huidige systemen; daarvoor zijn ze te groot. Daarom onderscheiden we drie systemen waarin innovaties en richtinggevende keuzes nodig zijn om tot duurzame oplossingen voor het landelijk gebied van Overijssel te komen. Dit zijn Landbouw en voedsel, Klimaat en energie en Natuur en biodiversiteit. Als je weet welke verandering je in zo'n systeem voor ogen hebt, kun je ook oplossingen bedenken die daaraan invulling geven. Zo wordt duidelijk hoe je invulling geeft aan de vijf samenhangende opgaven en kun je verbanden leggen tussen die opgaven. Door bij elk vraagstuk na te denken over de doorwerking in deze drie systemen, komen oplossingen voor de opgaven in samenhang tot stand. Op deze manier kun je een gewenst eindbeeld ontwerpen. Het kan ook nodig zijn om even een stap terug te zetten, uitgangspunten bij te stellen of oplossingen weer toetsen aan de samenhangende opgaven.

\section{Werk handelingsopties uit met tussenstappen}

Door vanuit de ontworpen eindsituatie terug te redeneren naar het heden, wordt inzichtelijk welke veranderingen nodig zijn om huidige patronen en structuren te doorbreken. Daaruit kunnen vervolgens handelingsopties worden afgeleid. Deze kunnen in de tijd worden gezet, door de vraag te beantwoorden waarmee je als eerste moet beginnen om de eindsituatie te halen.
Door steeds verbanden te leggen tussen oplossingen, wordt duidelijk hoe zij op elkaar inwerken. Dit maakt het ook mogelijk om bij het uitwerken van tussenstappen padafhankelijkheden in beeld te brengen. Wat zet ik in gang met een keuze die ik vandaag maak? Sluit ik daardoor oplossingsrichtingen uit? Hoe makkelijk is het om op dit besluit terug te komen? En hebben we alle consequenties voor andere opgaven goed in beeld?
Inhoud

Introductie

Vier toekomstperspectieven

Handelingsopties

Handreiking

Vergelijking

toekomstperspectieven

Colofon 


\section{Toepassings- mogelijkheden}

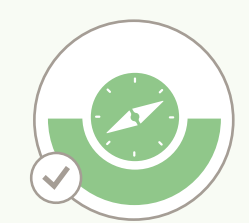

\section{Koersbepaling}

Om richtinggevende keuzes te bepalen.

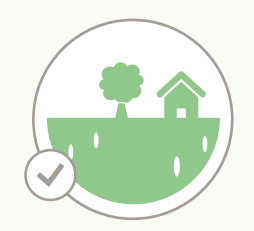

\section{Gebiedsprocessen}

Om tot een brede gebiedsagenda te komen.

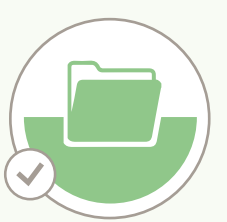

Sectorale processen Om verbinding te zoeken met andere opgaven.

\section{Bepaal uitgangspunten}

- Ga je uit van (benutten van) een veerkrachtig natuurlijk systeem, of van het beheersen via een technologisch systeem?

- Neemt de overheid initiatief en stuurt zij ook sterk op de invulling? Of stelt de overheid alleen kaders en neemt de samenleving verder initiatief en volbrengt opgaven binnen die kaders.

\section{Werkwijze}
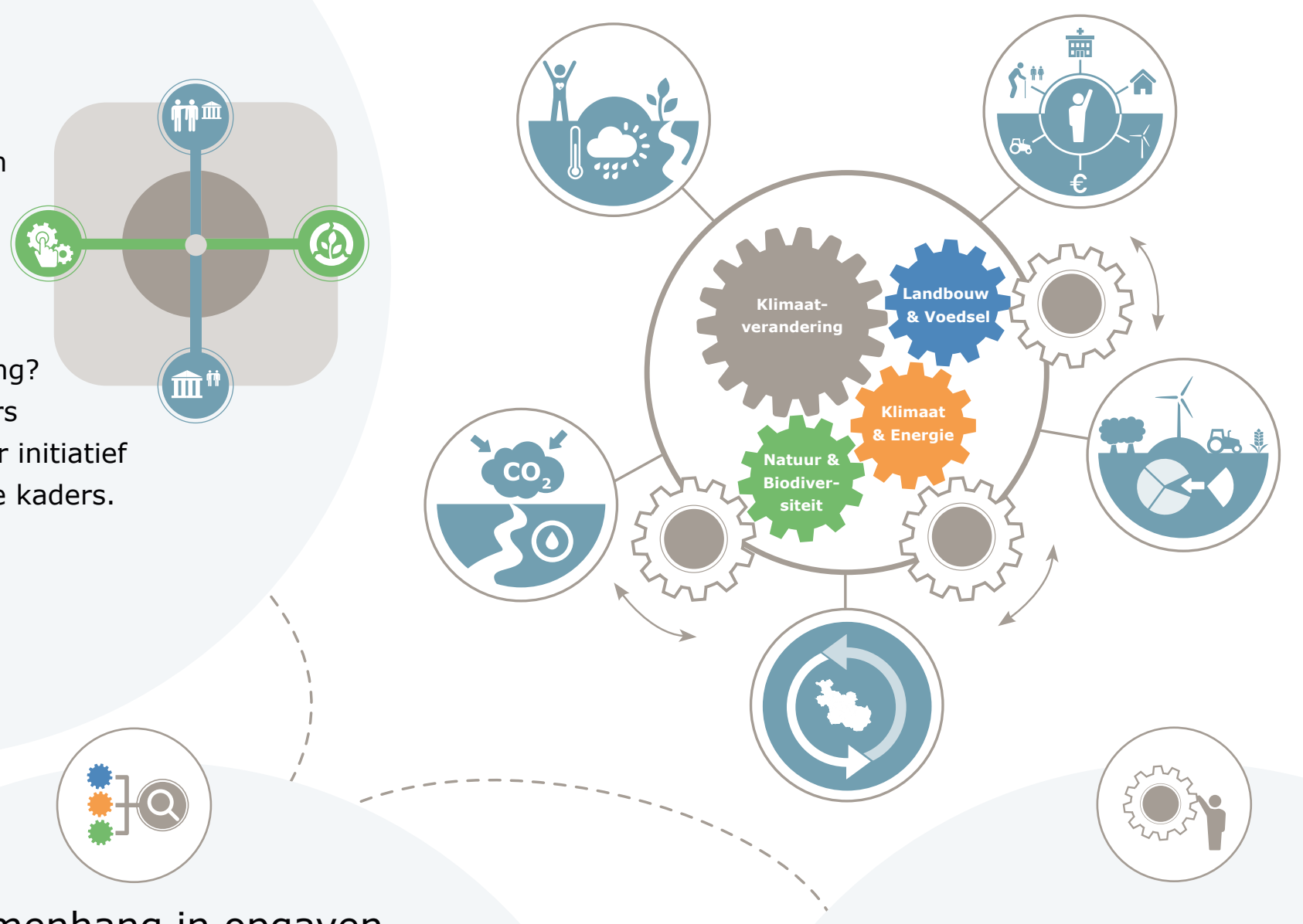

\section{Zoek samenhang in opgaven}

- Welke uitgangspunten hanteer je?

- Beschrijf hoe de drie systeeminnovaties invulling krijgen

- Landbouw \& Voedsel

- Klimaat \& Energie

- Natuur \& Biodiversiteit

- Lost dit de opgaven op?

- Kun je andere opgaven versterken?

- Is er geen sprake van afwenteling?

- Stel eventueel uitgangspunten en invulling systeeminnovaties bij

- Ontwerp je eindbeeld

Breng handelingsopties in beeld

- Wat is het verschil tussen het eindbeeld en nu?

- Welke stappen zijn gezet als het eindbeeld is gerealiseerd?

- Welke handelingsopties leid je hier uit af?

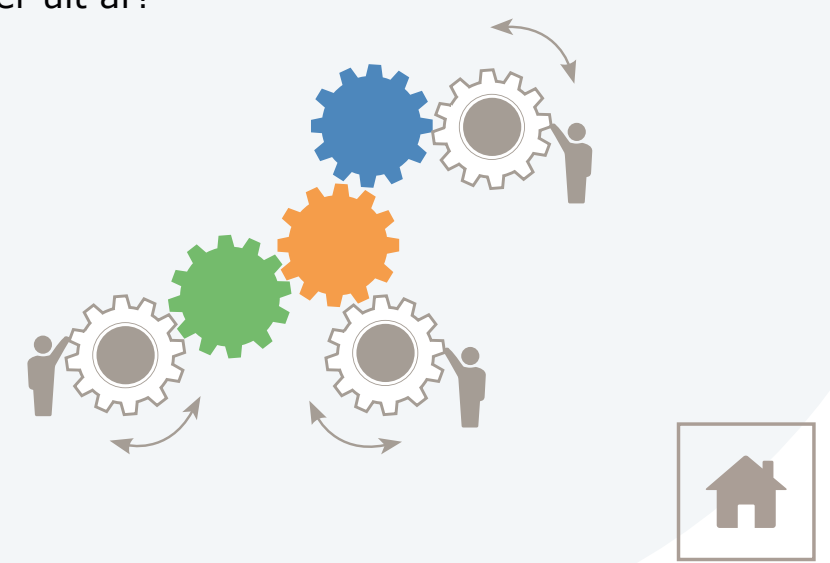




\section{Vergelijking toekomstperspectieven}

Invulling systeeminnovaties en samenhangende opgaven in de toekomstperspectieven

\section{Marktgedreven} Overijsse

Een zelforganiserende

samenleving met

technologisch systeem als uitgangpunt.

Uitgangspunten Bedrijven nemen initiatief. Overheid stelt kaders, faciliteert en stimuleert.

Ontwikkelen met technologie.
Samenwerkend Overijssel

\section{Een zelforganiserende \\ samenleving met het \\ natuurlijke systeem als uitgangspunt.}

Lokale bewoners en bedrijven nemen initiatief.

Overheid stelt kaders, faciliteert

en stimuleert in lokale

netwerken.

Benutten van potenties natuur-

lijk systeem.
Geregeld Overijssel

Natuurgestuurd

Overijssel

\section{Een sturende overheid \\ met technologisch systeem \\ als uitgangpunt. \\ Een sturende overheid \\ met het natuurlijke systeem \\ als uitgangspunt.}

Overheid stelt kaders, reguleert en onderneemt.

Bewoners en bedrijven passen zich aan en vullen in.

Ontwikkelen met technologie.

Overheid stelt kaders, reguleert en neemt initiatief.

Bewoners en bedrijven passen

zich aan en vullen in.

Ontwikkeling binnen grenzen

van natuurlijk systeem.

\section{Systeeminnovaties}

Landbouw en Wereldwijde klimaatneutrale

voedselsysteem voedselketen.

Hightech circulaire systemen voor bulkproductie met nieuwe vormen eiwit.

Huidige landbouwsystemen voor ambachtelijke beleving.

Klimaat en Klimaatneutrale ketens, met

energie compensatie onvermijdbare broeikasgassen.

Kostenefficiënte energie opwekking in private parken daar waar ruimte beschikbaar is Bedrijven en burgers nemen zelf maatregelen tegen wateroverlast en droogte.

Natuur en Natuur waar een markt voor is

biodiversiteit of kan worden gecreëerd? Agrarische biodiversiteit gecombineerd met belevingslandbouw in nieuwe landgoederen.
Lokale productie van eigen voedsel.

Coöperatieve en multifunctionele landbouw gebruik makend van de mogelijkheden van het natuurlijke bodem- en watersysteem.

Gesloten regionale kringlopen begrenzen productie en daarmee broeikasgasemissies.

Lokale energieopwekking voo eigen en stedelijke duurzame energievoorziening.

Lokale natuurlijke oplossingen die weerbaar zijn voor wateroverlast en droogte.

ppontane natuur op basis van natuurlijk systeem, waarbij soorten gaan en komen.

Lokaal gemeenschap werkt samen met natuur.
Gezond en duurzaam voedsel als nutsvoorziening.

Efficiënte voedselproductie onder technologische gecontroleerde omstandigheden.

$\mathrm{CO}_{2}$ belasting; heffing op uitstoot broeikasgassen. Geplande energiehoofdstructuu op overheidsgrond voor duurzame energievoorziening. Overheid neemt (grootschalige) technische maatregelen tegen wateroverlast en droogte.

Gericht op soortenbehoud.

Technische ingrepen om soorte te behouden of herintroductie nieuwe of verdwenen soorten.
Agro-ecologische voedselproductie binnen de grenzen van het natuurlijk systeem en zonder externe input als kunstmest en bestrijdingsmiddelen.

Extensivering grondgebruik levert reductie broeikasgassen. De potentie van de natuurlijke omgeving wordt benut voor duurzame energievoorziening. Robuuste en veerkrachtige natuurlijke systemen die weerbaar zijn voor wateroverlast en droogte.

Robuuste natuur, waarbij

natuurlijke processen de ruimte krijgen.

Natuurinclusieve samenleving waarin zorg voor natuur centraal staat.
Inhoud

Introductie

Vier toekomstperspectieven

Handelingsopties

Handreiking

Vergelijking

toekomstperspectieven

Colofon 
Marktgedreven

Overijssel

Samenwerkend

Overijssel

Een zelforganiserende

samenleving met

technologisch systeem

als uitgangpunt.

Een zelforganiserende

samenleving met het

natuurlijke systeem

als uitgangspunt.

Natuurgestuurd

Overijssel

\section{Een sturende overheid}

met technologisch systeem

als uitgangpunt.

en sturende overheid

met het natuurlijke systeem als uitgangspunt.

Samenhangende opgaven

\section{Emissies}

\section{Circulair en}

zuinig door

Zo min mogelijk grondstoffen per eenheid product en geen verliezen in de keten. Bij een efficiëntere fotosynthese is er minder energie en landbouwgrond nodig voor voedsel.

Omgang met ruimteclaims

\section{Veranderend ruimtegebruik} onder invloed van marktwerking. Ontwikkelaars strijden om grond voor energie. Natuurbeheerders zoeken private investeerders. Indien rendabel worden functies met elkaar gecombineerd.

\section{Transformatie landschappen}

Dynamisch en diffuus landschap bepaalt door marktontwikkelingen.

Ruimtelijke kwaliteit sluit aan bij de wensen van lokale en individuele bewoners.

\section{Sociaal en} economie de consumenten en de wensen
Landbouw past zich aan naar een klimaatneutrale voedselketen in 2050 met inzet van techniek en innovatie. De reductie van andere emissies, zoals stikstof en fosfaat, liften hierin mee.

Lokale productie van eigen voedsel. Leidt tot met meer plantaardige productie en minder veehouderij.

Kringlopen grotendeels lokaa sluiten en natuurlijke productiemiddelen multifunctioneel (her) gebruiken.

Collectief ruimtegebruik door lokale gemeenschap (Marke 2.0). De beschikbare grond wordt multifunctioneel gebruikt wat aansluit bij een natuurlijke bodem- en watersysteem. Landbouwgrond wordt ook gebruikt voor energieproductie,

Grote verscheidenheid land schappen met streekeigen identiteiten.

Ruimtelijke kwaliteit volgt uit handelen lokale gemeenschappen.

Cultuur van noaberschap vormt de basis, mensen helpen elkaar en ontlenen hieraan hun identiteit. van bewoners. Handelen is gericht op license to produce en beïnvloeding publieke opinie. Alternatieve eiwitproductie is een nieuwe economische drage met exportpotentie. Dit geeft goedkoop voedsel dat voor ledereen beschikbaar is.

Een gevarieerde lokale agroen foodeconomie, met nieuwe verdienmodellen voor maatschappelijke initiatief, zoals zelf energie opwekken. recreatie en bosbouw.
Gezonde en duurzame voedselproductie onder technologische gecontroleerde omstandigheden zonder verliezen naar het milieu.

Volledig beheersbaar, efficiënte en ruimtebesparende voedselproductie. De on demand en just in time productie reduceert voedselverspilling.

Via ruimtelijke ordening word planmatig ruimte geschapen voor functies.

Energieproductie in een energiehoofdstructuur. Klimaatadaptatie door slimme waterwerken Natuur in afgeschermde gebieen ingericht voor specifieke soorten

Gepland en maakbaar landschap met sterke scheiding functies. De overheid stuurt op gewenste ruimtelijke kwaliteit, zoals energie clusteren om andere landschappen vrij te houden.

Inwoners worden ontzorgd gezond en duurzaam voedsel, duurzame energie en natuur voor iedereen beschikbaar. Grens tussen tech- en maakindustrie en landbouw vervaagt en is met hightech landbouw internationaal toonaangevend.
Agro-ecologische voedsel-

productie aangepast op mogelijkheden en binnen de grenzen van het natuurlijk systeem.

Leidt tot extensivering

veehouderij.

andbouw met regionale

mineralenkringlopen zonder externe input als kunstmest en bestrijdingsmiddelen.

\section{Grondgebruik past binnen de} grenzen van het natuurlijk systeem. Grenzen tussen tussen landbouw en natuur vervagen.
Halfnatuurlijke landschappen met vermenging van functies Het natuurlijke systeem (bodem, water, reliëf) hanteert de overheid als uitgangspunt voor ruimtelijke kwaliteit.

Natuurlijke omgeving draagt bij aan gezondheid, welzijn en sociale cohesie.

Agrarische bedrijven hebben een meervoudig verdienmodel, o.a. vergoedingen voor verduurzaming en diensten betaald vanuit energieopbrengsten.
Inhoud

Introductie

Vier toekomstperspectieven

Handelingsopties

Handreiking

Vergelijking

toekomstperspectieven

Colofon 


\section{Marktgedreven}

\section{Overijsse}

\section{samenleving met}

technologisch systeem

als uitgangpunt.
Een zelforganiserende
Samenwerkend Overijssel

Een zelforganiserende

samenleving met het

natuurlijke systeem

als uitgangspunt.
Geregeld Overijsse

Een sturende overheid

met technologisch systeem

als uitgangpunt.
Natuurgestuurd

Overijssel

Een sturende overheid

met het natuurlijke systeem als uitgangspunt.

Sturingsmodel en handelingsopties voor overheden

\begin{tabular}{|c|c|c|c|c|}
\hline $\begin{array}{l}\text { Uitgangspunt } \\
\text { sturingsmodel }\end{array}$ & $\begin{array}{l}\text { De overheid gaat uit van de } \\
\text { kracht van de marktwerking. }\end{array}$ & $\begin{array}{l}\text { De overheid gaat uit van de } \\
\text { kracht van zelfsturende lokale } \\
\text { gemeenschappen. }\end{array}$ & $\begin{array}{l}\text { De overheid gaat uit van een } \\
\text { maakbare samenleving. }\end{array}$ & $\begin{array}{l}\text { De overheid gaat uit van de } \\
\text { natuurlijke omstandigheden. }\end{array}$ \\
\hline Uitdagingen & $\begin{array}{l}\text { Zij ondersteunt bedrijven die in } \\
\text { een concurrerende omgeving op } \\
\text { een efficiënt en innovatieve } \\
\text { manier (samen)werken aan het } \\
\text { realiseren van de opgaven. }\end{array}$ & $\begin{array}{l}\text { Zij ondersteunt lokale maat- } \\
\text { schappelijke initiatieven die } \\
\text { werken aan het realiseren van } \\
\text { de opgaven. }\end{array}$ & $\begin{array}{l}\text { Zij neemt de regie in het } \\
\text { realiseren van de opgaven, } \\
\text { middels reguleren, initiatief te } \\
\text { nemen en doorzettingsmacht te } \\
\text { creëren. }\end{array}$ & $\begin{array}{l}\text { Zij stelt gebiedspecifieke kaders } \\
\text { vast voor het realiseren van de } \\
\text { opgaven binnen de grenzen van } \\
\text { het natuurlijke systeem. }\end{array}$ \\
\hline $\begin{array}{l}\text { Handelings- } \\
\text { opties provincie } \\
\text { korte termijn }\end{array}$ & $\begin{array}{l}\text { Inzetten op internationale } \\
\text { afspraken klimaatneutrale } \\
\text { producten. } \\
\text { Duurzame koplopers ondersteu- } \\
\text { nen en als voorbeeld stellen. } \\
\text { Investeren in innovatieklimaat } \\
\text { en creëren van marktkansen } \\
\text { voor baanbrekende oplossingen. } \\
\text { Organisatie van tegenwicht } \\
\text { vanuit de samenleving facilite- } \\
\text { ren om te grote macht bedrijven } \\
\text { te voorkomen. } \\
\text { Experimenteren met publieke } \\
\text { diensten door private partijen. }\end{array}$ & $\begin{array}{l}\text { Maatschappelijke initiatieven } \\
\text { gericht op duurzaam grondge- } \\
\text { bruik toegang tot grond, } \\
\text { kapitaal en kennis geven. } \\
\text { Initiatieven faciliteren bij } \\
\text { verdere opschaling en } \\
\text { professionalisering. } \\
\text { Ontwikkeling korte voedsel- en } \\
\text { ketens ondersteunen. } \\
\text { Kennis delen over werking } \\
\text { natuurlijk systeem. } \\
\text { Experimenteren met het benut- } \\
\text { ten van het natuurlijke systeem } \\
\text { als onderdeel van economisch } \\
\text { beleid. }\end{array}$ & $\begin{array}{l}\text { Kosten en baten van een gezond } \\
\text { en duurzaam voedselsysteem in } \\
\text { beeld brengen. } \\
\text { Ontwikkelen integraal voedsel- } \\
\text { beleid (voedselverspilling, } \\
\text { gezond eetpatroon en duurzame } \\
\text { productie). } \\
\text { Ontwikkelen van ruimtelijke } \\
\text { kaders voor voedsel- en } \\
\text { energieproductie. } \\
\text { Experimenteren met publiek- } \\
\text { private samenwerking. } \\
\text { Inzetten op bewustwording bij } \\
\text { consumenten. } \\
\text { Risicoanalyse uitvoeren en } \\
\text { buffers inbouwen om falen } \\
\text { technische oplossingen op te } \\
\text { kunnen vangen. }\end{array}$ & $\begin{array}{l}\text { Inzicht in van functioneren } \\
\text { natuurlijk systeem. } \\
\text { Overijssel ontwikkelen/ opzetten } \\
\text { kennisagenda. } \\
\text { Kosten en baten van overscha- } \\
\text { keling op natuurlijk systeem in } \\
\text { beeld brengen. } \\
\text { Regionaal experimenteren met } \\
\text { werken op basis van natuurlijk } \\
\text { systeem. } \\
\text { Ontwikkeling van regionale } \\
\text { kaders die grenzen natuurlijk } \\
\text { systeem vaststellen. } \\
\text { Meervoudige verdienmodellen } \\
\text { landgebruik stimuleren. } \\
\text { Experimenteren met collectieve } \\
\text { vergoedingssystemen. }\end{array}$ \\
\hline
\end{tabular}

Inhoud

Introductie

Vier toekomstperspectieven

Handelingsopties

Handreiking

Vergelijking

toekomstperspectieven

Colofon 


\section{Colofon}

\section{Auteurs}

Wageningen Environmental Research: Edo Gies, Wim Nieuwenhuizen,

Michael van Buuren \& Marcel Pleijte

\section{Inhoudelijk gereviewd door}

Gilbert Maas, Jan Peter Lesschen, Raymond Schrijver, Wieger Wamelink,

Judith Westerink, Peter Schipper, Kees Hendriks, onderzoekers van

Wageningen Environmental Research

\section{Akkoord voor publicatie}

Arjan Koomen, teamleider van Regionale Ontwikkeling en Ruimtegebruik

\section{Dankwoord}

De auteurs danken de deelnemers van de ontwerpateliers voor hun bijdrage en Berno Strootman, Hans Peter Benschop, Tim Zwanikken, Bart Buijs, Petra van Egmond \& Gerrit Valkeman en vele anderen voor hun reflectie en input op tussentijdse resultaten.

\section{Deelnemers ontwerpalteliers Organisatie}

Anna Spijkervet

Antje Kingma

Arjan Ausma

Berthe Jongejan

Chris Antuma

Daan Groot

Egbert Jaap Mooiweer

Ellen de Lange

Frank Stroeken

Frans Feil

Frits van der Schans

Gerke Brouwer

Gerrit Meutstege

Hans Hillebrand

Herman van Assen

Hugo Vernhout

Iris Bouwers

Isa Jansen of Lorkeers

Jorrit Kiewik

Lennart Pompe

Maze de Boer

Melle Smets

Merel Enserink

Renske de Man

Rolf Oldejans

Ruben Vermeer

Rudie Freriks

\section{Enschede}

Stichting Innovatie Recreatie en Ruimte

Vreugdehoeve

Landgoed Nijenhuis en Westerflier

Ondernemer gemengd agrarisch bedrijf

Studente Management van de Leefomgeving

Directeur Slow Food Youth Network (SFYN)

Omgevingsmanager Vitens

Beeldend kunstenaar

Conceptueel kunstenaar

Het Oversticht

Stimuland

Groene Metropool Twente/gemeente Enschede

Boswachter

Melkveehouder

\section{Vormgeving}

Wageningen University \& Research, Communication Services

\section{Beeld}

Jam Visual Thinking

L. Hoogenstein

\section{Wageningen Environmental Research, maart 2019}

ISBN: 978-94-6343-419-5

DOI: https://doi.org/10.18174/469158

\section{Contact}

Edo Gies (Wageningen Environmental Research) | edo.gies@wur.nl T 0317481933

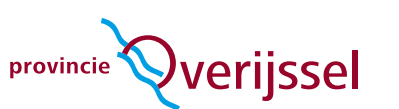

Dit project is uitgevoerd in opdracht van provincie Overijssel en in samenwerking met R. Messelink \& D. de Jong van de provincie Overijssel.

Nieuwsgierig geworden na het lezen van deze brochure? Lees dan het uitgebreidere rapport 'Verduurzaming landelijk gebied Overijssel: Analyse van doelbereik en samenhangende opgaven richting 2050' daarin worden de achtergronden van het onderzoek naar samenhangende opgaven voor Overijssel beschreven.

\section{Copyright}

C) 2019 Wageningen University \& Research

Overname, verveelvoudiging of openbaarmaking van deze uitgave is toegestaan mits met duidelijke bronvermelding.

Overname, verveelvoudiging of openbaarmaking is niet toegestaan voor commerciële doeleinden en/of geldelijk gewin.

Overname, verveelvoudiging of openbaarmaking is niet toegestaan voor die gedeelten van deze uitgave waarvan duidelijk is dat de auteursrechten liggen bij derden en/of zijn voorbehouden.

\section{Aansprakelijkheid}

Wageningen University \& Research aanvaardt geen aansprakelijkheid voor eventuele schade voortvloeiend uit het gebruik van de resultaten van dit onderzoek of de toepassing van de adviezen.
Inhoud

Introductie

Vier toekomstperspectieven

Handelingsopties

Handreiking

Vergelijking

toekomstperspectieven

\section{Colofon}

